This dissertation has been 62-6511

microfilmed exactly as received

DE BRUIN, Hendrik Cornelis, 1929-

STATE REGULATION OF LOCAL SCHOOL DISTRICT FINANCLAL ADIMINISTRATION.

University of Arizona, Ph.D., 1962

Education, administration

University Microfilms, Inc., Ann Arbor, Michigan 
STATE REGULATION OF LOCAL SCHOUL DISTRICT

FINANCIAL ADMINISTRATION

by

Hendrik C. de Bruin

A Dissertation Submitted to the Faculty of the COLLEGE OF EDUCATION

In Partial Fulfillment of the Requirements For the Degree of

DOCTOR OF PHILOSOPHY

In the Graduate College

THE UNIVERSITY OF ARIZONA

1962 
THE UNIVERSITY OF ARIZONA

GRADUATE COLLEGE

I hereby recommend that this dissertation prepared under my direction by Hendrik C. de Bruin

entitled state Regulation of Local jchool District

Financial Administration

be accepted as fulfilling the dissertation requirement of the degree of Doctor of Philosophy

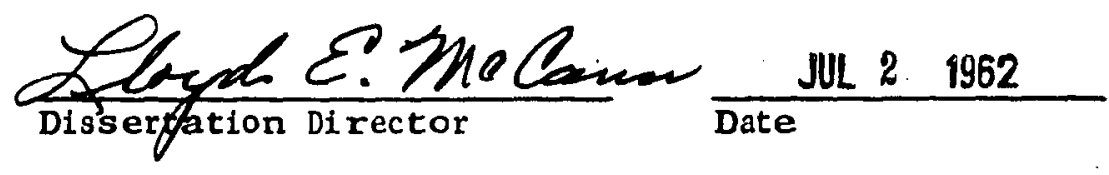

After inspection of the dissertation, the following members of the Final Examination Committee concur in $i$ ts approval and recommend its acceptance:*

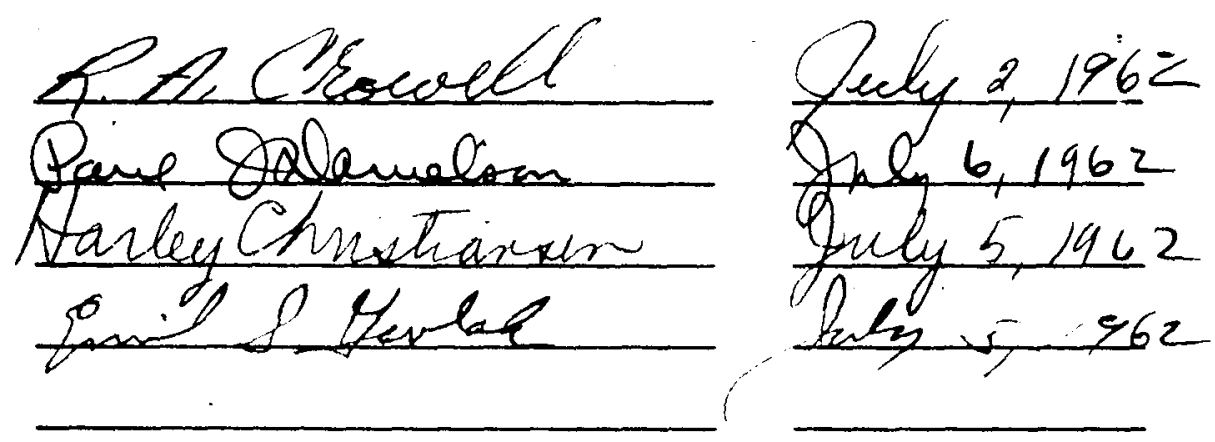

*This approval and acceptance is contingent on the candidate's adequate performance and defense of this dissertation at the final oral examination. The inclusion of this sheet bound into the library copy of the dissertation is evidence of satisfactory performance at the final examination. 


\section{STATEINENT BY AUTHOR}

This dissertation has been submitted in partial fulfillment of requirements for an advanced degree at The University of Arizona and is deposited in The University Library to be made available to borrowers under rules of the Library.

Brief quotations from this dissertation are allowable without special permission, provided that accurate acknowledgment of source is made. Requests for permission for extended quotation from or reprociaction of this manuscript in whole or in part may be granted by the head of the major departinent or the Dean of the iraduate College when in their judgment the proposed use of the material is in the interests of scholarship. In all other instances, however, permission must be obtained from the author.

\section{SIGNED: Bendrith Q de Breure}




\section{ACKNOWLEDGMENTS}

The writer wishes to express his appreciation and gratitude to all persons who have made the completion of this study possible. He is especially indebted to his dissertation adviser, Lr. Lloyd i. ircCann, for his encouragement and guidance during the progress of this study, and to Dean Hollis $\dot{H}$. Moore, Jr. for making the research undertaken possible. Appreciation is due also to the members of the author's comittee: to Dr. Robert Crowell for his continued interest in the author's professional advancement; to Dr. O.K. Garretson for many words oi encouragement; to Dr. Emil Gavlak and Dr. Paul Danielson for their cooperation and understanding. The author is also grateful to Wr. Thomas J. Tormey, Librarian at the College of Law, University of Arizona, for his assistance and advice in carrying out the legal research upon which much of this study is based. A special expression of appreciation is due the author's wife, wrs. viarie de Bruin, and daughter Mari for their constant patience and understanding. 
TABLE OF CONTENTS

CHAPTER

PAGE

I. STATE CONTROL OF LOCAL SCHOOL DISTRICT

FINANCES ................. I 1

Statement of the Problem .......... 1

Origin of the Problem ......... 2

Need for the Problem . . . . . . . 2

Research Procedures . . . . . . . 7

Treatment of the Data ......... 8

II. THE RELATED LITERATURE . . . . . . . . . 9

Fiscal Controls Over Local School District Financial Operations . . . . . . . . . 9

The Legal Basis of School District Financial Operations.............. 22

Surnmary . . . . . . . . . . 29

III. PRESCRIBED ACCUUNTIING FORINS AIND PROCADURAS . • 30

The General Body of the Law ... . . . . . 31

Prescription of Aiccounting Forms . . . . 33

Budgetary Forms and Procedures.... . . 40

Audit Forms and Procedures......... 61

Sunmary . . . . . . . . . . . 78

IV. THE CONSTRUCtion OF SCHOUL BUILdiNGS . . • . 81

Statutory Provisions Governing the Approval

of Plans and Specifications for School

Construction ........... 82

Approval of Building Plans in Relation to

Eligibility for Special State Aid for

School Construction ......... 100

Summary ............... 106 
V. SCHOOL BONDS, SHORT-TERM DEBTS, AND THE

INVESTINENT OF SURPLUS FUNDS . . . . . . 109

The General Body of the Law . . . . . . 111

School Bonds: Long-Terin Obligations..... 113

Short-Term Loans . . . . . . . . 128

Investment of School District Funds . . . . 144

Summary . . . . . . . . . . 152

VI. SCHOOI DISTRICT AUXILIARY AGEIVCIES . . . . 156

The General Body of the Law . . . . . . 157

Student Activity Accounts . . . . . . 158

School Cafeterias .......... 165

Textbooks ............. 172

The Transportation of Pupils . . . . . 183

Summary . . . . . . . . . . 192

VII. SUIMARY AND CONCLUSIONS . . . . . . . . 195

Scope of the Study . . . . . . . 196

Procedures of Research ......... 196

General Conclusions . . . . . . . . 197

BIBLIOGRAPHY . . . . . . . . . . . 200

APPENDIX: TABLE OF CASES CITED . . . . . . . . 207 


\section{LIST OF TABLES}

TABLE

PAGE

I. Statutory Provisions Governing the Prescription of Local School District Financial Accounting Forms . . . . . 36

II. Summary of Statutory Provisions for Uniform School District Financial Accounting Systems

III. Statutory Provisions Governing the Approval of Local School District Budgets . . . . 45

IV. Sumnary of Statutory Provisions Governing the Approval of Local School District Budgets . 51

V. Statutory Provisions for Auditing Local School District Financial Accounts . . . 66

VI. Summary of Statutory Provisions on the Auditing of Local School District Financial Accounts............. 71

VII. Statutory Provisions Governing the Approval of Building Plans and Specifications for School Construction . . . . . . . .

VIII. Summary of Statutory Provisions Governing the Approval of Plans and Specifications for Local School Building Construction . . . 86

IX. State Agencies Having Building Regulations or Inspections for All or Part of the School Districts Within the States . . . . .

X. Summary of Statutory Provisions Governing the Prescription of Building Regulations Applicable to Local School Construction . . . . 92

XI. State Agencies Approving Plans in Order to Qualify for State Construction Aid . . . 101

XII. Statutory Provisions of states Requiring State Agency Approval of Long-Term Bonds . . 116 
TABLE

PAGE

XIII. Statutory Provisions Governing General

Obligation Bond Conditions . . . . . . 119

XIV. Sunmary of Statutory Provisions Governing

School District Bonds ......... 121

XV. Statutory Provisions Governing Short-Term

Loan Procedures . . . . . . . . 132

XVI. Statutory Provisions Governing the Type and Use of Short-Term Loans . . . . . 138

XVII. Statutory Provisions Governing the Approval of Investment of School Funds by School

Districts ............ 146

XVIII. Statutory Provisions Governing the Type and Amount of School District Investments

Permitted ............. 149

XIX. Statutory Provisions Governing School

District Activity Accounts in States

Imposing Statutory Regulation....... 162

XX. Statutory Provisions Governing School Lunch Accounts .............. 167

XXI. Statutory Provisions Governing Textbooks . . 174

XXII. Statutory Provisions of the 28 States Prescribing a Uniform Series of Textbooks . . 179

XXIII. Statutory Provisions Governing the

Transportation of Pupils . . . . . . 186 


\section{CHAPTER I}

STATE CONTROL OF LOCAL SCHOUL DISTRICT FINANCES

With increased participation of the state government in the financing of education, professional educators have been concerned with the control of education exercised by state levels of government. Discussion of increased state participation has uncovered the confusion surrounding the role played by the state in the control of school district financial operations. There is limited evidence regarding the extent of the controls exercised by governmental agencies in the fifty states.

\section{STATEMENT OF THE PROBLEM}

This investigation examines the scope of state financial controls exercised by the fifty states over the operation of local school district financial affairs. The study has been concerned with the following questions:

1. What are the actual controls exercised by state agencies over the operation of local school district financial matters?

2. How have the courts interpreted controls where conflict between state and local agencies has resulted in litigation?

3. What generalizations can be drawn from the statutes, rules and regulations of state agencies, and court decisions relating to them which will help in obtaining an accurate picture of these controls? 


\section{ORIGIN OF THE PROBLEMI}

The recognition of this problem grew out of practical experiences in the financial administration of schools and investigation of educational literature dealing with the subject. From these a realization developed thct:

1. Public education is a function of the states. It is controlled by a number of different governmental agencies authorizəd by the state legislatures to administer aspects of public school operation.

2. State controls are extensive and varied within the several states and upon local districts. A real need exists for careful examination of the scope of these controls.

3. The increasing participation on the part of both the state and federal government in supporting public education within recent years has resulted in increased regulation.

NEED FOR THE PROBLE:

In the early stazes of public school development in the United States, school systems were consiciered local enterprises controlled and financed by the local taxpayers within the school district boundaries. Each local school district was able to operate its schools as it saw fit, provided it operated within the franework of the state constitution and provided it ouserved any statutory stipulations. This local autonomy of school districts was recognized in the work of George D. Strayer, Jr. In 1934, Strayer made a study of the state's responsibility for education in the states of Viaryland, New York, and North Carolina. He stated:

In the early development of education in the United States the locality rather than the state or the 
nation exercised the chief authority. The administration of public education began in the towns, the district, and the township. During the nineteenth century as expenditures and the provisions of educational opportunity continued to increase, it becane evident that small local units of administration were inefficient and costly. The transfer of powers and responsibilities from smaller to larger units of administration was frequently contemporaneous with increased state support for public schools.1

With the increase in state participation in the financing of public education, a great many rules and regulations have been placed on the local school district at the discretion of the state legislature. In the textbook by Miller and Spaulding, ${ }^{2}$ this constant changing of rules and regulations was noted in their statement:

Each local board of education is created by the state through its legislature and may, within the limits of the constitution of the particular state, be given more duties at any time, or have its duties reduced, modified, or changed in any way that the legislature deems wise. It may even be abolished.

The rights and duties of each local board are limited. Unlike an individual who is free to do whatever the law does not forbid, a school board has only (1) those powers specificaliy granted to it, (2) those powers which can be reasonably implied from these specific grants, and (3) those powers essential to carrying out statutory purposes. It cannot do whatever seems good for education in its local district unless it can find the power to do so in one of the above three categories. 3

${ }^{1}$ George D. Strayer, Jr., Centralizing Tendencies in the Administration of Public Education, Teachers College Contributions to Education No. 618 (New York: Teachers College, Columbia University, Bureau of Publications, 1934), p. 2 .

2 Van Miller and Willard B. Spaulding, The Public Administration of American Schools, 2nd edition TNew York: World Book Company, 1958).

I Ibid., p. 111 . 
Many of the rules and regulations exercised by the states in dealing with fiscal controls over local school districts can be found in the statutes, departmental regulations of state agencies, and court decisions relating to them. These controls deal with such items as accounting forms and procedures, budgetary provisions, debt management, and the purchasing of supplies.

Much of the litigation in which school districts are involved is a direct result of these controls. Wayne Soper was aware of this situation when he wrote, "Laws are never so perfect as to prevent misunderstandings of their complete intent and operation. Individuals and groups are never in such complete agreement as to obviate different interpretations of the law. ${ }^{4}$

The question of the allocation of power and controls exercised by various state agencies over the local school district has become more and more complex as the economy of the nation changes. Thurston and Roe, in their textbook State School Administration, 5 commented on this continual change as they wrote, "The question of our changing economy brings to light one of the most absorbing questions in

4Wayne W. Soper, Legal Limitations on the Rights and Powers of School Boards with Respect to Taxation, Teachers College Contributions to Education No. 349 (New York: Teachers College, Columbia University, Bureau of Publications, 1929), p. 1.

${ }^{5}$ Lee $N_{\text {. }}$ Thurston and William H. Roe, State School Administration (New York: Harper and Brothers, 1957). 
school finance, that of the allocation of power among local, state, and national governments. ${ }^{6}$

There continues to be an increasing concern by groups of professional educators over this problem of local school district control by non-educational agencies. At their annual meeting on November 10,1961, the organization of the chief state school officers adopted the following resolution:

The council believes that the time has come to face squarely attempts by non-educational agencies to restructure or otherwise to interfere with the administrative autonomy of state departments of education. If educational leadership is to realize its potential and properly serve our schools and colleges, state departments of education must be strengthened by more adequate professional staffs properly compensated and in a position to exercise independence of action without interference by other governmental agencies. There is an unfortunate trend that tends to restrict and subordinate educational leadership at the state level which ultimately, if allowed to go unchecked, will give rise to similar subordination in local school districts. Advocates of this trend are attempting to promote the placement of educational agencies under other departments of state government such as divisions of finance, civil service, or administration, or under the control of nanagement analysts. Realizing the inherent dangers in this trend, the Council urges legislative bodies and leaders in government to take appropriate action to maintain the educational autonomy upon which the American school system was established.7

The extent of these controls has received the attention of professional educators within recent months. This

$$
{ }^{6} \text { Ibid., p. } 152 .
$$

$7_{\text {Council of Chief State School Officers, Resolutions }}$ and Legislative Policies, Adopted at the annual meeting in Baltimore, Maryland (November 10, 1961). 
is illustrated by a report released on the analysis and evaluation of the New Mexico School Code. It stated in part:

It is ... difficult to determine the number of agents or agencies, which are involved in determining sources, amounts, distribution, budgeting, custody, disbursing, and accounting of school moneys. In addition to the electorate's control through constitutional provision, controls are exercised, among others, by the following:

Attorney general

Chief of public finance

City councils

Commission on youth

County clerks

County commissioners

County tax assessors

County treasurers

Department of finance and administration

Department of public health

Department of public welfare

Director of school lunch

District attorneys

District court clerks

Election judges and clerks

The governor

Law enforcement officers

Legislature

Library extension service

Local boards of education
Local budget commissioners

Local superintendent

Police courts

Political parties

Special interest groups

State auditor

State board of education

State board of finance

State department of personnel

State institutions

State investment officer

State land commission

State library commission

State purchasing agent

State superintendent

State retirement board

State tax collecting agencies

State tax commission

State transportation director

State treasurer
Surplus property agent

This is a list for one state. It contains 41 items.

In other states, additional agencies may be included and some of the above may not exist. However, the list is

${ }^{8}$ Irvin P. Wurphy, A Report to the Legislature, Analysis and Evaluation of the New Mexico School Code (rough draft progress report of a doctoral research project at Teachers College, Columbia University, Santa Fe, New Mexico, November, 1961), p. 153. 
extensive and illustrates the need for the present investigation.

\section{RESEARCH PROCEDURES}

The research procedure of documentary analysis has been employed to examine the scope of state fiscal controls exercised by the 50 states over school district financial operations. The procedure used involved an analysis of three separate sources of materials:

1. The statutes of the 50 states

2. The rules and regulations of state agencies having control over school district financial matters

3. The court decisions in cases related to the problem under consideration.

Standard procedures of legal research were used in locating materials relevant to the specific topics under consideration. Court decisions which seemed to be of major importance have been included in the study to obtain the judicial history of the question in point.

In order to clarify various aspects of special problems being considered, the writer made extensive use of selected secondary sources in addition to those regularly employed. These included textbooks, pamphlets, and other materials related to the areas of school law, school finance, and school administration. This material was helpful in identifying some of the major issues of concern to the study. The secondary sources of major importance have been 
incorporated in the body of the text for comparison with the data collected by the writer. Legal treatises also were examined and included where relevant to the present investigation.

\section{TREATMENT OF THE DATA}

A detailed analysis of the statutory provisions of the areas covered in this investigation appears in the body of the text. The provisions of the several states are presented to identify patterns of similarity, major and minor rules, and individual exceptions.

Court decisions have been analyzed where conflict in the interpretation of statutory provisions has resulted in litigation. The interpretation of statutory provisions by the various courts has been used to determine meaning and application of the statutes of states over the subject matter in question.

By this procedure a picture of the extent of the controls exercised by the various state agencies over local school district financial operations has been drawn in the final chapter. 
CHAPTER II

THE RELATED LITERATURE

A review of the related literature revealed much research and commentary relating to various aspects of the present study. However, none of them cover the exact scope of this study.

In order to have continuity to the materials presented in this chapter, the related literature has been corered under two area headings:

1. The literature concerned with the various aspects of fiscal controls exercised over school district financial operations

2. The literature dealing with the legal basis of school district financial matters.

Because of the nature of the materials presented in this investigation, related literature having a direct bearing on the subject matter under consideration is presented in Chapter III through Chapter VI. This has been done to clarify specific topics under consideration.

FISCAL CONTROLS OVER SCHOOL DISTRICT

FINANCIAL OPERATIONS

From the early days in New England the state governments have been concerned with the financial support of oducation at the local level. 'Local policy for the financial 
support of education became of even greater concern to the state governments as proposals for additional state financial support have increased.

State equalization for the relief of poorer school districts was advocated by Cubberley in 1905. He presented a detailed analysis of the state apportionment picture as it existed at that time. Of special significance to the present study are Cubberley's following conclusions that:

While it may be possible to maintain schools entirely or almost entirely by local taxation, the doing so involves very slight efforts on the part of some communities, and very excessive burdens for other communities, and that progress under such a plan is slow and difficult.

These excessive burdens, borne in large part for the common good, should be in part equalized by the state. To do this some form of general aid is necessary.

Any form of taxation or endowment for schools fails to accomplish the ends for which it was created unless a wide system of distribution is provided.

The present plans for the apportionment of school funds in fully three-fourths of the states of the Union are in need of careful revision, and that there is likewise need for a more careful study of this problem than has been given it so far by most of the states if it is desired that future evolution shall take place along more intelligent lines than has been the case in the past.1

Several years later, Butterworth ${ }^{2}$ cane to similar

I.Ellwood P. Cubberley, School Funds and Their Apportionment, Teachers College contributions to Education No. 2 (New York: : Teachers College, Columbia University, Bureau of Publications, 1905), p. 250.

2 Julian Edward Butterworth, Problems in State High School Finance (New York: World Book Company, 1918). 
conclusions as he discussed the support of the high schools

in the nation.

Paul R. Mort, working with a staff of researchers, completed a study for the U.S. Office of Education in 1933 on the apportionment procedures used in disbursing state school funds. Five of his list of some 35 recommendations have to do with the nature of control and are of importance to the present study. These follow:

The state as a disbursing agency has a very definite interest in safeguarding funds against diversion. There is considerable confusion indicated in state laws between responsibility and the element of controlling the nature of an educational program. Proper safeguarding of expenditures demands an inprovernent of accounting and an extension of auditing practices. Most states either have neglected adequate auditing or have substituted for it one form or another of budgetary control.

Budgetary control involves both safeguarding against diversion of funds and limitation of local initiative. Such control in the long run is opposed to the maintenance of educational efficiency.

The bases for state support developed in this volume are of such a nature that they are independent of the exercise of centralized control by the state. The problom of control should be settled as an independent issue. Plans are proposed for applying penalties for districts failing to meet minimum standards and for earmarking elements of the minimum program at those points where it is desired to introduce control. An inspection of provisions in state support laws now in existence shows that they are fairly free from attempts to control the nature of the educational program.

The most desirable plan for determining the amount of the state's contribution to the support of the educational program is the plan which bases the amount of money which is to be. provided by the state upon set guarantees to individual districts. In order that proper budgetary procedures may be followed in individual districts, such districts must be able to predict with accuracy the amount of funds which they will receive from the state .... 
Care should be taken to avoid introducing elements of control in the basic computations which are made. The elements of control should be the last elements to be considered. Where it is desirable, variations can be made from the logical demands of the principles involved, but this should not be done without a full knowledge of the implications. These implications will be lost if the basic data on which the program is to be based are warped because of the belief that one type of school should be penalized or some reward should be introduced for a special project. 3

These recommendations indicate that the allocation of control should be a late item to be considered in building a state support program; the educational program should be of first concern.

Mort, Reusser, and Polley recently emphasized the need for a thorough evaluation of the scope, adequacy, and emphasis of the role of the state in the educational program. 4

Johns and Morphet listed three criteria that should be used in developing and administering any necessary state regulations in dealing with state support of public schools. 5 They emphasized keeping local control and using state

${ }^{3}$ Paul R. Mort, State Support for Public Education, The National Survey of School Finance, U.S. Department of Interior, U.S. Uffice of Iducation (Washington, D.C.: The American Council on Education, 1933), pp. 3-10.

${ }^{4}$ Paul R. Mort, Walter C. Reusser, and John W. Polley, Public School Finance, 3rd edition (New York: Hilcraw Hill Book Company, 1960), pp. 284-285.

5Roe L. Johns and Edgar L. Morphet, Financing the Public Schools (Englewood Cliffs: Prentice-Hall, Inc., 1960), p. 176. 
support to insure minimum standards of educational opportunity that are universally applicable and which in no way hinder local initiative to go beyond minimum standards. In discussing controls by a central agency they state, "In making decisions regarding control, preference should be given to retaining control locally, particularly for those elements concerning which there is no certainty that the central authority will produce the best long-time results." The desirability of using state control of funds to help attain minimum standards by local school systems has also been emphasized in a textbook by Morphet, Johns, and Reller. ${ }^{6}$ They warn against the adoption of unattainable standards that would become meaningless and could not be reached by the local school. State support should be used only in helping to stimulate local initiative to bring the schools above minimum standards.

Lindman, writing in The American School Board Journal, recently advocated the need for a review of state formulas for the distribution of funcis. He states:

To protect a school budget and be fair to taxpayers, procedures by which property valuations are established for tax purposes must be improved. Formulas by which state funcis are distributed need to be reviewed to be

6edgar L. Morphet, Roe L. Johns, and Theodore L. Reller, Educational Administration (Englewood Cliffs: Prentice-Hali, Inc., 1959), p. 49. 
sure they do not impose undue burdens upon some tax-
payers. 7

The above statement indicates that as recently as 1960 educators recognized the need for an improved tax system and the method of distribution of revenue.

Baughman, writing on the recent law in Arizona which increased the sales tax 50 per cent, warns against the passage of school aid legislation without extensive investigation. He states: "If sone type of school aid legislation is pending in your state, it should be investigated thoroughly before it can be enacted. Even this does not suffice. The glare of publicity is frequently the only preventive for such measures as the one Arizona passed. "8

Miller, ${ }^{9}$ writing at Princeton University, made a critical analysis of existing data on the problem of financing education in the United States. He declared that in too many schools in too many parts of the United States, schools were not being maintained at a level sufficient to meet the standards expected by today's educators, critics, citizen groups, parents, and other interested organizations. Improvement in local education is sought by imposing governmental

7 Erich L. Lindman, "How to Improve the Local and State School Tax Structure," The American jchool Board Journal, CXL (May, 1960), 24.

8 Morris F. Baughman, "Beware False Equalization," The American School Board Journal, CXI (June, 1960), 31 .

9 Ernest Gale Miller, "Financing Public Education in the United States: The Problem of Fiscal Support and Intergovernmental Relations" (unpublished Doctor of Philosophy dissertation, Princeton University, Princeton, N.J., 1959). 
controls at the state level.

In dealing with the problem of control, Miller classified existing state control patterns into three roles which he calls: the operational role, the leadership role, and the regulatory role:

The operational role refers to those activities of state educational agencies involving direct operation. Among a large number of states specific operations include state libraries, museums, schools for exceptional children, teacher placement service, correspondence schools, and the operation of colleges and universities -...

The leadership role refers to those activities of state agencies which are designed to encourage and assist local units in performing their educational tasks, with advice, but no compulsion ....

It is the third role, the regulatory role, that is of primary interest in this study, since it is under this category that state political control over local school units occurs .... The principal regulatory functions exercised in practically all the states are five: (I) the distribution of state school funds, (2) the determination of minimum curriculum requirements, (3) the certification of teachers, (4) the approval of school building plans, and (5) the requirement of local records and reports. A sixth regulatory function potentially important in terins of state influence is the approval and adoption of textbooks, a practice that is given to state agencies in 26 states.10

In summarizing the effect of state control, Willer

writes: "In practice state governments have merely regu-

lated, not operated, the many local educational facilities, and the extent of controls and standards have been minimal. "11

$$
\begin{aligned}
& { }^{10} \text { Ibid., p. } 129 . \\
& { }^{11_{\text {Ibid. }},} \text { p. } 130 .
\end{aligned}
$$


Thurston and Roe, in their book State School Administration, ${ }^{12}$ indicate that as the state participates to a greater degree in the financing of local school districts, there is a tendency to have greater state control. They state:

Along with increased financial aid, both the state and federal government have a natural right to multiply the conditions upon which local school units are eligible to receive their increasing bounties to assure that state and fecieral money is spent wisely. Yet care must be taken to see that local concern and evolvement, the key to our unique educational system in the United States, is not lost. Of course with proper local-state participation and planning it does not necessarily follow that increase in state support means an increase in state controls -- though there is a tendency in that direction.13

$$
\text { Cocking, }{ }^{14} \text { writing in 1957, indicates that a good }
$$

school program is the responsibility of the local, state, and federal governments. He believes this fact should be recognized. He states: "As I see $i t$, the time has come when we must $1 \geqslant \operatorname{cognize}$ that good schools are the concern and responsibility of local, state, and Federal governments. Hence all three governmental levels should participate in the financial support of schools."

Burke ${ }^{15}$ indicates the increased use of the federal

12 Thurston and Roe, op. cit.

13 Ibid., p. 153.

14 Walter D. Cocking, "Can We Adequately Finance Our Schools," The School Executive, LXXVII (October, 1957), 7 .

15 Arvid J. Burke, "Improvement in Educational Quality," The School Executive, LXXIX (November, 1959), 21. 
tax system if states do not help local districts pay for increasing school costs. He states:

If states do not respond to the forces causing higher school costs, the possible consequences are: School quality will deteriorate to an even greater extent; or the rate of increase in taxes will be greater than can be justified economically; or greater use of the federal tax system will be necessary.

Hales does not question whether state control increases with state participation. This is stated as a matter of fact. He tries to explain the increase in state control thus:

The relation between financial aid and control, because it is both immediate and direct, is often accepted as a sufficient explanation of increased state control. A more pertinent question, however, might be, Why was aid extended? It may very well be that aid itself is symptomatic --a manifestation of a deeper and precedent concern created by underlying social and economic changes. It is important to note that increased state control paralleled not only increased state aid, but also industrial development, which was assumed by many to require a more literate public. 16

Harold Groves, writing in Viewpoints on Public Finance, a textbook covering the general area of public finance, recognizes the problem of control when granting aid by the state to a governmental instrumentality. He indicates that controls are necessary, but also warns against too much control. He states:

A certain amount of control will be necessary to insure efficient spending .... On the other hand, the amount of central control imposed may become so great

${ }^{16}$ Dawson Hales, Federal Control of Public Education (New York: Teachers College, Columbia University, Bureau of Publications, 1954), p. 50. 
as to nullify one of the purposes of the use of grants which is to maintain local interest, initiative, and administration.17

Rosentengel and Eastmand, writing in their book School Finance, ${ }^{18}$ place the responsibility for providing a system of checks and balances to insure desirable financial transactions at the local level with the state department of education. This should be done to safeguard the interests of the people of the state.

Knezevich and Fowlkes, ${ }^{19}$ dealing with the proper procedures of school district financial management, feel it desirable to keep a large degree of participation and control at the local level. By keeping education close to the people of the district and using state control to prevent local initiative from degenerating, local support of education will strengthen.

Benson's textbook, The Economics of Public Education, 20 is a theoretical treatment of principles underlying the structure of public school finance. In explaining the reasons why governments help finance a wide range of activities (education being one), Benson writes:

17 Harold iv. Groves, Viewpoints on Public Finance (New York: Henry Holt and Company, 1948), p. 606.

18 William E. Rosententgel and Jefferson N. Eastmond, School Finance (New York: Ronald Press Company, 1957), p. 139.

${ }^{19}$ Stephen J. Knezevich and John G. Fowlkes, Business Manageinent of Local School Systems (New York: Harper and Brothers, $1 9 6 0 \longdiv { , ~ p . ~ } 5$.

20 Charles S. Benson, The Economics of Public Education (Cambridge, Mass.: The Riverside Press, 1961 ). 
For government to undertake to supply a service, it is necessary --presumably-- that two conditions be met: (1) the service is important to the households of the economy, and (2) it will not be supplied in sufficient quantity, or quality, wholly through private financing. The government then uses its powers to tax, to charge fees, and to borrow that the service may be supplied at a more adequate level. 21

In discussing the degree of involvement of the government, Benson indicates that there are two extremes which could be used:

Conceivably, the contribution of government might be limited to finance only .... At the other extreme, it is conceivable that the government would initiate, plan for, and itself completely provide certain services, as well as taking the responsibility for financing them. Generally speaking, the degree of involvement of the government can be considered as lying somewhere between these two extremes.22

An analysis and summary of significant research in the field of school finance was completed in 1952 by a committee of the National Conference of Professors of iducational Administration. 23 of particular importance to the present study is Chapter IX, "Fiscal Controls," by Raleigh w. Holmstelt. In his summary on the control of public school expenditures he states:

The control of expenditures is essentially a function of local administration. Any control device which
$21_{\text {Ib1d., p. } 36 .}$
22 Ibid., p. 37.
23R.L. Johns and E.L. Morphet (eds.), Problems and Issues in Public School Finance (New York: Teachers College, Columbia University, Bureau of Publications, 1952). 
transfers this function to another agency, either state or local, deprives local school administration of the means for effectuating educational policies. There appears to be no operational advantage to local school systems in fiscal dependence. Whatever may be the merits of municipal control of school expenditures from the standpoint of municipal adninistration, there is no evidence that fiscal dependence facilitates the attainment of educational objectives, results in greater economy and efficiency in school management, or is necessary in coordinating and unifying services of mutual concern to the municipality and the school system ....

State requirenents which are too detailed and extensive tend to restrict local discretion and hamper local initiative. If local resources are exhausted in meeting state requirements, there is no leeway for financing local adaptations anci adjustrnents in the educational program. No fiscal control should operate to prevent the local school unit from exceeding the state requirements. The state's objective in economy and efficiency in management can best be attained through professional supervision, advisory services, and technical assistance...

The criteria for evaluating expenditure controls must be found in the effect of the controls on educational policy and educational services. 24

Holmstedt indicates that any state fiscal control

should not operate in such a manner as to hamper local initiative, or from exceeding the state's mininum requirenents for education. The evaluation of state control should be measured by its effect on the state's educational program. James $^{25}$ completed a pilot study on school revenue systems and procedures in five states under the Cooperative Research Program of the Department of Health, Education, and

${ }^{24}$ Ibid., p. 309.

$25 \mathrm{H}$. Thomas James, School Revenue Systems in Five States, Cooperative Research Project ivo. 803 (Washington, D.C.: U.S. Office of Education, Niarch 31, 1961). 
Welfare. The five states included in the investigation were: Washington, California, New Jersey, Wisconsin, and Nebraska. James presented a list of devices used by the states studied in receiving and disbursing school revenues within the states:

An allocation of fixed-unit amounts of revenue drawn from state-wide uniform taxes (usually income or sales taxes or both) and uniformly distributed within the classes of districts.

The yield of a fixed rate of taxation on the property tax base of the district.

An allocation from state-collected taxes of amounts varying in some inverse proportion to the yield of the fixed rate (the equalization program).

A delegation of authority to local districts to levy an additional tax on property above the rate mandated by the state. 26

It is quite evident from the devices listed above that in the states James studied an undue burden is placed on the local property owmer. This study bears out some of the conclusions reached by educators reported earlier in this chapter that a need exists for careful review of school financing programs. James indicates that considerable importance attaches to the decision as to the particular agencies assigned responsibility for supervising the administration of school finance programs. 


\section{THE LEGAL BASIS OF SCHOOL DISTRICT}

FINANCIAL OPERATIONS

From the very beginning of this nation, government has been responsible to a large dejree for the establishment of educational institutions. In early New ingland, towns provided for schools which were operated under the supervision of the town. With the passing of the Massachusetts laws of 1642 and 1647, the government exercised control over the education of youngsters.

Through the years additional legislation has been passed by all states over a variety of educational policies. This section of the related literature is devoted to a review of the materials concerning controls passed by state legislatures over the operation of school district financial affairs. Englehardt and inglehardt discussed the framing of future educational legislation to provide funds for the support of education in Public School Business Adininistration 27 published in 1927. They state, "If the legal controls are to assume a true place in the scheme of things, they must be constantly reviewed in terms of changing situations and new. facts. ${ }^{28}$

27 N.L. Englehardt and Fred Englehardt, Public School Business Administration, (New York: Teachers College, Columbia University, Bureau of Publications, 1927).

$$
28 \text { Ibid., p. } 77 .
$$


The fact that the several state legislatures have plenary power over education and that they can modify, change, or completely remove the schools from local control at will was discussed by Remmlein in The Law of Local Public School Administration. 29

A history of the legal basis of education beginning with the Massachusetts Laws of 1642 and 1647 was treated by Hoehlman. 30

In a discussion of the types of laws found in the states applicable to schools, Carpbell, Corbally, and Ramseyer 31 indicate that they are expressed in four ways: by the Constitution, the statutes, case law, and administrative regulations.

An attempt to evaluate existing school laws was the subject of Remmlein and Ware's book entitled An Evaluation of Existing Forms of School Laws. ${ }^{32}$ This is one of a series

29 Madaline Kinter Remmlein, The Law of Local Public School Administration (New York: McGraw-Hill Book Company, 1953), 12.

30 Arthur B. Moehlman, School Adrinistration, 2nd edition (New York: Houghton Viifflin Company, 1951), pp. 2237.

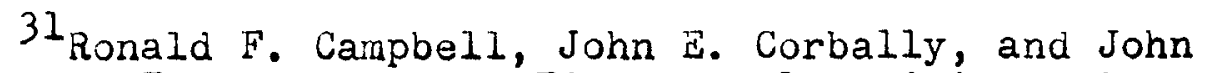
A. Ramseyer, Introduction to Educational Administration (Boston: Allyn and Bacon, Inc., 1958), p. 152.

32 Madaline Kinter Remmlein and Wartha L. Ware, An Evaluation of Existing Foring of School Laws, Sponsored by the National Urganization on Legal Problems in Education (Cincinnati: The W.H. Anderson Company, 19.59). 
of publications sponsored by the National Organization on Legal Problems in Education (NOLPE). In April of 1958 questionnaires were mailed to chief state school officers, officers of state school board associations, members of NOLPE, and to a selected group of persons who hac helped in the revisions of school laws in the various states. The returns of these questionnaires served as a basis for the contents of the book. Suggestions are made for the drafting of a good educational law. This work is helpful to organizations and individuals working toward increased financial support bills to be introduced in state legislatures.

The works of Edwards 33 and Trusler ${ }^{34}$ deal with the legal aspects of the school district, school employees, and actions of the school board. They cover such items as transportation, tuition, school building construction, and other - related school functions. Because of the large number of cases reported in each book (in excess of 1,500 cases in Trusler alone), they serve as a guide in locating court decisions on questions under consideration in the present study.

33 Newton Edwards, The Courts and the Public Schools, revised edition (Chicago: The University of Chicago Press, $1955)$.

${ }^{34}$ Harry Raymond Trusler, Essentials of School Law (Milwaukee: The Bruce Publishing Company, 1927). 
The works by Hamilton and Reutter ${ }^{35}$ and by Hamilton and Mort ${ }^{36}$ are generalized texts covering the legal questions which arise in the operation of a school district. They were of value to the present study in locating cases involving important legal principles in question and in the interpretation of these principles as they were applied by the courts.

In discussing the interpretation of school statutes by the courts through the years, Roach indicates that they have been interpreted liberally. He states:

These time-honored and oft repeated expressions of the views of our American courts have thus, in effect, established a highly significant legal principle: school statutes are to be construed liberally; and substantial compliance with such statutes will ordinarily be acceptable. 37

Throughout this investigation legal principles will be discussed by the writer. It will be of special importance to note if the above liberal interpretation applies to the area of school district financial operations.

35 Robert R. Hamilton and idmund Reutter, Jr., Legal Aspects of jchool Board Operation (New York: Teachers College, Columbia University, Bureau of Publications, 1958).

36 Robert $R$. Hamilton and Paul R. Hort, The Law and Public Education (Brooklyn: The Foundation Press, Inc., 1959).

37 Stephen F. Roach, "Liberal Court Interpretation of School Statutes, $"$ The American School Board Journal, CXXLVIII (April, 1959), 45. 
Roach, in another article, discusses the legal principle applied by the courts where a conflict of interests exists between school districts and municipal governments. he states:

One of the pertinent legal principles invariably applied by the courts in such controversies might be stated as follows: School districts, even though coterminous with municipal boundries, are local governmental units governed by a board of education. is such, they are separate, districts, and free from the control of the municipal governing body except to the extent the education law provides otherwise. 38

In several of the problems under consicieration in this study, municipal governments are responsible for review of actions proposed by school officials. The legal principle proposed by Roach will be reviewed for validation with the data collected by the writer.

The Yearbook of School $\underline{\text { Law }}^{39}$ is a yearly publication started in 1950 by Lee 0. Garber. It deals with the decisions rendered by the higher courts of the nation, both federal and state, reported during a 12-month period that are of special significance to education. A few of the more important decisions are treated in detail. The yearbooks also contain annotated bibliographies of recent research studies

${ }^{38}$ Stephen F. Roach, "Conflicts Between School Districts and Vunicipalities," The American School Board Journal, CXXIIX (July, 1959), 33.

${ }^{39}$ Lee 0. Garber, 1962 Yearbook of jchool Law (Danville: The Interstate Printers and Publishers, Inc., 1962). This is the most recent publication in this series. 
completed in the field of school law. Several issues have sections relating to the control of school district finances. In the 1960 edition, Garber discusses the plenary power of the legislature over school finances by stating: "The state ... is responsible for the maintenance and support of schools. Its authority is plenary, and it may, unless prohibited from doing so by the constitution, enact any type of law it desires relating to school finances." 40

This is another one of the legal principles discussed by professional writers in the school law field; it will be validated with the data collected by the author and presented in subsequent chapters of this study.

Huls, ${ }^{41}$ writing at the University of iinnesota, investigated the legal limitations exercised by state constitutions and statutes over school district indebtedness. He collected the data by questionnaire to the 40 state departments of education and by a search of the applicable statutes. Within the dissertation are tables giving the legal limitations on long-term school indebtedness ${ }^{42}$ and the legal

$40_{\text {Lee }}$ 0. Garber, 1900 Yearbook of School Law (Danville: The Interstate Printers and Publishers, Inc., 1960), p. 87.

${ }^{41}$ Harry k. Huls, "State Limitations on Local Public School Expenditures in the United States" (unpublished Doctor of Philosophy dissertation, University of ivinnesota, vivinneapolis, 1958).

${ }^{42}$ Ibid., pp. $58-60$. 
Iimitations on short-term school indebtedness. 43

Huls concludes thet in formulating legislation regarding school district indebtedness, eight principles should be followed:

Total debt should be limited, rather than warrants and bonds being limited separately ....

The only limit on total expenditures should be a budget voted upon by the people of the school district

Transfers within funds should not be limited ....

Transfers between funds of the budget should not be limited by state law but by board of education only ....

Interest should not be limited as to rate or amount, but should be arrived at through bids ....

Purchases above a set limit should be obtained by bids . ...

Any limitation on expenditures or borrowing should be statutory rather than Constitutional ....

No exceptions should be made to laws limiting expenditures to suit certain districts. But, if exceptions are necessary the entire law should be revised to fit all districts of the state ...44

The eight principles listed by Huls will be of importance to the present study when analyzing statutory provisions dealing with the aproval of school district indebtedness to see if the recommendations are followed by the several states.

Burke, writing in Defensible Spending for Public Schools, ${ }^{45}$ discusses the legal controls exercised by state
43 Ibid., pp. 67-69.
${ }^{44}$ Ibid., pp. 109-115.
45 Arvid J. Burke, Defensible Spending for Public Schools (New York: Columbia University Press, 1943). 
constitutions and statutory provisions over school expenditures during the Second World War. Burke indicates that the demand for control increases as the federal, state, and local governments participate to a greater extent in the f1nancing of public education.

\section{SUMMARY}

The research and commentary reviewed in this chapter cover the materials of major significance to the present study. Materials of importance to specific problems are discussed in the body of the subsequent chapters for comparison with the original there presented. The materials reviewed here are of such general nature that they are basic to the further discussion undertaken in the several sections of this report. 


\section{CHAPTER III}

\section{PRESCRIBED ACCOUNTING FORMS AND PROCEDURES}

The several state legislatures have enacted statutory provisions which prescribe fiscal accounting forms or direct stipulated agencies to prescribe them for use in financial transactions of school districts. These provisions have been enacted to insure proper and efficient use of school district funds. Thus, the use of state-prescribed accounting forms becomes a control exercised by the state over school district financial operations.

The materials contained in this chapter deal with the statutory provisions related to the prescription of fiscal accounting forms and the procedures employed in their use. These provisions are of special significance to the present study in order to answer the following questions:

1. To what extent must school officials comply with statutory provisions governing the use of fiscal accounting forms?

2. What is the role of the state in the prescription and use of fiscal accounting forms?

3. Which of the controls listed in the statutes to be exercised by state agencies are mandatory on the actions of local school officials?

4. How have the courts ruled in cases that have resulted in litigation over the use of prescribed accounting forms and procedures? 
These questions need to be answered to examine the extent of control exercised by state agencies in the prescription and use of accounting forms and procedures.

THE GENERAI BODY OF LAW

The general body of the law governing the use of prescribed forms and procedures is summarized in Corpus Juris Secundum:

In accordance with statutory provisions, the officers having management of school funds are required to make, publish, or file reports or statements of their accounts. Compliance with the requirements of such statutes has been held to be mandatory, so that where detailed particulars are required a statement containing mere general summaries is insufficient ....

The statutes sometimes provicie for the audit and settlement of the accounts of school directors and other district officers before specified auditors, at designated times, and the reports of such audits must comply with statutory prerequisites. The manner of compelling school officers to produce the books and papers necessary for the audit must be followed ....

Failure to file a report as to a particular officer within a designated time does not prevent the filing of such report at a later time. It has been held that, where auditors have completed their report and filed it, they may not make a second audit but they may at any time make such further examination as is necessary in order to complete their report, and that the failure of the auditors to make a yearly audit dops not bar them from subsequently making such audit. 1

Under sone statutes, the school authorities are required to prepare an annual budget or to subinit to the appropriating bodies estimates, requisitions, or

${ }^{1} 79$ C.J.s. Accounts, reports, and statements of officers, par. 345 (1952). 
recommendations of amounts to be expended or needed, and the school budget or estimate when adopted or approved constitutes an appropriation. In preparing or submitting a budget, estimate, requisition, or reconnendation, statutory provisions must be complied with. An estimate or budget at the time of filing is not final and unalterable, but it nay not be changed after it has been adopted or approved.2

In the above statement, compliance with statutory requirements is presented as being mandatory on all districts in states where fiscal accounting forins are prescribed by law. However, this is not always the case. Statutes among the states may be classified as being optional, directory, or mandatory. In some states compliance with statutory regulations must be followed to the letter of the law, regardless of the size or class of school district; such provisions are referred to as mandatory provisions. In other states, statutes have been written so that the action may be directory, that is, the practice should be followed but does not necessarily have to be complied with. Several states have enacted legislation in which the statute is optional, that is, school districts may choose the action prescribed by the legislature or continue under an existing method of operation if it meets the approval of a state agency.

For exainle, in the state of New Jersey the statute is written so that every district is compelled to use a simple and uniforn system of bookkeeping as prescribed by

\section{Ibid., Budget or estimate, par. 343.}


the State Board of Education. In Connecticut the existing system of accounting may be used if it meets the approval of the State Tax Commissioner, and he has the authority to compel the district to comply with the state prescribed system if the existing system does not meet his satisfaction. The accounting system prescribed for the state of Wassachusetts will be installed only by local referendum. This type of control is referred to as optional with the district.

Some statutes have been written so that whether the statute is classified as mandatory, directory, or optional will depend on the class or size of school district. In other words, the statutes themselves have been written for special classes of districts, or for the exclusion of certain districts.

This classification of statutes as mandatory, directory, or optional must be kept in mind when reading the court decisions in which accounting forms have been the subject of litigation, since the courts interpret the statutes in this light.

\section{PRESCRIPTION OF ACCOUNTING FORVIS}

This section is concerned with the statutory provisions governing the prescription and use of fiscal accounting forms by school districts within the 50 states. Specifically, this section deals with: 
1. The statutes that have a prescribed uniform system of accounts

2. The agency responsible for prescribing a uniform system of accounts

3. The degree of compulsion in requiring that specified forms be used by school districts.

For purposes of illustration of the detail of statutory enactments regarding the mandatory use of a prescribed system of accounts, the statutory provisions of the states of New Jersey and Wissouri are presented. Both states leave the prescription of school district accounting forms to the State Board of Education. In New Jersey the applicable statute reads: "Duties of the State Board of Education: Prescribe a uniform and simple system of bookkeeping for use in all school districts, and compel all school districts to use the same. ${ }^{3}$

The language of the above statute indicates that a uniform system of accounting as prescribed by the State Board of Education is to be used by all school districts within the state. The word "compel" in the statutory provision listed above classifies this statute as mandatory. School districts must follow the prescribed system of accounts.

The section of the Missouri statutes that empowers the State Board of Education to prescribe accounting forms 
for school districts reads as follows:

All necessary blanks required by school officers shall be furnished by the state board of education to the county superintendert, who shall immediately, upon receipt of the same, supply the clerk of each district in their respective counties with the same, the form of such blanks to be determined and indicated by the state board of education as provided by law ....4

The language used in the Missouri statute does not say that school districts are compelled to use the forms, or that a penalty for non-conforinance is to be made. Actually, then, the use of a definite prescribed system of accounts becomes directory with the district. This interpretation of the meaning of the various statutes, in absence of court cases clarifying the meaning, is a continuing problem. Table I, presented on the following page, gives an analysis of the state statutes dealing with the prescription of accounting forms in the various states. Each of the 50 states has as part of its statutes some agency or person designated with the responsibility of prescribing a uniform system of accounting that applies to school districts.

In five of the 50 states --namely, Connecticut, Massachusetts, Tennessee, Vermont, and Wisconsin-- the use of a prescribed accounting system is optional with the individual districts within these states. Viassachusetts and Vermont have legislation permitting the local electorate to request

\footnotetext{
"Vernon's Annotated Missouri Statutes, 1960, Sec. 167.090 .
} 
TABLE I

\section{STATUTORY PROVISIONS GOVBRIVING THE PRESCRIPTION \\ OF SCHOOL DISTRICT FINANCIAL ACCOUNTING PORLS}

\begin{tabular}{|c|c|c|}
\hline State & Agency prescribing forms & $\begin{array}{l}\text { Use } \\
\text { Optional, } \\
\text { directory, } \\
\text { or } \\
\text { mandatory }\end{array}$ \\
\hline $\begin{array}{l}\text { Alabama } \\
\text { Alaska }\end{array}$ & $\begin{array}{l}\text { State Board of Education } \\
\text { State Department of Adminis- } \\
\text { tration }\end{array}$ & $\begin{array}{l}\text { Vandat ory } \\
\text { vandat ory }\end{array}$ \\
\hline $\begin{array}{l}\text { Arizona } \\
\text { Arkansas } \\
\text { California }\end{array}$ & $\begin{array}{l}\text { State Sxarniner } \\
\text { State Board of Iducation } \\
\text { State Superintendent }\end{array}$ & $\begin{array}{l}\text { Diandatory } \\
\text { Directory } \\
\text { Directory }\end{array}$ \\
\hline $\begin{array}{l}\text { Colorado } \\
\text { Connecticut } \\
\text { Delaware } \\
\text { Florida } \\
\text { Georgia }\end{array}$ & $\begin{array}{l}\text { State Board of Education } \\
\text { State Tax Commissioner } \\
\text { State Board of Dducation } \\
\text { State Board of iducation } \\
\text { State Board of Education }\end{array}$ & $\begin{array}{l}\text { Directory } \\
\text { Optional } \\
\text { Directory } \\
\text { Directory } \\
\text { Directory }\end{array}$ \\
\hline $\begin{array}{l}\text { Hawaii } \\
\text { Idaho } \\
\text { Illinois } \\
\text { Indiana } \\
\text { Iowa }\end{array}$ & $\begin{array}{l}\text { State Comptroller } \\
\text { State Board of iducation } \\
\text { State Superintendent } \\
\text { State Board of Accounts } \\
\text { State Superintendent }\end{array}$ & $\begin{array}{l}\text { Diandatory } \\
\text { Directory } \\
\text { Mandatory } \\
\text { viandatory } \\
\text { Mandatory }\end{array}$ \\
\hline $\begin{array}{l}\text { Kansas } \\
\text { ienticky } \\
\text { Louisiana } \\
\text { iaine } \\
\text { iaryland }\end{array}$ & $\begin{array}{l}\text { State Superintendent } \\
\text { State Superintendent } \\
\text { State Supervisor of Accounts } \\
\text { State Departinent of Audits } \\
\text { State Board of Hucation }\end{array}$ & $\begin{array}{l}\text { Wandatory } \\
\text { Wanciatory } \\
\text { Wandatory } \\
\text { Wandatory } \\
\text { Wandatory }\end{array}$ \\
\hline $\begin{array}{l}\text { Massachusetts } \\
\text { Michigan } \\
\text { Minnesota } \\
\text { Mississippi } \\
\text { Missouri }\end{array}$ & $\begin{array}{l}\text { State Director of Accounts } \\
\text { State Superintencient } \\
\text { State Soard of Sducation } \\
\text { State Auditor } \\
\text { State Board of iducation }\end{array}$ & $\begin{array}{l}\text { Optional } \\
\text { Mandatory } \\
\text { Directory } \\
\text { Wandatory } \\
\text { Directory }\end{array}$ \\
\hline $\begin{array}{l}\text { Montana } \\
\text { Nebrasia } \\
\text { Nevada } \\
\text { New Hampshire } \\
\text { New Jersey }\end{array}$ & $\begin{array}{l}\text { State Superintencient } \\
\text { State superintendent } \\
\text { State nssistant Superintendent } \\
\text { State Tax Commissioner } \\
\text { State Soard of iducation }\end{array}$ & $\begin{array}{l}\text { Directory } \\
\text { iviandatory } \\
\text { ivandat ory } \\
\text { iviandat ory } \\
\text { Nianciat ory }\end{array}$ \\
\hline
\end{tabular}


TABLE I (cont.)

\begin{tabular}{|c|c|c|}
\hline State & Agency prescribing forms & $\begin{array}{l}\text { Use: } \\
\text { Optional, } \\
\text { directory, } \\
\text { or } \\
\text { mandatory }\end{array}$ \\
\hline $\begin{array}{l}\text { New Mexico } \\
\text { New York } \\
\text { North Carolina } \\
\text { North Dakota } \\
\text { Ohio }\end{array}$ & $\begin{array}{l}\text { State School Finance Division } \\
\text { State Commissioner } \\
\text { State Board of iducation } \\
\text { State Examiner } \\
\text { State superintendent }\end{array}$ & $\begin{array}{l}\text { Mandatory } \\
\text { Directory } \\
\text { Directory } \\
\text { Mandatory } \\
\text { Mandatory }\end{array}$ \\
\hline $\begin{array}{l}\text { Oklahoma } \\
\text { Oregon } \\
\text { Pennsylvania } \\
\text { Rhode Island } \\
\text { South Carolina }\end{array}$ & $\begin{array}{l}\text { State Examiner } \\
\text { State Superintencient } \\
\text { State Department of Lducation } \\
\text { State Board of Education } \\
\text { State Comptroller General }\end{array}$ & $\begin{array}{l}\text { Mandatory } \\
\text { Directory } \\
\text { Directory } \\
\text { Mandatory } \\
\text { Iviandatory }\end{array}$ \\
\hline $\begin{array}{l}\text { South Dakota } \\
\text { Tennessee } \\
\text { Texas } \\
\text { Utah } \\
\text { Vermont }\end{array}$ & $\begin{array}{l}\text { State Superintendent } \\
\text { State Comptroller } \\
\text { State Commissioner } \\
\text { State Finance Commission } \\
\text { State Board of Lducation }\end{array}$ & $\begin{array}{l}\text { Directory } \\
\text { Uptional } \\
\text { Diandatory } \\
\text { Directory } \\
\text { Optional }\end{array}$ \\
\hline $\begin{array}{l}\text { Virginia } \\
\text { Washington } \\
\text { West Virginia } \\
\text { Wisconsin } \\
\text { Wyoming }\end{array}$ & $\begin{array}{l}\text { State Board of Education } \\
\text { State Auditor } \\
\text { State Board of Finance } \\
\text { State Auditor } \\
\text { State Examiner }\end{array}$ & $\begin{array}{l}\text { Mandatory } \\
\text { Mandatory } \\
\text { Mandatory } \\
\text { Optional } \\
\text { Mandatory }\end{array}$ \\
\hline
\end{tabular}


the installation of a system prescribed by the State Director of Accounts in the former and the State Board of Education in the latter. The system prescribed by the State Auditor is installed in Wisconsin at the request of the local board of education. The statutory provisions in Tennessee anci Connecticut allow the local districts to use their own systens of accounting, providing these meet with the approval of a state agency. In Tennessee the system must be approved by the Governor and the State Comptroller, while in Connecticut the system must meet the approval of the State Tax Commissioner.

Compliance with statutory provisions has been listed as mandatory on the local school district when the statute under consideration employs such terms as "compel," "require," "enforce," and "shall" or the forms appear in the statutes. Statutory provisions which simply give the ajency responsible for the prescription of accounting forms and leave the compliance with the provisions in doubt have been listed as directory. Twenty-nine of the 50 states have statutory pro-: visions which the writer has interpreted as being mandatory, and sixteen have provisions the writer classified as directory.

Table II presents the same data as Table I in summary form. Several factors have become apparent from examining existing statutes. Thirty of the states have placed the prescription of a uniform system of accounting with the 
TABLE II

SUMIMARY OF STATUTORY PROVTSTONS FOR UNIFORI SCHOOL DISTRICT FINANCIAL ACCOUNTING SYSTEMS

No. of

states

Having provisions for a prescribed uniform system of accounting

50

Use of the system is optional

5

State Board of iducation prescribes forms

14

Chief state school officer or department prescribes forms

16

State Department of Finance or Accounts prescribes forms

6

State Auditor prescribes forms

4

State Comptroller prescribes forms

3

State Examiner prescribes forns

4

State Tax Coumission prescribes forms

2

Other agencies prescribe forms

$1^{\mathbf{a}}$

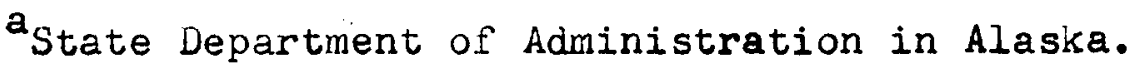


state educational authorities (state board of education or the chief state school officer and his department). Six of the states have placed this responsibility in the hands of the state department of finance and accounts: Indiana, Louisiana, Viassachusetts, ivew ilexico, Utah, anci West Virginia. The state auditor has this responsibility in the four states of Waine, ivississippi, Washineton, and Nisconsin. The state examiner also prescribes forms in four states: Arizona, North Dakota, Oklahoma, and Wyoming. Connecticut and New Hampsire statutes place this responsibility with the state tax commissioner.

The State Department of Administration in Alaska prescribes a uniform accounting system for all municipal corporations, including school districts.

Twenty of the states have placed the responsibility for the prescription of uniform accounting systems for school districts with non-educational state agencies. This indicates the extent of control by non-educational agencies over the prescription of forms used by school districts. In the enforcement of using prescribed accounting forms, the states vary in degree to compelling the use of the prescribed system or to having the system optional on the part of the school district.

\section{BUDGETARY FORMS AND PROCEDURES}

In view of the fact that in most of the states the 
construction of the school district budget is a legal function and the budget directly controls the educational opportunities of the pupils at the local level, it is important to examine the statutory provisions imposed by the various state legislatures upon the construction of the local school budget.

The public has shown a growing concern over increased school expenditures within recent years. The New York Times recently devoted several columns to the defeat of school district bucigets by the people in the state of New Jersey. 5 Therefore, this section of the study is devoted to answering the following questions in regard to the preparation, adoption, and use of school cistrict budgets:

1. What states require the construction of school district estimates anci budgets?

2. What agency has the major responsibility in the construction of the local buciget?

3. What other agency at the local level, if any, must also approve the budget or estimate?

4. What agency at the state level, if any, must also approve the budget or estimate?

The budget, as it applies to this study, is defined

in the terms proposed by Reason and white:

Budget- A plan of financial operation embodying an estimate of proposed expenditures for a given period or purpose and the proposed means of financing them. The budget usually consists of three parts. The first

\section{The New York Times, February 15, 1962, Part C,}


part contains a message from the budget making authority together with a summary of the proposed expenditures and the means of financing them. The second part consists of schedules supporting the summary. These schedules show in detail the proposed expenditures and means of financing them together with information as to past year's actual revenues and expenditures and other data used in making the estimates. The third part is composed of drafts of the appropriation, revenue, and borrowing measures necessary to put the budget into effect. 6

The budget may be defined also as an administrative control, according to ingelhardt: "The budget, as it is f1nally adopted, becomes the controlling instrument of a year's educational prograrn. The preliminary discussions have resulted in broad uncierstanding throughout the rank and file, of the work to be undertaken and the methocis to be employed." 7

Fowlkes combined the technical and non-technical definition of the school budget when he wrote:

From a technical standpoint, a school budget may be defined as a financial plan of a school's program for a given period of time --usually one year-- indicating amounts and sources of anticipated revenues and amounts and purposes of proposed expenditures. A non-technical definition of the school budget is the fiscal interpretation or reflection of the school's policies and activities. This non-technical definition of a school budget should be the governing concept of all budgetary

${ }^{6}$ Paul L. Reason and Alpheus L. White, Financial ÂCcounting for Local and State School Systems, U.S. Uffice of Education TWashington, D.C.: Government Printing Office, 1960), p. 218 .

7.L. Engelhardt, "The School Budget as an Administrative Control," The School Executive, LXVII (November, 1947), 44 . 
activities for a school. 8

In Budgeting for Better Schools, a textbook by Ovsiew and Castetter on the construction and administration of the school budget, the authors summarize the control of budgetary expenditures by stating:

There is no clear cut pattern of expenditure control of public school funds. The controls are many and varied, direct and indirect, subtle and blunt. Expenditure controls in some states are in effect controls on revenue which can be raised. In other states there are controls over the percentage of the current budget which may be spent for each budget category ....

Expenditure controls are also exercised tirough debt limits, salary schedules, budgetary review by state and local authorities, bidding requirements, audits, accounts, financial reports, and rules and regulations of state administrative agencies.

Experience has shown that many types of expenditure controls, like revenue controls, unduly hamper school officials who are interested in developing adequate educational programs. Some controls are necessary, to be sure. But surely many of the controls now in existence are no longer functional ano serve no gainful purpose; their effect is to hamper educational progress. Niany are inconsistent with the principle of local initiative.9

The authors' summary of the practices in the administration of the school budret includes:

In 23 states, local boards have complete authority to prepare and adopt school budgets without submission to a non-school agency.

8 John Guy Fowlkes, "School Policies and the Budget," The School Executive, LXVII (Novemoer, 1947), 45.

9 Leon Ovsiew and William B. Castetter, Budgeting for Better Schools (Englewood Cliffs: Prentice-Hall, Inc., 1960), p. 95 . 
For the remaining states, the review may not be required of all kinds of school districts.

In 35 states the local school district budget must be filed with a state agency.

In 13 states tine local school district budget must be filed with a state non-school agency.

The extent of authority of the state agency with respect to the proposed budget varies from no authority to the right to change any item in the budget. 10

The extent of the authority of the various state agencies is of concern to this section of the study. The issue is not only with the mere filing of the budget, but also with the authority of the state agency to alter and change the items of the local budget when subinitted for approval. This study is also concerned with the interpretation of the courts when budgetary approval and procedure have resulted in litigation.

The materials presented in Tuble III deal with a number of the questions proposed at the beginning of this discussion. The table describes the controls exercised by both local and state agencies over local school district budgets. Entries were made in the table if the control under question is exercised on all or on part of the school districts within the state under consideration. Only those agencies within a state that must give written or oral approval, or those that have the responsibility to see that

$$
{ }^{10} \text { Ibid. , pp. 83-87. }
$$




\section{TABLE III}

STATUTORY PROVISIONS GOVERNING THE APPROVAL OF LOCAL SCHOOL DISTRICT BUDGETS

\begin{tabular}{|c|c|c|c|}
\hline State & Agency making budget & County or local approval & State approval \\
\hline $\begin{array}{l}\text { Alabama } \\
\text { Alaska }\end{array}$ & $\begin{array}{l}\text { District board } \\
\text { District board }\end{array}$ & $\begin{array}{l}\text { None } \\
\text { City Council }\end{array}$ & $\begin{array}{l}\text { State Superincendent } \\
\text { Commissioner of } \mathrm{du}- \\
\text { cation }\end{array}$ \\
\hline Arizona & District board & Board of Supervisors ${ }^{2}$ & None \\
\hline Arkansas & District Board & None & $\begin{array}{l}\text { State Dept. of Educa- } \\
\text { tion }\end{array}$ \\
\hline California & District Board & None & None \\
\hline $\begin{array}{l}\text { Colorado } \\
\text { Connecticut } \\
\text { Delaware } \\
\text { Florida } \\
\text { Georgia }\end{array}$ & $\begin{array}{l}\text { District Board } \\
\text { District Board } \\
\text { District Board } \\
\text { District Board } \\
\text { District Board }\end{array}$ & $\begin{array}{l}\text { None } \\
\text { Board of Finance } \\
\text { None } \\
\text { None } \\
\text { City Councilc }\end{array}$ & $\begin{array}{l}\text { State Tax Commission } \\
\text { None } \\
\text { State Buaget Commission } \\
\text { State Superintendent } \\
\text { State Boara of Educa- } \\
\text { tion }\end{array}$ \\
\hline $\begin{array}{l}\text { Hawaii } \\
\text { Idaho } \\
\text { Illinois } \\
\text { Indiana } \\
\text { Iowa }\end{array}$ & $\begin{array}{l}\text { State Budget Dept. } \\
\text { District Board } \\
\text { District Board } \\
\text { District Board } \\
\text { District Board }\end{array}$ & $\begin{array}{l}\text { Board of Supervisors } \\
\text { None } \\
\text { None } \\
\text { County Tax Board } \\
\text { None }\end{array}$ & $\begin{array}{l}\text { State Budget Dept. } \\
\text { None } \\
\text { None } \\
\text { State Tax Commission } \\
\text { None }\end{array}$ \\
\hline
\end{tabular}

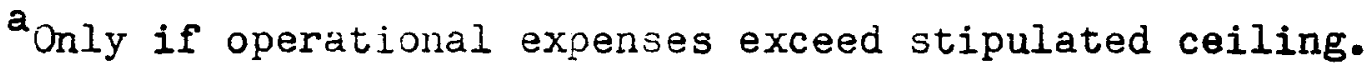

$b_{\text {Only }}$ if expenses exceed stipulated ceiling.

conly in fiscally dependent districts. 


\section{TABLE III (cont.)}

State Agency making budget County or local approval

State approval

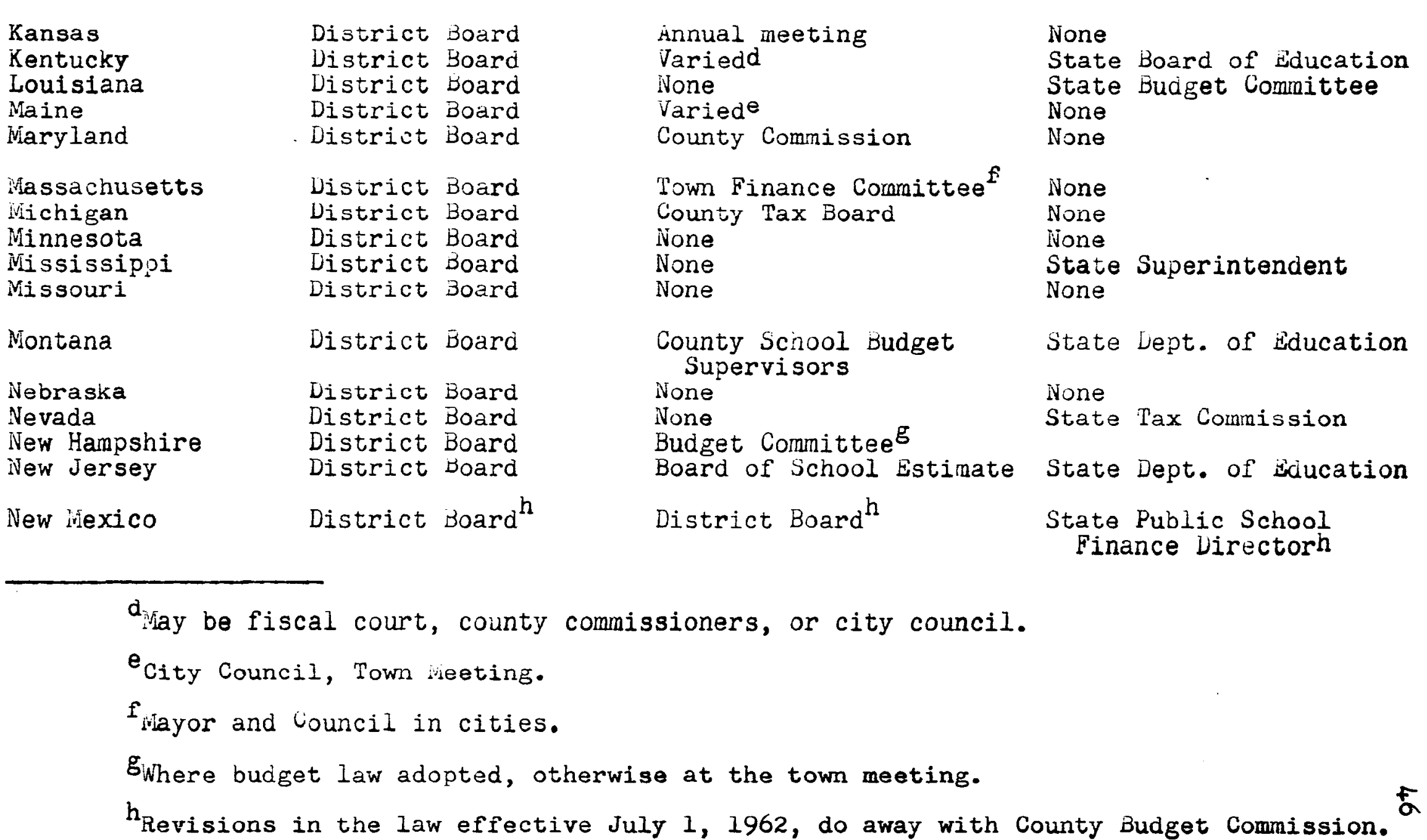


TABLE III (cont.)

\begin{tabular}{|c|c|c|c|c|}
\hline $\begin{array}{l}\text { New York } \\
\text { North Carolina } \\
\text { North Dakota } \\
\text { Ohio } \\
\text { Oklahoma }\end{array}$ & $\begin{array}{l}\text { District Board } \\
\text { District Board } \\
\text { District Board } \\
\text { District Board } \\
\text { District Board }\end{array}$ & $\begin{array}{l}\text { City Council } \\
\text { County Board of Supervisors } \\
\text { Board of Budget Review } \\
\text { County Budget Commission } \\
\text { County Bxcise Board }\end{array}$ & $\begin{array}{l}\text { None } \\
\text { None } \\
\text { None } \\
\text { State } \\
\text { None }\end{array}$ & Board of Education \\
\hline $\begin{array}{l}\text { Oregon } \\
\text { Pennsylvania } \\
\text { Rhode Island } \\
\text { South Carolina } \\
\text { South Dakota }\end{array}$ & $\begin{array}{l}\text { District Board } \\
\text { District Board } \\
\text { District Board } \\
\text { District Board } \\
\text { District Board }\end{array}$ & $\begin{array}{l}\text { County Tax Board } \\
\text { None } \\
\text { Town Weeting } \\
\text { Nonek } \\
\text { County Auditor }\end{array}$ & $\begin{array}{l}\text { State } \\
\text { None } \\
\text { State } \\
\text { None } \\
\text { None }\end{array}$ & $\begin{array}{l}\text { Tax Coinmission } \\
\text { Lept. of diucation }\end{array}$ \\
\hline $\begin{array}{l}\text { Tennessee } \\
\text { Texas } \\
\text { Utah } \\
\text { Vermont } \\
\text { Virginia }\end{array}$ & $\begin{array}{l}\text { District Board } \\
\text { District Board } \\
\text { District Board } \\
\text { District Board } \\
\text { District Board }\end{array}$ & $\begin{array}{l}\text { Quarterly Court } \\
\text { None } \\
\text { None } \\
\text { Town iveting } \\
\text { County Supervisors }\end{array}$ & $\begin{array}{l}\text { None } \\
\text { State } \\
\text { None } \\
\text { None } \\
\text { None }\end{array}$ & Dept. of Education \\
\hline $\begin{array}{l}\text { Washington } \\
\text { West Virginia } \\
\text { Wisconsin } \\
\text { Wyoming }\end{array}$ & $\begin{array}{l}\text { District Board } \\
\text { District Board } \\
\text { District Board } \\
\text { District Board }\end{array}$ & $\begin{array}{l}\text { County Review Committee } \\
\text { None } \\
\text { City Council } \\
\text { None }\end{array}$ & $\begin{array}{l}\text { None } \\
\text { State } \\
\text { None } \\
\text { State }\end{array}$ & $\begin{array}{l}\text { Board of Finance } \\
\text { Examiner }\end{array}$ \\
\hline
\end{tabular}

${ }^{i}$ In certain size cities only.

$j_{\text {State }}$ Tax Commission deternines legality on appeal.

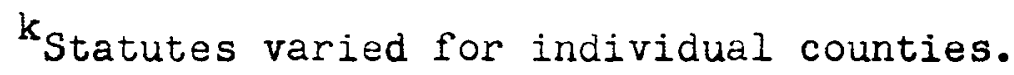

$1_{\text {City }}$ Council in certain cities.

${ }^{m}$ In certain cities only.

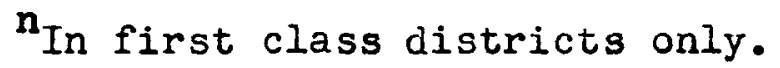


the budgets conform to legal requirements have been included. Within many of the states, statutes are written to the exclusion of certain class or size school districts. As a result of this, buiget approval ray be the responsibility of several agencies. For example, in Georgia the State Constitution, section VII, allows the continuation of municipal school systems which are depencient upon the city council for support of schools. However, most of the schools are under the county-wide system with a county board of education as the governing board. Table III has reported these exceptions by footnotes.

The state of liew York provides another example of the confusion that is found in regard to approval of school district budgets. The various classes of school districts in New York are as follows:

1. Common school districts

2. Union free school districts

3. Central school districts

4. Central high school districts

5. Intermediate school districts

6. Supervisory districts

7. City school districts of cities with less than 125,000 inhabitants

8. City school districts of cities with 125,000 inhabitants or more. 11

\footnotetext{
${ }^{11_{\text {New }}}$ York State Education Law (Albany, New York: 1957), p. $\overline{191 .}$
} 
In common, union free, central, central high school, interinediate, and supervisory school districts, budgets are approved at the annual meeting. In the city school districts they are approved by the mayor and council after following the same procedures prescribed for all other municipal departments.

Several states --namely, Kansas, Niaine, New Hampshire, New York, Rhode Island, and Vernont-- have provisions to have school budgets approved at the annual town meeting or by another agency, depending on the particular district under consideration.

In New Jersey the local budget must be approved by the Board of School Estimate and then be voted on by the people. Effective July 1,1962 , New Nexico school districts will approve their own budgets under a new statute which abolishes the County Budget Comrnittee. ${ }^{12}$ Local budgets will be reviewed by the State Director of the Public school Finance Division. Budgets are reviewed by a local conmittee in New Hampshire where the Wunicipal Budget Law has been adopted.

The method of budget approval in the state of Hawaii is worthy of special comment. Currently there are no local school districts in Hawaii. The budget is prepared for the

12 House Appropriations and Finance Committee Substitute for House Bill No. 15, Special Session, 1962, Twenty-fifth Legislature, state of New Mexico. 
individual counties by the State Budget Department and submitted to the county board of supervisors to be included in their over-all county levy.

In the states of Arizona and Colorado, agencies must pass on proposed expenditures only if they exceed a stipulated ceiling. In Arizona the county board of supervisors rules on proposed expenditures if the ensuing year's operational expenses exceed 6 per cent of the ainount arrived at by the statutory provisions for computation. A similar function is exercised by the State Tax Commission in Colorado. The State Tax Cormission in Indiana has the power to reduce the levy of a proposed budget if it exceeds a stipulated ceiling. The State Tax Commission in Oregon determines the legality of the budget only on appeal.

In the state of Kentucky, city districts have their budgets approved by the mayor and council; county districts by the Quarterly Court.

It can be seen from these examples that approval of school district budgets does not follow any one set pattern either among the states themselves or within the districts of the individual states.

Table IV contains the same information as Table III in summary forin. All states require some form of a budget to be constructed. Forty-nine states allow the budget to be constructed by the governing board of the school district. The one state not following this pattern is Hawail, discussed 
TABLE IV

SUMMARY OF STATUTORY PROVISIONS GOVERNING THE APPROVAL OF LOCAL SCHOOL DISTRICT BUDGETSA

No. of

states

Some form of budget is required

District board is responsible for making budget

49

Budget is made by an agency other than the district board

All or part of the districts require county or local agency approval

Chief state school officer or his department is required to approve budgets

State Board of Education is required to approve budgets

No state agency approval is required

State Tax Commission approves budgets 5

State Budget or Finance Department approves budgets 5

Other state agencies must approve budgets I

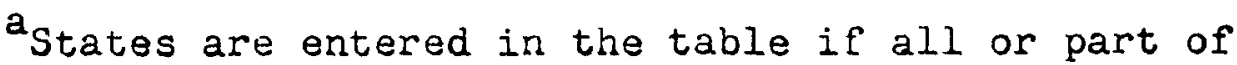
the districts within the state are subject to approval by the agency mentioned. 
earlier in this section.

Twenty-seven of the states require the budget to be approved by a local non-educational agency. INost frequently this agency is the county board of supervisors, the county tax board, or the mayor and council. This indicates that local non-educational agency approval of proposed school expenditures is relatively common.

Twenty-three states require the budgets of the local districts to be approved by a state agency. In 12 of the 23 states requiring state agency approval, it is the responsibility of the state educational authorities. The other 11 states have the budget approved by non-educational agencies. The most common state agencies having this responsibility in the 11 states are the state tax commission and the state department of budget and finance.

How have the courts ruled where conflict between state and local agencies has resulted in litigation? Decisions of the courts will now be presented. In this question also, the rulings of the courts depend on what is held to be the intent of the legislature in cirafting statutes, and whether the statutory provisions for a given state are determined as mandatory, directory, or optional.

Some of the major issues that have been decided by the courts in regard to conflicts over school district budgets that are of importance to this study include such items as: 
1. The degree of itemization that a budget must be presented in before it meets statutory provisions

2. The amount of funds the can be transferred between items in budget category and between categories

3. The power of state and local agencies to reduce the budget as a whole, as well as individual items in the budget

4. The purchase of equiment that must meet state agency approval

5. The granting of increases or reductions in school employees' salaries.

The degree of itemization or particularity of a school budget when proposed for adoption has been the question of several court decisions. In Utah, the validity of the budget of the Board of Education of salt Lake City ${ }^{13}$ was attacked by a group of taxpayers of that city on the grouncis that the budget had not been itenized according to statute. The prepared and adopted budget by the Board of Education consisted of ten major classifications, which read as follows:

$\begin{array}{lr}\text { Administration } & \$ 65,200.00 \\ \text { Instruction } & 1,961,500.00 \\ \text { Operation of Buildings } & 217,500.00 \\ \text { Maintenance of Buildings } & 113,000.00 \\ \text { Auxiliary Agencies } & 38,000.00 \\ \text { Fixed Charges } & 36,500.00 \\ \text { Building Fund } & 120,000.00 \\ \text { Sinking Fund } & 87,900.00 \\ \text { Interest Fund } & 171,000.00 \\ \text { Reserve } & 40,000.00\end{array}$

The section of the Utah statutes under consideration by the Supreme Court of Utah was that dealing with "School District

13 Tuttle et al. v. Board of Education of Salt Lake City et al., 77 U. 270, 294 P. 294 (1930). 
Budget," Chapter 75, Laws of Utah 1927, p. 128. It stated, "The classification of titles and accounts in such budget shall be equivalent to the district's classifications of titles and accounts for the current year."14 The superintencient's buaget as adopted by the Board consisted of 60 sub-items uncier the ten gener I catefories. The school district produced school records to show that the 60 sub-items proposed by the superintendent were broken down further into 1,500 sub-items by the administration for accounting purposes. In discussing the use of the term "accounts" in the above statute, the Court ruled:

In the use of the term "accounts, "it is rither hard to believe the legislature meant anything more than a mere statement or surnnary, and not a detailed financial statement of items of receipts and expenditures, or petty details of administration.15

The significant feature of this case is that the Court interpreted the intent of the legislature when drafting the statute and using the woras "classifications," "titles," and "accounts." The Court's interpretation of these words was:

Word "classification" as used in school budget statute, means putting together of like subjects or facts under common designation.

Word "title" as used in school budget statute means descriptive caption or heading.

Word "accounts" as used in school budget statute means mere general statement, and not a detailed

${ }^{14}$ Ibid. ${ }^{15}$ Ibid. 
financial statement of items of receipts and expenditures.

School board, adopting buciget by taking only general headings as prepared by superintendent's tentative budget, could not be compelled to adopt buclget by taking, not only general heading, but also subdivisions together with amount of money to be appropriated for each subdivision as prepared by superintendent's tentative budget. 16

A question as to the necessary detail of the school budget arose in the state of laryland, 17 where the budget is reviewed by the county commissioners before making the necessary levy. The agency has the power, by statute, to reduce or refuse to levy for specific items. The commissioners, however, must submit their refusal in writing and the reason for their refusal. This was not done in the instant case. The item under consideration was listed as "Incidentals" (including janitor's salaries of $\$ 7,500.00$ ). The court said:

These items certainly cannot be said to contain a detailed statement of the particulars that go to make up the total amounts of the items, and we concur in the conclusion of the learned court below that the buciget furnished by the petitioners was not in comoliance with the terms of the law.

But in our view that is not the controlling feature of this case. The county cormissioners did not require further details of any iteins set out in the budget excepcing that relating to salaries, but acted upon the budget, as nodified by further details in regard to salaries .... Having declined to approve and sanction the amount asked for by the Board of Education, it becane incumbent upon the board of county conmissioners,

${ }^{16}$ Ibid.

17 Board of Education of Prince George's County v. County Com'rs., 131 Md. 658, 102 A. 1007 (1917). 
under the expressed terms of the statute, to indicate in writing what items of the budget were denied in whole or in part and their reasons for such denial, and such statement on the part of the county commissioners is made necessary for the reason that the board of education is required by statute to expend all taxes received py it in accordance with the items of their budget. 18

The ruling in the above case was against the county commissioners for refusing to give in writing their reason for denial, even though the budget was not in "detail" as required by statute. It appears that in budgetary practice, items listed as "Incicientals" or "Miscellaneous" should be sufficiently itenized to conform to statutory provisions, or they shoulu be omitted.

The transfer of funds from one item of a budget to another was recently interpreted by the courts of Arizona. 19 The statute under question states:

No expenditure shall be made for a purpose not particularly iterized and included in such budget, and no expenditure shall be made, and no debt, obligation or liability shall be incurred or created in any year for any purpose itemized in such budget in excess of the amount specified for such sum ....20

The Arizona budget forn is printed in its entirety in the statutes. The Legislature when making the buaget did not include lines across the 41 sub-items under the "Operating expense" division. Lines were provided, however, for the totals of the six sub-sections, as well as the individual

${ }^{18}$ Ibid. ${ }^{20}$ Ibid. ${ }^{19}$ Phil A. Insley and W.W. Dick v. School District No. 2, 81 Ariz. 280, 305 P. 2nd 432 (1956). 
items of the "Capital Outlay" division. The question raised was whether sums of money can be transferred among the 41 sub-items within the six major divisions of the budget. The court held:

While this in itself strongly indicates that the legislature intended a six-line rather than a forty-one line operating budget to control, the facts reflect still other circumstances which make this conclusion tenable and reasonable.

It is the rule of statutory construction that where the language of the statute is susceptible to two interpretations the court will adopt the one which is reasonable.

It appears to us that to bind either the school district or the superintendent to a forty-one-line operating expense budget, as advocated by the appellant, would be impracticable, unduly restrictive, and lead to absurd results. We, therefore, hold that the word "purpose" as used in the above sections, has reference, as far as the "Operating Expense"l division of the budget is concerned, to the six general categories rather than the forty-one subitems contained therein.2I

In the case of People ex rel. Schlager v. Reilly Tar and Chemical Corporation, 22 the question of non-itemization of funds and the illegal charging of items to certain categories was answered by the Illinois Supreme Court:

The Board of Education has levied its maximum rate for educational purposes and, notwithstanding this fact, attempts to charge to other funds expenses which are, without question, educational purposes, the result being not only that the appropriations are illegally charged to the wrong funds but that the error, if corrected by charging the appropriations to the

\section{$21_{\text {Ibid. }}$}

22 People ex rel. Schlager v. Reilly Tar and Chemical Corporation, 389 Ill. 434, 59 N.E. 2nd 843 (1945). 
educational fund, would increase the levy for the educational fund beyond the maximum of $\$ 52,000,000.00$ permitted by law. 23

According to the above case, expenses must be charged to the proper category. If an expenditure belongs in the educational fund, transportation fund, etc., it aust be charged against that fund and cannot be placed as a charge against another section of the budget.

In the state of Virginia the proposed budget must pass the approval of the county board of supervisors who, by statute, have the right to reduce the proposed budget. In the case of Scott County School Board v. Scott County Board of Supervisors, ${ }^{24}$ the Virginia Supreine Court ruled:

We think the board of supervisors had the right and it is their duty to scan the items of expense of the school system .... The financial ability of a county is better known to the Board of Supervisors than to anyone else, and it is their duty to determine whether or not the estimates submitted for school purposes are in line with the "financial ability" of the county. 25

The reasoning here is that the supervisors have a better grasp of the financial condition of the county to support schools and have the right to determine the amount to be spent for school purposes.

${ }^{23}$ Ibid.

${ }^{24}$ Scott County School Board v. Scott County Board of Supervisors, $169 \mathrm{Va} .213,193$ S.E. 52 (1937).

25 Ibid. 


\section{A similar question arose in Virginia a few years}

later. This time the board of supervisors refused to honor requests to pay additional salary compensation to a superintendent who had received a salary increase by the board of education. 26 The board of supervisors pleaded that it was their duty and right to scan the budget and cut the items according to their estimate of the financial ability of the county. The Supreine Court ruled that the county board of supervisors is concerned only with:

... the total amount of the tax to be levied, and not individual items of the school budget .... After the board of supervisors have appropriated money for schools, the exclusive right to determine how this money shall be spent is in the discretion of the school board, so long as they stay within the limits set up in the budget.27

Several cases arose in the state of Hassachusetts 28 in which the schoul committees when subuitting estimates to the mayor anc council provided for an increase in teachers' salaries. The mayor and council refused to make the necessary appropriations for salary increases. In each case

26 Board of Sup'rs. of Chesterfield County et al. v. County School Board of Chesterfield County, 182 Va. 266, 28 S.E. 2nd 698 (1944).

27 Ibid.

28 Leonard et al. v. School Committee of Springfield et al., 241 lvass. 325, 135 N.E. 459 (1922); Ring et al. v. City of Woburn, 311 Mass. 679,43 N.E. 2nd 8 (1942); Hayes et al. v. City of Brockton, 313 Mass. 64, 48 N.E. 2nd 683 (1943). 
the Supreme Judicial Court ruled that setting salaries and the method of spending money in the budget should be left to the discretion of the school comittee which is empowered by law to operate the public schools.

Under other statutes the power of a school board to reduce a teacher's salary for the coming year was upheld in several Penusylvania cases where teachers sought mandamus proceedings to have the saine salary paid for the ensuing year as was paid during the current year. 29 These cases indicate the power of the school board in expending funds as they see fit.

Even if the school committees of the school districts of ivassachusetts do not file the estinated school budget according to the time scheduled in the statutes, cities are expected to honor their requests and appropriate tine necessary funds for the operation of the schools. So ruled the Suprene Judicial Court in Dorothy Whipole Illig et al. v. Town of Plymouth. 30

If equipment is to be purchased from the school budget and state approval of the items is required, the contractor operates at his peril and is expected to know the powers and

${ }^{29}$ Smith v. School District of Philadelphia et al., $334 \mathrm{~Pa} .197,5 \mathrm{~A}$. 2nd 535 (1939); Sylvia Drasin v. School District of Philadelphia, $334 \mathrm{~Pa}$. 210, 5 A. 2nd 549 (1939); Marcovitz v. School District of Philadelphia et al., $5 \mathrm{~A}$. 2nd 540 (1939).

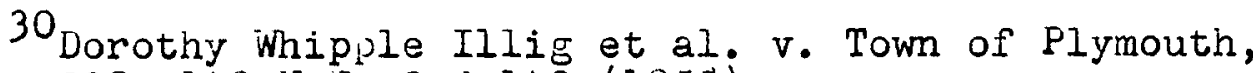
337 ivass. 239, $149 \mathrm{~N} . \mathrm{E}$. 2nd 140 (1958). 
duties of the school board. So ruled the court in the case of the First National Bank of Waldron v. Whisenhunt et al., 31 where the school board did not secure the state superintendent's approval of certain maps and charts to insure that the price and merit of the naterial were suitable.

\section{AUDIT FORIS AND PROCEDUURES}

For purposes of this section, the audit is defined

as:

The examination of records and documents and the securing of other evidences for one or more of the following reasons: (a) determining the propriety of proposed or completed transactions, (b) ascertaining whether all transactions have been duly recorded, (c) determining whether transactions are accurately recorded in the accounts and in the statements dram from the accounts. 32

From this definition, it appears that school district audits are conducted for the following purjoses:

1. To determine the honesty of the individuals transacting school district business

2. To deternine whether business transactions were conducted accurately

3. To deterinine whether expenditures made by school officials were properly recorded and within the legal limits of the prevailing state statutes.

Rosenstengel listed similar reasons for conducting a financial audit in the Nay, 1941, issue of The American

${ }^{31}$ First ivational Bank of Waldron v. Whisenhunt et a1., 94 Ark. 58, 127 S.W. 968 (1910).

32 Reason and White, og. cit., p. 217. 
School Board Journal:

The financial records of a school system should be audited annually and the audit filed as a part of the perinanent recoras of the school district.

Reasons for auditing:

To give assurance of the correctness of the financial statenents.

To prevent fraud.

To detect fraud.

To check on the consistency of record keeping.

To protect the cinief administrator.

To make the general public feel that honest management is being given to the schools.

To give unbiased information for public relations.

To secure professional services for improving accounting systems.33

In ciscussing auditing controls, Horphet lists the following as being undesirable for the efficient operation of a school:

Among these are the deternination of the services for which funds may be expended; the question of whether money has been most wisely and economically spent; the proportion of funds that should be expended for any service or group of services, and the services for which expenditures are to be budgeted. 34

33 W. E. Rosenstengel, "The Annual Financial Audit," The American jchool Board Journal, CII (Nay, 1941), 42.

34 Edgar L. wiorphet, "Auditing Services; Where the Line Should Be Drawn," The Nation's jchools, XixII (July, 1938), 34 . 
Flint, 35 writing at the University of Missouri, made some suggestions for the implementation of the public school audit law for the state of liissouri. The purvose of his study was to secure and present auditing data which would serve as a guide and source of information for ivissouri public school of icicials. he examined the current literature to locate the desirable principles for an auditing system, and then discussed the data collected from 35 classified AAA school districts gathered by means of a questionnaire. His nine sumnary points are:

The purpose for which audits of public school funds are made should be much broader than merely that of safeguarding funds.

The authority and responsibility in connection with the audit should be definitely established and penalties for nonperformance should be adopted.

From the point of view of audit frequency, the annual audit is preferred. audit.

The audit should be an independent, external post

The auditor should be competent and properly qualified.

The audit should not be in conflict with ecucational policy.

Certain definite understandings between tine auditor and the client are necessary to insure the success of the audit, and such understandings are best provided for through the use of a written contract.

35 Jack Wetzler Flint, "Some Suggestions for the Implementation of the irissouri Public School Audit Law" (unpublished Doctor of Education dissertation, University of Missouri, Columbia, 1957); Dissertation Abstracts, XVII (August-October, 1957), 2191. 
Although the audit should involve certain basic data and procedures, and should embrace all requirements under standards for such an audit examination as established by law or the resuonsible state auditing agency, there should be no fixed pattern of auditing procedures.

A written report should be made for each audit performed. Copies of this report should be filed with the responsible parties concerned, and the contents made available to the public.36

The aterials presented in this section relate to the effect of existing statutes on the purposes stated earlier. Statutes were examined to answer the following questions :

1. Which of the states require an audit to be made?

2. What is the frequency of the required audit?

3. What person or agency has the resionsibility for the conduct of the audit?

4. Are audits required of all districts within a given state? Court decisions were examined where questions regarding the general school audit have resulted in litigation. Attention must again be called to the fact that statutes for the various states have been interpreted by the courts in light of legislative intent, and this intent will vary with the state under consideration. Court decisions of one state often will influence the actions of another, but do not always do so.

Table $V$ is based on examination of the statutes

$$
{ }^{36} \text { Ibid. }
$$


pertaining to the conduct of general school district audits. The statutory provisions for the audit of school lunchroom accounts and stuient activity accounts are not included in this section but are discussed separately in Chapter VI. The abbreviations "Pa" and TCPA" appearing in Table $V$ stand for Public Accountant and Certified Pubiic Accountant, respectively.

In inany states tine school districts are left with a choice of the individual who inay conduct the audit. In the states of Colorado and Conrecticut the statutes allow the audit to be conducted either by the State Auditor's office or by a Certifieu Public Accountant licensed to do business in those states.

The time period between school audits varies in the several states from an annual audit to one conducted only upon the request of the district taxpayers or some state agency. Audits are required of ald cistricts in some states, while in others the, are required of only certain size districts. The table has been footnoted to clarify these situations.

beveral of the states have statutory provisions which provide for audit reports to be presented and voted on at the annual meeting. For the most part these have been mentioned only briefly, as this study is concerned prinarily with the influence of state ratier than local agencies over the financial operations of the school district.

For the state of Peinsylvania the entry in the last 


\section{TABLE V}

STATUTORY PROVISIUNS FOR AUDITING IOCAL SCHOUL DISTRICT FINANCIAL ACCOUNTSa

\begin{tabular}{|c|c|c|c|c|}
\hline State & 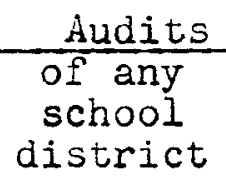 & $\begin{array}{l}\text { equired } \\
\text { of all } \\
\text { school } \\
\text { districts }\end{array}$ & $\begin{array}{l}\text { Frequency } \\
\text { of audit }\end{array}$ & $\begin{array}{l}\text { Agency conducting } \\
\text { audit }\end{array}$ \\
\hline $\begin{array}{l}\text { Alabama } \\
\text { Alaska } \\
\text { Arizona } \\
\text { Arkansas } \\
\text { California }\end{array}$ & $\begin{array}{l}\text { Yes } \\
\text { Yes } \\
\text { Yes } \\
\text { Yes } \\
\text { Yes }\end{array}$ & $\begin{array}{l}\text { Yes } \\
\text { Yes } \\
\text { Yes } \\
\text { Yes } \\
\text { Yes }\end{array}$ & $\begin{array}{l}\text { Biennial } \\
\text { Biennial } \\
\text { Annual } \\
\text { Annual } \\
\text { Annual }\end{array}$ & $\begin{array}{l}\text { State Examiner } \\
\text { State Auditor } \\
\text { State Ixaminer } \\
\text { State Comptroller or PA } \\
\text { CPA or PA }\end{array}$ \\
\hline $\begin{array}{l}\text { Colorado } \\
\text { Connecticut } \\
\text { Delaware } \\
\text { Florida } \\
\text { Georgia }\end{array}$ & $\begin{array}{l}\text { Yes } \\
\text { Yes } \\
\text { Yes } \\
\text { Yes } \\
\text { Yes }\end{array}$ & $\begin{array}{l}\text { Nob } \\
\text { Yes } \\
\text { Yes } \\
\text { Yes } \\
\text { Yes }\end{array}$ & $\begin{array}{l}\text { Annual } \\
\text { Biennial } \\
\text { Annual } \\
\text { Annual } \\
\text { Annual }\end{array}$ & $\begin{array}{l}\text { State fuditor or CPA } \\
\text { State Auditor or CPA } \\
\text { State Budget Commission } \\
\text { State Auditor } \\
\text { State Auditor }\end{array}$ \\
\hline
\end{tabular}

abbreviations "PA" and "CPA" stand for Public Accountant and Certified Public Accountant, respectively.

${ }^{b}$ Audits required if expenditures total more than $\$ 10,000.00$ per year. 


\section{TABLE V (cont.)}

\begin{tabular}{|c|c|c|c|c|}
\hline State & $\begin{array}{l}\text { Audits } \\
\text { of any } \\
\text { school } \\
\text { district }\end{array}$ & $\begin{array}{l}\frac{\text { equired }}{\text { of all }} \\
\text { school } \\
\text { districts }\end{array}$ & $\begin{array}{l}\text { Frequency } \\
\text { of audit }\end{array}$ & $\begin{array}{l}\text { Agency conducting } \\
\text { audit }\end{array}$ \\
\hline $\begin{array}{l}\text { Kansas } \\
\text { Kentucky } \\
\text { Louisiana } \\
\text { Maine } \\
\text { ifaryland }\end{array}$ & $\begin{array}{l}\text { Noc } \\
\text { Yes } \\
\text { Yes } \\
\text { Yes } \\
\text { Yes }\end{array}$ & $\begin{array}{l}\text { No } \\
\text { Yes } \\
\text { Yes } \\
\text { Yes } \\
\text { Yes }\end{array}$ & $\begin{array}{l}\text { Varied } \\
\text { Annual } \\
\text { Annual } \\
\text { Annual } \\
\text { Annual }\end{array}$ & $\begin{array}{l}\text { CPA } \\
\text { State Auditor } \\
\text { Supervisor of Accounts } \\
\text { State Auditor or PA } \\
\text { PA }\end{array}$ \\
\hline $\begin{array}{l}\text { Miassachusetts } \\
\text { Michigan } \\
\text { Minnesota } \\
\text { Mississippi } \\
\text { Missouri }\end{array}$ & $\begin{array}{l}\text { Yes } \\
\text { Yes } \\
\text { Yes } \\
\text { Yes } \\
\text { Yes }\end{array}$ & $\begin{array}{l}\text { Yes } \\
\text { Yes } \\
\text { Yes } \\
\text { Yes } \\
\text { Yes }\end{array}$ & $\begin{array}{l}\text { Annual or Bienniald } \\
\text { Annual or Triennial } \\
\text { Annual } \\
\text { Annual } \\
\text { Biennial }\end{array}$ & $\begin{array}{l}\text { Town Auditor } \\
\text { CPA } \\
\text { State Examiner or CPA } \\
\text { State Auditor } \\
\text { State Auditor or Board employe }\end{array}$ \\
\hline $\begin{array}{l}\text { Montana } \\
\text { Nebraska } \\
\text { Nevada } \\
\text { New Hampshire } \\
\text { New Jersey }\end{array}$ & $\begin{array}{l}\text { Yes } \\
\text { No } \\
\text { Yes } \\
\text { Yes } \\
\text { Yes }\end{array}$ & $\begin{array}{l}\text { Yes } \\
\text { No } \\
\text { Yes } \\
\text { Yes } \\
\text { Yes }\end{array}$ & $\begin{array}{l}\text { Annual } \\
\text { None } \\
\text { Biennial } \\
\text { Biennial } \\
\text { Annual }\end{array}$ & $\begin{array}{l}\text { State Examiner or CPA } \\
\text { None } \\
\text { PA or CPA } \\
\text { State Tax Commission or PA } \\
\text { Hunicipal Accountant }\end{array}$ \\
\hline $\begin{array}{l}\text { New Miexico } \\
\text { New York }\end{array}$ & $\begin{array}{l}\text { Yes } \\
\text { Yes }\end{array}$ & $\begin{array}{l}\text { Yes } \\
\text { Yes }\end{array}$ & $\begin{array}{l}\text { Annual } \\
\text { Annualf }\end{array}$ & $\begin{array}{l}\text { One skilled in audits } \\
\text { State Comptroller, PÁ, or } \\
\text { Committee }\end{array}$ \\
\hline
\end{tabular}

${ }^{\mathrm{c}}$ State Superintendent may audit annually.

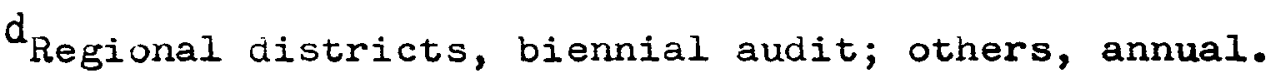

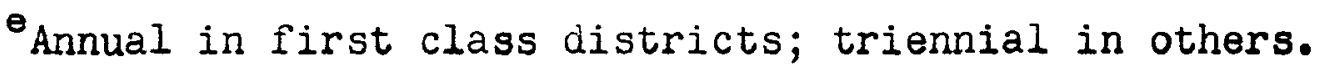

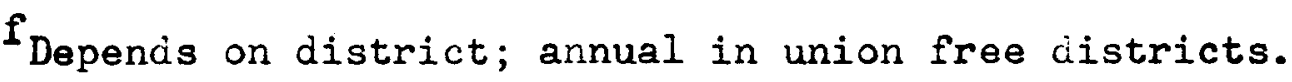




\section{TABLE V (cont.)}

Audits required

of any of all

school school

State

district

districts

Frequency

of audit

Annual
Annual
Biennial
Varied
Annual
Annual
Annual
Annual
Biennial
Biennial

Ánnual

Annual

Annual
Agency conducting

audit

North Carolina
North Dakota
Ohio
Oklahoma
Oregon

Pennsylvania

Rhode Island

South Carolina

South Dakota

Tennessee

\section{Texas}

Utah

Vermont

$\begin{array}{ll}\text { Yes } & \text { Yes } \\ \text { Yes } & \text { Nog } \\ \text { Yes } & \text { Yes } \\ \text { Noh } & \text { No } \\ \text { Yes } & \text { Yes } \\ \text { Yes } & \text { Yes } \\ \text { Yes } & \text { Nok } \\ \text { Yes } & \text { Yes } \\ \text { Yes } & \text { Nol } \\ \text { Yes } & \text { Yes } \\ \text { Yes } & \text { Yes } \\ \text { Yes } & \text { Yes } \\ \text { Yes } & \text { Yes }\end{array}$

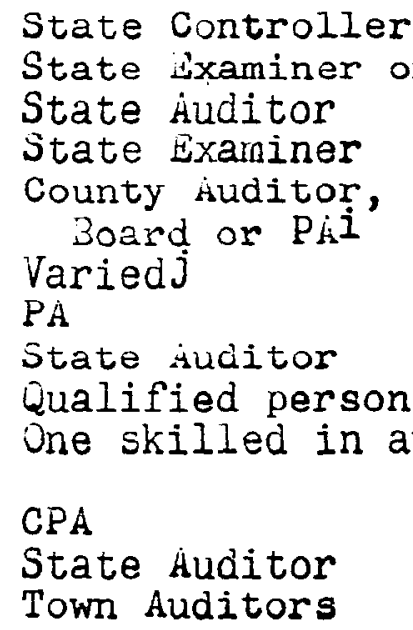

$\mathrm{g}_{\mathrm{By}}$ petition of 35 per cent of electors, or in districts over 1,000 population. Governor.

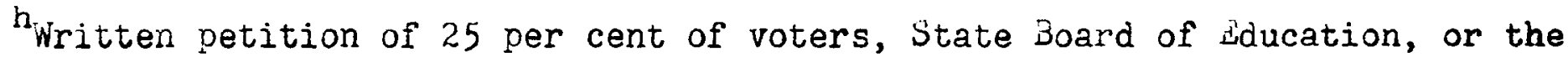

${ }^{i}$ Agency responsible depends on class of district.

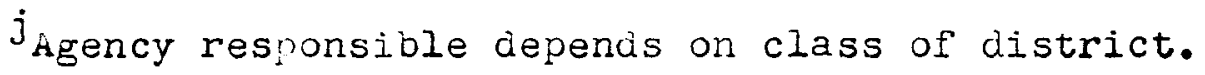

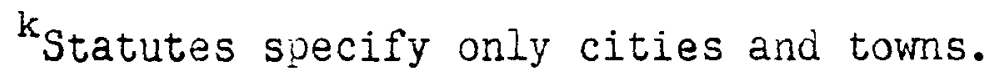

$1_{\text {At }}$ request of specified officials or by petition of 20 per cent of taxpayers in certain size districts.

$\mathrm{m}_{\text {Statutes specify towns only. }}$ 
TABLE V (cont.)

\begin{tabular}{|c|c|c|c|c|}
\hline State & $\begin{array}{c}\text { Audits } \\
\text { of any } \\
\text { school } \\
\text { district }\end{array}$ & $\begin{array}{l}\text { equired } \\
\text { of all } \\
\text { school } \\
\text { districts }\end{array}$ & $\begin{array}{l}\text { Frequency } \\
\text { of audit }\end{array}$ & $\begin{array}{l}\text { Agency conducting } \\
\text { audit }\end{array}$ \\
\hline $\begin{array}{l}\text { Virginia } \\
\text { Washington } \\
\text { West Virginia } \\
\text { Wisconsin }\end{array}$ & $\begin{array}{l}\text { Yes } \\
\text { Yes } \\
\text { Yes } \\
\text { Yes }\end{array}$ & $\begin{array}{l}\text { Yes } \\
\text { Yes } \\
\text { Yes } \\
\text { Yes }\end{array}$ & $\begin{array}{l}\text { Annual } \\
\text { Annual } \\
\text { Annual } \\
\text { Annual }\end{array}$ & $\begin{array}{l}\text { PA } \\
\text { Elected Committee } \\
\text { State Inspector } \\
\text { State Auditor or ilected } \\
\text { Committee }\end{array}$ \\
\hline Wyoming & No & No & None & None \\
\hline
\end{tabular}


column has been listed as "Varied" due to the large number of different persons who are responsible for the audit in the various types and classes of school districts under consideration.

Two states, Nebraska and Wyoming, make no nention of the general school district audit in their statutes.

Missouri has an elaborate audit law, required of all six director school districts biemially. The audit may be conducted by someone selected by the board, or it may be conducted by the state Auditor. Hither audit accepted by the board will fulfill the statutory requirement. 37

Table VI contains the same inforination as Table $V$ in sumary for.. Forty-six of the states have sone form of mandatory legislation, two states have no audit legislation, and two have legislation in winch the conduct of an audit is permissible but not mandatory.

The yearly or annual audit is used most frequently. It is conducted in 36 of the states in all or in part of the school districts. Hleven states make use of the biennial audit, and Michigan provides for a triennial audit in some of its districts.

Twenty-five states have enacted legislation which permits the audit to be conducted by a public accountant or a certified public accountant. In all states where a public

37 issouri Attorney General's Upinion, viay 20, 1957. 
TABLE VI

SUIMARY OF STATUTORY PROVISIONS ON THE AUDITING OF LOCAL SCHOOL DISTRICT FINANCIAL ACCOUNTS

No. of

states

Some form of aucit is required

Audits may be conducted

No for... of audit is required

Annual audit required of all or part of the school districts

Biennial audit required of all or part of the school districts

Triennial audit reqired of all or part of the school districts

Public Accountant or Certified Public Accountant may conduct tine audit

State Auditor may conduct the audit

Town or municipal officials may conduct the audit 6

State Pxarniner may conduct the audit 7

State Comptroller may conduct the audit 4

An elected committee may conduct the audit 2

Other agencies may conduct the audit $10^{\mathrm{a}}$

ancludes such agencies as State Tax Commission, State Budget Commission, one skilled in audits, etc. Some states. have more than one agency which may conduct the audit. 
accountant or certified public accountant is used, all insist that the person conducting the audit be licensed as an accountant in that state.

Seventeen states are required by law to have school district audits conducted by a non-educational state agency. The state auditor is the most frequently used agency. Two states, Washinton and wisconsin, have permissible legislation where an elected comittee can conduct the audit.

It is evident from the above description that the pattern for the conduct of school district general audits is varied among the several states, and also varies among classes of school districts within the states themselves. The majority of the cases brought before the courts in connection with school district audits have occurred in Pennsylvania. Wost of the cases resulted after acts of "surcharge" were brought against the school board nembers. Surcharge is defined as "An overcharge, an exaction, impost, or incumbrance beyond what is just and right, or beyond one's authority or power." 38

The audit cioes not have to be rnade within the time limits set in the statutes. In the case of viauch Chunk Tp. School Dist. v. Fisher, ${ }^{39}$ the school audit was not conducted annually as required. After a two-year period the audit was

38 Henry C. Black, Black's Law Dictionary (st. Paul: West Publishing Company, 1951 ), p. 1610 .

39 Wauch Chunk Tp. School Dist. v. Fisher, $130 \mathrm{~Pa}$. Super. 328, 197 A. 635 (1938). 
finally made. In ruling whether the audit was valid, the court said that the statute does not bar the auditors from making an audit at a later time.

The court ruled in a sinilar manner in dealing with an audit that was conducted nine months after it was due by statute. The court said:

The provisions of a statute requiring public officers to act within a specified time period are generally regarded as directory, unless time is of the essence of the thing being done, or the statute indicates that the provisions are to be rejarded as mandatory. 40

In the same case of the Scranton School District audit, ${ }^{41}$ the notice of filing of the audit by the prothonotary (the title given to an officer who officiates as principal clerk of some courts) 42 was not subnitted as the statute indicates it should be. The Pennsylvania court ruled that since the filing of the auditor's report is "for the purpose of giving notice to anyone interested or who might be affected thereby, no one in this case suffered as a result of the failure to acivertise. 143

Audits must be in detail sufficient to satisfy statutory requirements, as indicated by the Superior Court in

40 Scranton School District Audit, $51 \mathrm{~Pa}$. D.\&C. 1, 45 Loc. Jur. 193, 58 York 105 (1944).

$4{ }^{4 \text { IDid. }}$

42 Black, ㅇe. cit., p. 1388.

${ }^{43}$ Scranton School District Audit, supra. 
Pennsylvania in School Board of East Penn Tp. School Dist. v. Kemmerer et al. In this case the school district filed suit to recover a sum of money from the tax collector. The court said:

The report filed in trie instant case shows a general audit of the accounts of the school district. There is no sum specifically charged against the tax collector. In this respect it is not such a complete report as is contemplated by the act. In order to attach liability to the tax collector, the auditors should show not only a sum definitely charged against him, but also an audit of the tax collector's accounts. 44

Any money collected and used by a school district in which district properties are used directly or indirectly is public money and subjact to audit like all public funds. In one of the most important cases in which noneys were derived from extracurricular sources, the Superior Court of Pennsylvania ruled in the following manner:

Accounts of joint consoliciated school districts, created through extra curricular activities of students, such as atnletic and dramatic and musical enterprises at which adinission fees were charged, must go into official account of the district treasurer and are subject to audit.

Where moneys or properties are derived directly or indirectly through the use of school buildings, or from expenditure of public funds of the school district, the moneys thus derived are public property and must be handled the same as tax moneys and be paid to district treasurer and are suoject to public auciit. 45

${ }^{44}$ School Board of Last Penn TP. School Dist. v. Kemmerer et al., $153 \mathrm{~Pa}$. Super. 332, 44 A.2nd 845 (1945).

${ }^{45}$ Petition of Auditors of Hatfield Tp. School Dist., Appeal of Hatfield Joint Consol. School board, $161 \mathrm{~Pa}$. Super. 338,54 A. 2nd 833 (1947). 
The same action was taken by the Supreme Court of South Carolina recently in Betterson v. Stewart. 46 The Court's statement was:

The duty of jtewart to account for the funcis entrusted to his care is not in issue. He admits his duty to account and alleges his willingness to do so. His mere statement that he has properly handled the monies turned over to hin is not enough. Having assuned the duty of administering the fund entrusted to hin and admitting his duty to account, he has the duty of rendering a full anc accurate accounting of his acministration thereof, showin: a complete st:atenent of his receipts, disbursements, and any balance remaining ...47

There are several cases in which the auditor's report discovered that statutory requirements were not complied with. Host of the cises are reported in the state of Pennsylvania. The Supreme Court ruled in the case of In re Chester School District's Audit 48 that school directors are held liable for their cárelessness in not securing competitive bids while purchasing certain classes of suplies.

They wrote:

While our conclusion imposes a heavy burcien upon appellants, the court is without power to relieve them from the effort of their own carelessness or error, whatever it may de.

The duty of this court is to execute the legislative will in a manner prescribed in the statutes so long as no constitutional provision is violated, regardiess of the hardship of a particular case or whether our

\footnotetext{
$102(1961)$. 47 Ibid.

${ }^{48}$ In re Chester school District's Audit, 301 Pa. 203, 151 A. 801 (1930).
}

${ }^{46}$ Betterson v. Stewart, 233 S.C. 574,121 S.E. 2nd 
opinion as to what the law ought to be coincides with that of the Legislature. 49

The renoval of the school directors from office was upheld, but judgments against the individuals were reversed in favor of the directors. Even if the school district feels that the matarials it purchases are best, it must secure bids. 50

The language above is taken from an earlier Pennsylvania case, Audit of Hanover Tp. School Dist., appeal of ijorris, et al., 51 which was decided by the Suprene Court in which similar charses of surcharge were brought against the board of sciool directors winen they failed to secure bids for the purchase of libriry books, as well as bias for repairing the school building and school grouncis.

The actions of the Pennsylvania court becane less stern when they tried the school directors of Premont Township school in the case of In re Treinont Township School Directors. 52 The directors were not renoved froin office on the basis of the following opinion ui the court:

... The court should not avail itself of the power to remove these elected of icials unless it is convinced tinat the technical violations of the mandate
${ }^{49}$ Ibia.
50 Ibid.

$51_{\text {Audit }}$ of Hanover Tp. School Dist., Appeal of Viorris, et al., $256 \mathrm{~Pa}$. 157, $108 \mathrm{~A} .656$ (1919).

52 In re Tremont Township School Directors, $34 \mathrm{~Pa}$. D. ¿C. 632 (1938). 
of the school code have been motivated by an intent to defraud or corrupt, or that violations have resulted in financial loss to the school district. Violations which result from mistaken judgment on the part of the directors anc which have not caused harm to the taxpayers of the district in any nanner should not be punished in so drastic a manner as envisioned by this act. 53

In another Pennsylvania case, in wilch the school directors of Gerinan Towiship were broujint to trial, 54 the above action of the court was followed when an error in judgnent in failing to secire bicis a second tine after the original supplier defaulted for failing to secure proper sureties to back up nis original quotation. The board was tried also for allowing a bill of $\$ 965.30$ to be paid to the Dice-Spauliing Company for the purchase of athletic equipment without securing bids. The board of school directors turned over the control and managenent of athletics to a separave boara. They set up this separate board under the jchool Cocie of vay 18, 1912, P. J. 30\%, wilicin states:

The board oi school diractors in every school district of the first and second class shall, and in every district of the thiru and fourth class, may, prescribe, adopt, and enforce sucin reasonable rules and regulations as it may deen proper, regarding the managenent, control, or prohibition of exercises, atiletics, or games of any kind, taken part in or played by any pupils as mentivers of or in connection with any public school.

The court interpreted the above section of law as follows:

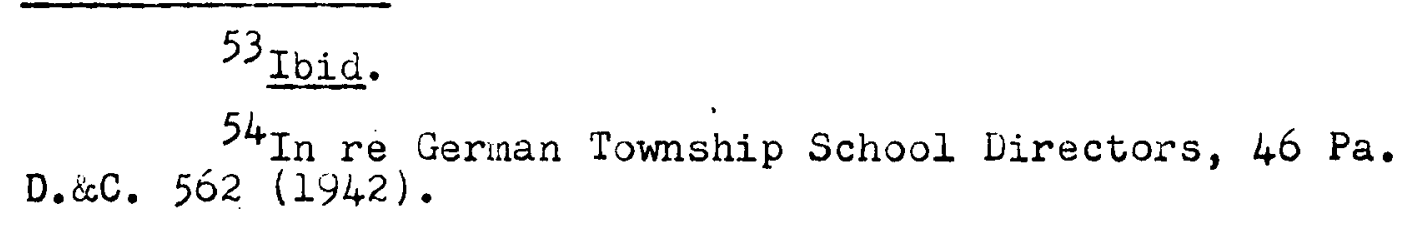


The language of this section in no sense serves to divorce the athletic and musical organizations of the high school from other departinents of the public schools ....

The school board inay hereafter continue to permit the athletic board of control to manage and direct extra curricular activities, but all moneys received therefrom anci all expenditures for equipment to be used therein must be reported to ana approved by the board of directors as a board. 55

From the above cases it seens that if an error of judgment on the part of the board of education is male which does not prove to be an act to cierraud and does not result in financial loss to the school district, the actions of the board may be forgiven. If, however, an act can be proven to be corrupt, school board inenbers nay be removed from office and held liable for their actions.

\section{SUIVIVIARY}

The extensive legislation dealing with the financial administration of local school districts indicates a primary concern by state legislatures for the honest and econonical operation of schools. The effect of much of this legislation is to impose linitations on the independence of local school authorities in financial wanagienent. These limitations are exercised through (I) specific provisions of statutes, and (2) through the actions of state ajencies which are authorized by the legislature to supervise or approve or otherwise

\section{${ }^{55}$ Ibid.}


similarly limit the freedom of action by local boards and officials in the fiscal affairs of schools.

1. Statutory provisions in each of the 50 states require the prescription of a uniform financial accounting system for school districts. Use of the prescribed accounting systems may be mandatory, director $f$, or optional with local school districts in the various states. In some of the states, requirements for the use of a unifor accounting system may vary among sizes, classes, or categories of school districts.

2. As part of its uniform system of accounting, each of the stetes imposes some sort of requirement for the construction of a local school district budget. Statutory provisions with respect to the detail in which the budget must be prepared and adniniutered vary considerably among the states. ivore than one-half of the states require that the local school budiget must be approved by either a local or state non-educational agency in some or all of the local school districts.

3. Consicierable litigation has developed in the various states over the interpretation of the statutes dealing with the adninistration of local school budgets. Wnen the language of statutory provisions is clear, these prevail. Where the meaning is less certain, the courts have tended to regard the public interest as paramount in interpreting doubtful provisions. Local school boards are required to 
operate within statutory limitations, but beyond specific requirements the courts have tended to approve school board action which they regara as "reasonable ana just." Boards generaily are peritted considerable latitude in deteraning local financial olicy, but school boards and school board members may be held liable for fraud, corruption, or other improper use of school funcis.

4. Forty-six states have some form of manciatory legislation requiring an audit for at least part of the school districts within the state. Adout one-half of the states permit the local board of education to enjloy an accountant of their own choice to make the audit. The remainder of the states require the audit to be made by some non-educational agency, most frequently the state auditing agency. Usually audits are required on an annual basis, but a few states pernit biennial or triennial audits. 


\section{CHAPTER IV}

\section{THE CONSTRUCTIUN OP SLHUOL BUILDINGS}

The planning and erection of school buildings has long been consiciered an enterprise of the local cormunity, but due to the nation's changing econony, local connunities are finding it difficult to replace old buildin;s with new ones. More and more, local communitias have come to look toward the state and federal governments for financial support in the erection of schools.

In 1952 the Cooperabive Prosra:a in Educational Adininistration, ${ }^{I}$ financed by the W.K. Kellogg Foundation, reported that 26 or the 48 states have sorne form oi financial aid from the state for school construction. Since then, several other states have enacted logiulation perritting the state to help with the financing of school conistruction.

This chapter is concerned with the controls exercised by the 50 states in the construction and repair of school buildinfs. Wheir state funcis are involved in the construction of school buildin!s, the state has an aditional interest in the protection of funds. State regulation of school building

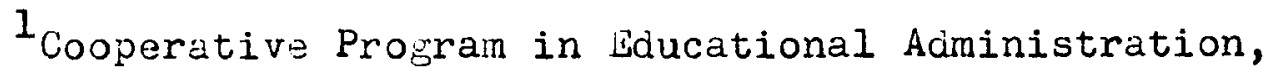
Educational Consultants and their Work in Widwestern State Departments of Education (vitidwestern Administrative Center, University of Chicago, 1952). 
finance extends also to the use of local funds. The controls with which this section deals are concerned with the approval of plans and specificutions by some state agency in addition to the local school board. This naf be either an educational or a non-educational agency. This chapter is concerned also with the degree to which local school districts must conform to state and local building regulations and inspections.

This chapter furtier exanines the statutory provisions in states were school districts must subait their plans and specifications ts soine a ency in orcier to qualify for special state building aic construction funcs.

\section{STATUTORY PROUISIJNS GOVERINING THE APPROVAL OF PLANS AND SPECIPICATIONS FOR SCHOUL CONJTRUCTION}

This section is concerned with the following questions relating to the approval of plans and specifications of local scnool building construction:

1. Which of the 50 states have statutory provisions requiring the approval of building plans before construction can begin?

2. What agency must aprove plans and specifications in those states requiring approval?

3. What agency is responsible for the construction of building regulations and the conduct of building inspections?

4. Which of the statutory provisions are mandatory on the part of the locial sciool district.

Table VII presents an anaiysis of the statutory provisions governinio the approval of building plans and specifications in the 50 states. Approval procedures vary from 
TABLE VII

STATUTORY PROVISIONS GOVERNING THE APPRUVAL OF BUILDING PLANS AND SPECIFICATIUNS FO:2 SCHOOL CONSTRUCTIUN

\begin{tabular}{|c|c|c|}
\hline State & $\begin{array}{l}\text { State approval } \\
\text { of plans required }\end{array}$ & $\begin{array}{c}\text { State agency } \\
\text { making apiroval }\end{array}$ \\
\hline $\begin{array}{l}\text { Alabana } \\
\text { Alasira }\end{array}$ & $\begin{array}{l}\text { No } \\
\text { Yes }\end{array}$ & $\begin{array}{l}\text { None } \\
\text { State Dept. of Adninis- } \\
\text { tration }\end{array}$ \\
\hline $\begin{array}{l}\text { Arizona } \\
\text { Arkansas } \\
\text { California }\end{array}$ & $\begin{array}{l}\text { No } \\
\text { Yes } \\
\text { Yes }\end{array}$ & $\begin{array}{l}\text { None } \\
\text { State Board of Education } \\
\text { State Dept. of Educationa }\end{array}$ \\
\hline $\begin{array}{l}\text { Colorado } \\
\text { Connecticut } \\
\text { Delaware } \\
\text { Florida } \\
\text { Georgia }\end{array}$ & $\begin{array}{l}\text { Yes } \\
\text { Yes } \\
\text { Yes } \\
\text { Yes } \\
\text { Yes }\end{array}$ & $\begin{array}{l}\text { State Board of Education } \\
\text { State Board of Education } \\
\text { State Board of Education } \\
\text { State Superintendent } \\
\text { State School Building } \\
\text { Authority }\end{array}$ \\
\hline $\begin{array}{l}\text { Hawaii } \\
\text { Idaho } \\
\text { Illinois } \\
\text { Indiana } \\
\text { Iowa }\end{array}$ & $\begin{array}{l}\text { Yes } \\
\text { Yes } \\
\text { Yes } \\
\text { Yes } \\
\text { No }\end{array}$ & $\begin{array}{l}\text { State Dept. of Education } \\
\text { State Board of iducation } \\
\text { State Building Commission } \\
\text { State Board of Education } \\
\text { None }\end{array}$ \\
\hline $\begin{array}{l}\text { Kansas } \\
\text { Kentucky } \\
\text { Louisiana } \\
\text { Maine } \\
\text { Maryland }\end{array}$ & $\begin{array}{l}\text { Yes } \\
\text { Yes } \\
\text { No } \\
\text { Yes } \\
\text { Yes }\end{array}$ & $\begin{array}{l}\text { State Architect } \\
\text { State Superintendent } \\
\text { None } \\
\text { State Comnissioner } \\
\text { State Superintendent }\end{array}$ \\
\hline $\begin{array}{l}\text { Massachusetts } \\
\text { Wichigan } \\
\text { Minnesota } \\
\text { Wississippi } \\
\text { Missouri }\end{array}$ & $\begin{array}{l}\text { No } \\
\text { Yes } \\
\text { Yes } \\
\text { Yes } \\
\text { Yes b }\end{array}$ & $\begin{array}{l}\text { None } \\
\text { State Superintandent } \\
\text { State Dept. of Iducation } \\
\text { State Educational Fi- } \\
\text { nance Connission } \\
\text { State Board of Education }\end{array}$ \\
\hline
\end{tabular}

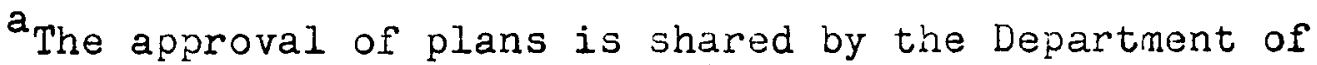
Education and the State Division of Architecture.

${ }^{b}$ Applies to certain class districts only. 
TABLE VII (cont.)

\begin{tabular}{|c|c|c|}
\hline State & $\begin{array}{l}\text { State approval } \\
\text { of plans required }\end{array}$ & $\begin{array}{l}\text { State agency } \\
\text { making approval }\end{array}$ \\
\hline $\begin{array}{l}\text { Montana } \\
\text { Nebraska } \\
\text { Nevada } \\
\text { New Hampshire } \\
\text { New Jersey }\end{array}$ & $\begin{array}{l}\text { Yes } \\
\text { No } \\
\text { Yes } \\
\text { Yes } \\
\text { Yes }\end{array}$ & $\begin{array}{l}\text { State Board of Health } \\
\text { None } \\
\text { State Planning Board } \\
\text { State Board of Liucation } \\
\text { State Board of Sducation }\end{array}$ \\
\hline $\begin{array}{l}\text { New Vexico } \\
\text { New York } \\
\text { North Carolina } \\
\text { North Dakota } \\
\text { Ohio }\end{array}$ & $\begin{array}{l}\text { Yes } \\
\text { Yes } \\
\text { Yes } \\
\text { Yes } \\
\text { Yes }\end{array}$ & $\begin{array}{l}\text { State Board of Education } \\
\text { State Commissioner } \\
\text { State Superintendent } \\
\text { State Superintendent } \\
\text { State Dept. of Finance }\end{array}$ \\
\hline $\begin{array}{l}\text { Oklahoma } \\
\text { Oregon } \\
\text { Pennsylvania } \\
\text { Rhode Island } \\
\text { South Carolina }\end{array}$ & $\begin{array}{l}\text { Noc } \\
\text { No } \\
\text { Yesb } \\
\text { Yes } \\
\text { No }\end{array}$ & $\begin{array}{l}\text { State Board of Education } \\
\text { None } \\
\text { State Dept. of Education } \\
\text { State Superintendent } \\
\text { None }\end{array}$ \\
\hline $\begin{array}{l}\text { South Dakota } \\
\text { Tennessee } \\
\text { Texas } \\
\text { Utah } \\
\text { Verinont }\end{array}$ & $\begin{array}{l}\text { Yes } \\
\text { Yes } \\
\text { Noc } \\
\text { Yes } \\
\text { Yes }\end{array}$ & $\begin{array}{l}\text { State Superintendent } \\
\text { State Fire larshal } \\
\text { State Comnissioner } \\
\text { State Superintendent } \\
\text { State Board of Health }\end{array}$ \\
\hline $\begin{array}{l}\text { Virginia } \\
\text { Wastington } \\
\text { West Virginia } \\
\text { Wisconsin } \\
\text { Wyoming }\end{array}$ & $\begin{array}{l}\text { Yes } \\
\text { No } \\
\text { Yes } \\
\text { Yes } \\
\text { No }\end{array}$ & $\begin{array}{l}\text { State Board of Education } \\
\text { None } \\
\text { State Superintendent } \\
\text { State Industrial Com- } \\
\text { mission } \\
\text { None }\end{array}$ \\
\hline
\end{tabular}

${ }^{c}$ State educational authorities furnish plans on request. 
written approval of the state board of education, as in Connecticut and Delaware, to no required approval at all, as in Arizona and Iowa.

In several states, approval of plans is reserved for special districts of a certain class or size. This is true of Missouri, Pennsylvania, and ivew York.

Twelve states do not require state agency approval of building plans and specifications: Alabama, Arizoria, Iowa, Louisiana, Niassachusetts, Nebraska, Oklahoma, Oregon, South Carolina, Texas, Washinjton, and Wyoming. The states of Oklahoma and Texas furnish building plans made by the State Departnent of Education to local school boards on request. The state of California requires building plans to be approved by both the State Departinent of Education and the State Department of Architecture.

Table VIII presents the same information as Table VII in summary form. Thirty-eight states require some form of state agency approval of building plans and specificutions in all or part of the school districts.

Or tiese 38 states, 27 have ploced this responsibility with the educational authorities of the state. In the 11 states that require approval by an ajency other than the state educational authorities the distribution is as follows: three have placed it with the state departilent of building and planning (Georgia, Illinois, Nevada); two with the state board of health (Hontana, Vernont); two with the state 


\section{TABLE VIII}

SUMMARY OF STATUTORY PROVISIUNS GOVERINING THE APPROVAL OF PLANS AND SPISCIFICATIONS FOR LOCAL SCHUOL BUILDING CONSTRUCTION

No. of states

Some form of state agency approval required for plans in all or part of the school districts

Approval of plans by some agency not required

Approval of plans by the state educational authorities in all or part of the districts

12

27

State Department of Building or Planning permitted to approve plans in all or part of the school districts

State Department of Architecture may approve plans in all or part of the school districts

2

State Department of Health inay approve plans in all or part of the school districts

2

State Department of Finance may approve plans in all or part of the school districts

2

State Fire viarshal may approve plans in all or part of the school districts

1

Other state agencies permitted to approve plans in all or part of the school districts 
department of finance (Hississippi, Ohio); one each with the state department of architecture (Kansas), state fire marshal (Tennessee), state industrial commission (Wisconsin), and the state departnent of administration (Alaska).

Building Regulations and Inspections

In many instances where school district boundaries lie within the confines of a city, the question often arises whether school districts constructing buildings are required to conform to local or municipal buildin regulations. Roach sumnarized compliance with municipal cocies in two legal principles:

The power of a school district being linited to the education of children, its authority with regard to the erection of a school building, the operation of heating facilities, or the operation of a school cafeteria, may be subjugated to the municipal police power to naintain the safety, health, anc seneral welfare of the municipality's entire population.

The authority in such areas of joint municipalityschool district concern as fire protection in the construction and operation of a school building, or the inspection and regulation of school cafeterias (with regard to food, utensils, waste disposal, health, and cleanliness of food hancilers, etc.) will lie with the agency to which the le jislature has pranted the applicable specific regulatory powers. 2

The writer will compare his data collected on compliance with building codes to Roach's legal principles.

2 Stejhen F. Roach, "Compliance with Vunicipal Codes," The American School Board Journal, CXXIIX (September, 1959), 51 . 
The attorney generals of some states, such as Michigan, have ruled that municipal building regulations do not apply to local school construction. One opinion states:

The legislature has placed complete control of construction of school buildins in the superintendent of public instruction and the state fire marshal, and the legislature has conferred no authority upon home rule cities to require building permits, inspections and fees from local school districts. 3

The attorney general of ilinnesota, however, has stated that in that state "Local building cocies apply to new construction, " 4 which includes school buildin s.

Table IX presents an analysis of the statutory provisions regarding building regulations and inspections. The table indicates those states which have a set of building regulations and the agency responsible for their prescription. No attempt has been made to list the applicable building regulations in detail, since the present study is concerned only with the existence of such regulations and identification of the agency which prescribes them.

In some states nore than one agency is responsible for building regulations and inspections to which school districts must achere. These have been listed in the table where the responsibility is a shared one.

\footnotetext{
3 Michican Attorney General's Opinion, No. 3156, January $9,1959$. See also FIorida Attorney General's Opinion 058-119 and 062-41. $9-1958$. HNinnesota Attorney General's Opinion, No. 59-A-
} 
TABLE IX

STATE AGENCIES HAVING BUILDING REGULATIONS OR INSPECTIONS FOR ALL OR PART OF THE SCHOOL DISTRICTS WITHIN THE STATE

State

State agencies responsible for building regulations or inspections of local school construction

Alabama
Alaska
Arkansas
California
Colorado
Connecticut
Delaware
Florida
Georgia
Hawaii
Idaho
Illinois
Indiana
Kansas
Kentucky
Waine
Waryland
Nichigan
Mississippi
Montana
Nebraska
New Hampshire
New Jersey
New York
North Carolina
North Dakota
Ohio
Oklahora
Pennsylvania
Rhode Island

State Board of Education

State Superintendent of Public Works

State Board of Education

State Division of Architecture

State Commissioner of Public Works

State Boards of Fire and Health

State Board of Sducation

State Boards of iducation and Health

State School Building Authority

state Department of Public Works

State Boards of Educational and Public Welfare

State Boards of Education, Health, Fire, and Architecture

State Commission on General Education

State Architect

State Superintendent

State Departments of iducation and Health

State Boards of iducation and Public Improvements

State Superintendent and State Fire ivarshal

State Iducational Finance Commission

State Board of Health

State Fire Warshal

State Board of Health

State Board of Education

State Commissioner and Superintendent of Public Works

State Fire Warshal

State Superintendent

State Board of iducation

State Board of iducation

State Departient of Education

State Superintendent 
TABLE IX (cont.)

State agencies responsible for building regulations or inspections of local

State school construction

South Carolina

South Dakota

Teinessee

Texas

Utah

Vermont

Virginia

West Virginia

Wisconsin

Wyoming
State Finance Commission

State Superintendent

Stace Fire varshal

State Conmissioner

State Superintencient

State Board of Health

State Board of Lducation

State Superintendent and State Fire iviarshal

State Inciustrial Conmission

State Boards of Education and Health 
Eleven states --Arizona, Georgia, Iowa, Louisiana, ivassachusetts, Viinnesota, IVissouri, Nevada, New Mexico, Oregon, and Washington-- do not require conformance with a state-prescribed set of regulations. As mentioned earlier, some of the stutes in this group, as well as those requiring compliance with state-prescribed regulations, must conform to local or municipal building cocles.

Table $X$ presents the same information as l'able IX in summary forra. Thirty-nine states require conformance to some form of prescribad building regulations or inspections. Several states --California, Illinois, and North Lakota, to name a few-- have building regulations for school construction printed as statutory rovisions. This is true of several other states referred to.

The responsibility for the prescription of building regulations is shared by several departments in some states. In Cornecticut it is shared by the state boards of fire and health, while in Illinois the state departments of education, health, and fire prepare specifications.

Of all the non-educational agencies resonsible for the prescription of building regulations, the state board of health is used most frequently; Connecticut, Florida, Illinois, Vaine, Hontana, Wew Hampsire, Vermont, anc Wyoming use that agency. Seven states perinit the state fire marshal or his department to help in the prescription of building regulations or the making of inspections; these states are: 


\section{TABLE X}

SUMMARY OF STATUTORY PROVISIONS GOVERNING

THE PRESCRIPTION OF BUILDING REGULATIONS

APPLICABLE TO LOCAL SCHOUL CUINSTRUCPIONa

No. of

States

Use of state building regulations required

Use of building regulations not required

State educational authorities permitted to prescribe building regulations

State fire marshal permitted to help in the prescription of building regulations

State department of health permitted to help in the prescription of building regulations

State department of public works permitted to help in the prescription of building regulations

State departiment of architecture perinitted to help in the prescription of building regulations

Other state agencies permitted to help in the prescription of building regulations

a Several states have placed this responsibility with two or more state agencies. 
Connecticut, Illinois, Michigan, Nebraska, North Carolina, Tennessee, and West Virginia.

Applicable Court Decisions

Court decisions are resented in this section that deal with questions relating to the approval of school building plans and specifications.

Compliance with statutory provisions requiring the approval of building plans was deened nandatory in the case of Morse v. Inhabitants of 'Pown of Wontville. ${ }^{5}$ Worse filed an action in assumpsit in which he sought to recover damages for the materials he sold to the superintendent of schools for the construction of a school house. The superintencient, acting as the agent for the school comittee, proceeded to erect a building without submitting the plans and specifications to the state suprintendent as required by statutes. In addition, the school comnittee decided to erect the local school on a site uifferent froti that voted on by the district electorate. In discussing the action of the connittee, the Naine supreme Court stated:

As no plans and specifications were furnished by the state to be used in the construction of said schoolhouse, the superintending school cominittee had no authority to erect or construct a schoolhouse until they had made plans and specifications for such proposed school building and had submitted them to and had them

Siviorse v. Town of ivontville, 115 vo. 454, 99 A. 438 
approved by the state superintendent of public schools, and the State Board of Health. 6

The Court also ruled on the actions of the superintendent and the school comnittee with regard to purchasing the necessary equipnent, as well as on the actions of Morse who sold the equipment to the superintencient and filed this suit. The Court said:

The superintending school connittee and superintendent of schools had no authority from the town to build a schoolhouse, except as they proceeded according to law, and as the erection of the schoolhouse was not according to law, but in violation of the statute, they had no authority to bind the town for building materials used by them in their illegal act, for all persons furnishing materials to town or city officers must take notice at their peril of the extent of the authority of such officers.

It was their duty, before they furnished labor and materials on the credit of the town, to examine and see if the parties with whom they were contracting were authorized by law to make the contracts. If they had done so in this case, the plaintiff would have discovered that the superintencient of schools had no right to order goocis upon the credit of the town.?

In the New Jersey courts the question arose as to whether a school board has the right to withhold information supplied by the approving state agency in regard to proposed construction. $^{8}$ The people of the borough of Eeinarest voted in a legal election to issue school boncis in the amount of $\$ 290,000.00$ for the construction of a building. Soon after

\section{${ }^{6}$ Ibid. \\ 7 Ibid.}

8 Robert H. Sinith et al. v. The Board of Education of the Borough of Demarest, 35 N.J. Super. 82,113 A. 2nd 187 (1955). 
the plans were approved by the local board and submitted to the State Departinent of Education for their approval as required by statute, this action was filed three days before a special election to spend the bond noney was to be held. The action, filed $b_{J}$ resident taxpayers, charged that the school board members and school officials were in possession of important infornation from the State Board of ducation which would materially affect the proposed school. The letter written by the State Board of Education was submitted as evidence; it read:

... As these revisions are of such a nature that the general plan of the building is not affected, there should be no reason that the Board of iducation should not continue its prograin of public information and the holding of a referendum on the proposal.9

The court ruled that the board should proceed with the special election to secure the necessary funis for construction. As indicated above, New Jersej requires the approval of building plans by the state Lepartinent of Education. In a recent case the municipal government was trying to force compliance with the local building code, even though the plans and all changes in them were approved by the state Board of Education. The State Board also had made periodic inspections of the construction. The court ruled:

I conclude that the Legislature with respect to plans and specifications for public school buildings has

${ }^{9}$ Ibid. 
preempted the field. The Legislature has provided that the plans and specifications must be approved by the State Board of Education and need not be filed with the municipality nor a perait obtained. I conclude that the plans and specifications thus approved are the ones with which the building contractor must comply.10

A New Jersey court also has ruled thet, even though

the statutes provide for the approval of building plans by

the State Department of Education, individuals working on school construction must hold valid licenses for master plunbers under city ordinances. ${ }^{11}$ The court stated:

It does not appear that the Legislature intended an exception in a public school where it is even more necessary that the master plunbers and electricians should be skilled than an ordinary building. The whole trend of the statute is obviously to secure a building which shall be safe for the children, and the Legislature did not intena an exception whereby a man might do master plumbing or electrical work and not have a license therefor, merely because the work is on a school building. 12

The court here interpreted the statute in the light of securing the maximum amount of safety and health for the children of the state.

Cases from several other states indicate that the courts are not consistent in their interpretation of the police powers of municipalities to invoke building regulations on school districts constructing school houses.

10 ivartin J. Kaveny v. Board of Commissioners of the Town of Wiontclair, 69 N.J. Super. 94, 172 A. 2nd 536 (1961).

11 Board of Health of City of Plainfield v. Charles Simken and Sons, Inc. et al., 10 N.J. Super. 301, 76 A. 2nd $302(1950)$.

\section{Ibid.}


In an early California case the school district of the city of Pasadena was in the process of constructing a $\$ 400,000.00$ school building without having subinitted the plans to the municipal authorities to secure a building permit; the city police threatened to arrest the school officials and the contractor unless they secured the necessary permit. ${ }^{13}$ The California Supreme Court ruled that the municipal government had the right to invoke police power to compel the school district and the contractor to comply with municipal building regulations. The Court's reasoning was:

School districts are quasi-municipal corporations of the most limited power known to law. Their trustees have special powers and cannot exceed the limit .... Power in the school trustees to deteraine for themselves all matters concerning the school structure to be erected to the exclusion of the right of the municipality to impose police regulations cannot be implied from a grant solely of power to control school affairs of the district and plan and build school houses.

The mere fact that the school district embraces a part of a city where building regulations are imperative for public safety could afford no reasonable excuse why, if it is necessary to construct a school building in the city, the trustees should not, in the interest of the public good, be suijject to the same building regulations as others erecting structures therein are subjected to. In pronoting the municipal welfare anci safety the school district ought to be subject to them. 14

\footnotetext{
13 Pasadena School District et al. v. City of Pasadena, 166 Cal. 7, 134 P. 985 (1913).

${ }^{14}$ Ibid.
} 
In a later California case ${ }^{15}$ the Supreme Court reversed this ruling. In this later case the city of Taft was being forced to comply with city builaing regulations when this suit was filed. Although the section of the State Constitution interpreted by the court in the early case as giving the municipality the ri,ht to invoke police power remained substantially the sarne, the Court in 1 y56 stated of the Pasadena case ruling:

School districts are agencies of the state for the local operation of the state school system.

Section 11, Article 11 of the State Constitution, supra, should not be considered as conferring such powers on local governrent agencies.

Pasadena School District v. City of Pasadena ... fails to consider the factors above mentioned and insofar as jt is inconsistent with this opinion it is overruled. 16

The statutory provisions since 1913 have placed approval of building plans in the hancis of the departments of education and architecture. jchool building plans must be $a_{i}$ proved by these state departinents before construction can begin. In this later case, the Court decided that education has become a state function and the state "has completely occupied the field by general laws." 17 The stute is responsible for the approval of building plans, and the municipality is an agent of the state.

${ }^{15}$ Guy Hall v. City of Taft, 47 Cal. 2nd 177, 302 P. 2nd $574(1956)$.

${ }^{16}$ Ibid.

17 Ibid. 
The Supreme Court of Utah also ruled that the city did not have the power to invoke police regulations with regard to compliance with municipal building regulations. In describing the course of action that could be taken by citizens and taxpayers if a school building was constructed that was unsafe, the Court said:

If, however, a school board should atteupt to construct a school building of improper, unsafe, or inflammable materials, or so near to another building, public or private, as to make the school building a menace or a danger to such other buildings, either the city or the owner of the building thus menaced or enclangered, or any interested person, would have a speedy and adequate remedy in a court of equity to have the school building declared a nuisance and have it made safe or removed. From a consideration of all the various provisions relating to public schools, therefore, we are forced to the conclusion that it was not intended to invest cities with any power over school buildings except in case such buildings should become a menace and a danger as before stated, and that school boards are not required to obtain permits from the cities as contended by respondent's counsel.18

The ruling that the municipal government is but an agent of the state and governs in a linited manner was made in a Kentucky case where the city of Louisville instituted an action to compel a state-owned school to comply with a city ordinance to install fire escapes in buildinøs over three stories high. 19

The Supreme Court of Missouri held that the school

${ }^{18}$ Salt Lake City v. Board of Education of Salt Lake City et al., 52 U. 540, 175 P. 654 (1918).

19 Kentucky Institution for Education of Blind $v$. City of Louisville, $123 \mathrm{Ky} .767,97$ S.W. 402 (1906). 
district was compelled to pay inspection fees of various school building facilities in the exercise of the city's police power. 20

APPROVAL OF BUIZDING PLANS IN RELATION TO ELIGIBILITY FOR SPECIAL STATE AID FOR SCHOUL CONSTRUCTION

Several states have enacted statutory provisions to give financial assistance to scrool districts for school construction. This section of the chapter examines statutory provisions in the states having special school construction aid with respect to approval of school district plans to meet eligibility for funcis.

Thirty-eight states have some form of approval required before school districts become eligible for state construction funds. Table XI examines the statutory provisions to locate which agencies are responsible for the approval of plans to secure schosl construction funds.

In Alabama and Washington the required approval is made by the county school superintendent. The Viaryland statutes provide for a minimum tax levy to be made by school districts before they can qualify for state construction aid. In Virginia tine approval of plans to qualify for construction aid is optional with the State Board of Iducation. of the 36 states requiring mandatory approval of

$20_{\text {Kansas City }}$ v. School District of Kansas City, 356 Mio. 364,201 S.W. 2nd 930 (1947). 
TABLE XI

STATE AGENCIES APPROVING PLANS IN ORDER TO QUALIFY FOR STATE CONSTRUCTION AID

State

State agency making approval

Alabama

Alaska

California

Colorado

Connecticut

Delaware

Florida

Georgia

Hawaii

Illinois

Indiana

Kansas

Kentucky

Maine

Maryland

Vichigan

Ninnesota

Mississippi

Missouri

Nevada

New Hampshire

New Jersey

New Mexico

New York

North Carolina

North Dakota Ohio

Oklahoma

Pennsylvania

Rhode Island

South Carolina

South Dakota

Texas

Utah

Vermont
County Superintendent of Schools

State Superintendent of Public Works

State Division of Architecture

State Board of Education

State Board of Education

State Board of Bducation

State Board of Education

State School Building Authority

State Department of Education

State Building Commission

State School Planning Division

State Architect

State Superintendent of Public Instruction

State Commissioner of Education

A minimum tax levy required

State Superintendent of Public Instruction

State Board of Education

State Educational Finance Conmission

State Board of Education

State Board of Education

State Board of iducation

State Board of Education

State Board of Education

State Comnisioner of Education

State Superintendent of Public Instruction

State Board of Education

State Board of Education and State Department of Finance

State Board of Education

State Department of Public Instruction

State Board of Education

State iducational Finance Comrnission

State Board of Education

State Board of Education

State Board of iducation

State Board of Education 
TABLE XI (cont.)

State State agency making approval

Virginia

Washington

tate Board of Education

West Virginia

County Superintendent of schools

Wisconsin

Wyoming

State Board of Education may require

State Industrial Commission

State Board of Education and state Farm Loan Board 
building plans for qualification to receive funds, 27 require the approval to be made by the state educational authorities.

The Ohio State Board of Education shares the approving of plans with the State Department of Finance, and the Wyoming State Board of Education approves plans with the help of the State Farm Loan Board.

In the remaining nine states requiring state agency approval for state building funds, the responsibility is given to the state planning or building commission in Georgia, Illinois, and Indiana. The State Division of Architecture performs this function in California and Kansas. School districts of Mississippi and South Carolina submit their plans to the state educational finance commissions, while Alaska school districts submit theirs to the Superintendent of Public Works, and Wisconsin to the State Industrial Commission.

In the 38 states requiring agency approval for qualification of state school construction aid, the plans must be submitted by all or part of the school districts.

Several states do not require approval of plans by some agency when special state aid funcis will not be used for construction, but do so when the districts request to use these special funds. Among these states are: Alabama (county school superintendent), Texas (State Board of iducation), Washington (county school superintendent), Wyoming State Board of Education and State Farm Loan Board), Oklahoma 
(State Board of Education), and South Carolina (State Educational Finance Commission).

\section{Applicable Court Decisions}

School districts have been successful in mandanus proceedins to secure state aid from state asencies when the funds in question have been general school district aid. This woulc be funcis appropriated to school districts on an ADA (averaze daily attendance), ADi\% (average daily merabership), or whatever other formula is used for the distribution of state general aid funds. 21

This has not been the case where school districts have brouisht manciarnus proceedings against agancies responsible for the distrioution of special school construction aid funcis. In 1952 the State Iducational Finance Cominission of South Carolina ras sued by two schjol boarcis to compel the Conmission to appropriate funus for a new hish school. 22

The statute involved orovicied that the Commission could not disburse funcis for construction purposes unless the county boards involved in a consoliciation of districts agreed to

21 Board of iducation of City of Iron jountain v. Volker, 271 ich. 207, 259 i... $391(1 \neq 35)$. See also Indepencient school District vo. I v. Common School District No. 1 et al., 56 Idiaho 426, 55 P. 2nd 144 (1936).

22 Powers et al. v. State Educational Finance Commission et al., supra; edwarcis et al. v. State iducational Finance Commission et al., 222 S.C. 455,73 S.E. 2nd 456 (1952). 
the consolidation. In both cases one of the two county boards disapproved of the location of the proposed building. The court ruled in favor of the Comission's not appropriating the funcis on the grounos that the Commission "is not empowered to nake a consoliciation where either county board of education refuses to agree thereto." 23 During 1952, six school districts in South Carolina consolidated into a unified district with the Fairfield County Board of Education as the governing board of the entire district. The Board requested from the State Educational Finance Connission funds for the construction of a new high school. The Cornmission refused to appropriate the funds, and this suit of mandamus to compel the Connission to appropriate the funcis requested followed. ${ }^{24}$ At the time the action was filed, the Commission had not approved the proposed building plans, as required by statute in order to qualify for special. state building construction aid. Instead of approving the plans and appropriating the funds, the Commission appointed a survey comnittee to ascertain if the proposed high school was the most economical and feasible plan to follow. The survey report indicated that the

${ }^{23}$ Ibid.

${ }^{24}$ R.W. Thomas et al. v. L.P. Hollis et al., 232 S.C. 330,102 S.E. 2nd 110 (1958). 
most desirable plan to follow was to erect a new elementary school building and renovate an old school plant for use as a high school. This would result in considerable saving to the taxpayers of the district. The South Carolina Supreme Court ruled that in refusing to apuropriate the funds requested by the Board, the Commission did not act in an arbitrary and capricious manner, and that "lio grants accruing to the school district may ba expended for any purpose unless such expenditure has been approved by the Commission ...."25

\section{SUMMARY}

From the materials contained in this chapter it appears that a requirement is common that some state agency assume the responsibility for approving proposed building plans and specifications of local school districts contemplating construction.

1. The number of state legislatures enacting statutory provisions which provide some form of financial assistance to local school districts for the construction of school buildings is continually increasing.

2. Statutory provisions requiring state approval of school building plans and specifications are found in a considerable numiver of states. No single plan of procedure is

\section{Ibid.}


found in all of them. The state department of education is the agency most frequently stipulated to approve school building plans, but a number of states require approval by the state board of health or other state agencies. A few require approval by two or more agencies.

3. A number of states require plans and specifications for the construction or repair of local school buildings to be prepared in compliance with a set of building regulations prescribed at the state level. The state department oi education is the agency most frequently responsible for preparing regulations of this kind, although they may be prepared dealing with particular aspects of school building construction by the state board of health or other state agencies. In a few states, building regulations are prepared jointly by the state department of education and some other designated state agency.

4. In the absence of express authority granted to municipal governments, the courts are divided with respect to the issue of whether local school districts need to comply with municipal building codes while constructing school buildings. The courts have interpreted some statutes to indicate that school districts must comply with these codes, but in other states the fact that the local district must comply with state regulations has been held to preempt the power to control construction and districts have been required to comply only with the state regulations. 
5. Both state regulations and state approval of building plans and specifications may be directed toward the protection of the public interest in connection with (a) economical financial administration, (b) health, sanitation, and public safety, or (c) the eciucational service to be provided by the building. The present investigation, however, has been restricted to state action dealing primarily with the area of the financing of local school buildings.

6. The majority of states have enacted statutory provisions giving sone form of financial assistance to school districts contemplating construction. The approval of building plans and specifications is common in these states in order to qualify for state school construction aid. The agency used most frequently for the approval of building plans and specifications, in deternining a district's eligibility for state school construction aid, is the state departinent of education. 


\section{CHAPTER V}

\section{SCHOOL BONDS, SHORT-TERIN DEBTS, AND \\ THE INVESTMENT OF SURPLUS FUNDS}

The materials contained in this chapter deal with what are commonly referred to as "special school funds." These are funds authorized by statute for a specific purpose or expenditure. Special school funds may be used only for the purpose stipulated in the statutory provisions. In the absence of express statutory authority granting permission to collect and use these special funds, school districts are expected to operate on a "pay as you go" plan. Many states have enacted legislation to permit school districts the right to borrow funds either as short-terin loan obligations or as lon:-term bond obligations. This power to borrow money and create school district "indebtedness" is being used to a greater extent as increased school enrollment and increased cost of school construction make it difficult for school districts to pay for current obligations. The term "indebtedness" means "the owing of a sum of money upon a certain and express agreement." 1

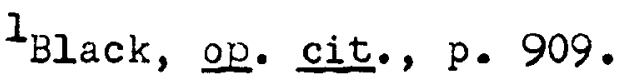


The provisions of the state statutes differ as to the method and the amount school districts may borrow. This usually is expressed in terms of a percentage of the assessed valuation of the taxable property confined within the school district boundaries.

It is the purpose of this chapter to examine the statutory provisions relating to power of school districts to borrow funds, and the procedures that must be complied with.

Davis, ${ }^{2}$ writing in The American School Board Journal, discussed the legal requirements of school districts to create indebtedness in the several states, and commented on the great variation of requirements that existed at that time. He wrote:

There is a great variation with respect to the requirements written into the laws of the different states regarding the authorization of temporary indebtedness. Thirty-one states authorize the borrowing of money and issuing therefor evidences of indebtedness other than bonds. Seventeen states have no statutory provisions for borrowing money other than through bond issues. Fourteen of these states authorize the issuing of warrants in anticipation of receipts to furnish funds to meet financial obligations. The other three states have no provisions for meeting obligations in case of shortage of funds and, therefore, it is assumed that these states operate on a "pay as you go basis." Twenty-seven of the above 31 states authorize the incurring of temporary loans for current expenses. These states together with two others, making a total of 29

2 Donald P. Davis, "Legal Requirements in School Indebtedness and Proposed Legislation," The American school Board Journal, XCVI (February, 1938), $31-3 \overline{2}$. 
states, authorize temporary loans for the payment of salaries. The money received from temporary loans may be used for permanent improvements in 24 states. Four states authorize temporary loans to provide money for building purposes in anticipation of proceeds from a bond issue.

Forty states provide for the refunding of boncis, 18 for the funding of temporary indebtedness, anci 10 for the funding of warrants.

of 25 states that provicie a single maximum term for which boncis may be used, the maximum term runs from 15 to 40 years, with a meuian of 20.9 years.

Serial bonas are required in 30 states. The general tendency in recent legislation is toward serial bonds. 3

This chapter has been broken down into four sections in order to have continuity to the materials presented herein:

1. The general body of the law pertaining to the creation of school district indebtedness and the investment of surplus funds

2. Statutory provisions and court decisions relating to school district bonds

3. Statutory provisions and court decisions relating to shortterm loan requirements

4. Statutory provisions and court decisions relating to the investment of school district surplus funds.

\section{THE GENERAL BODY OF THE LAW}

Where legislatures have enacted statutory provisions permitting school districts to incur indebtedness, strict

\section{${ }^{3}$ Ibid.}


mandatory adherence to the applicable provisions must be complied with. Corpus Juris Secundum states:

In the absence of a statute or constitutional provision providing otherwise, a school district or other local school or ganization has no authority to incur indebtedness. However, since a state legislature generally has the power to create local school organizations, it also has the power to incur indebtedness or to make expenditures, either by express provision to that effect or by implication, but the power of the legislature so to do must be exercised by it within constitutional linitations. Where the legislature has duly granted a local school organization the authority to incur indebtedness or to make expenditures, such authority should be exercised only to the extent, and in the manner, and by the board or officers, autinorized by the legislature. Expenditures should be made in good faith and pursuant to constitutional and statutory authority. 4

In discussing the amount of indebtedness that a school

district may create, the general body of the law states:

The amount of inciebtedness or expenditures which a school organization may contract ordinarily is limited by statutory or constitutional provision, and the legislature has no power to grant such a school organization the authority to exceed its constitutional debt linit, since the fact that the legislature is given constitutional authority to provide an efficient school systern will not authorize it to legislate without regard to constitutional debt limitations. However, in orcier to be invalid, a statute must, in fact, increase the indebtedness of a local school organization beyond its constitutional debt limit, and a statute which may, but does not necessarily, have such effect is not invalid. 5

The power to issue and sell boncis by school districts

479 C.J.S. Power to incur indebtedness and expenditures, par. 323 (1952).

${ }^{5}$ Ibid. Limitation of amount, par. 325. 
is also covered in paragraph 325 of Corpus Juris Secundum:

Ordinarily bonds of a local school organization are debts of such organization within the meaning of a limitation on the amount of indebtedness which may be incurred by it, but the mere voting of such bonds does not create an indebtedness to be considered in cornputing the existing indebtedness unless and until the bonds are issued and sold, or until they are issued, lithographed, approved by the proper officers, duly registered, and sold and delivered to the purchaser. 6

The power of a school district to create indebtedness by borrowing can be done only if the legislature has enacted statutory provisions authorizing the action, or the authority is expressly granted in the state constitution. The school district may create indebtedness by borrowing if the power to do so may be implied from some other authority granted to the school district, according to Corpus Juris Secundum. 7

\section{SCHOOL BONDS: LONG-TERN OBLIGATIONS}

School district bonds are issued by school officials requiring large sums of money over long periods of time for the financing of special projects. Generally, school bonds are issued and sold for contemplated school construction, although within recent years state legislatures have enacted provisions extending the purposes for which bonds may be issued to include the purchasing of needed transportation equipment.

\footnotetext{
${ }^{6}$ Ibid.

7 Ibid. Borrowing money, par. 329.
} 
The authority of a school board to issue bonds cannot be implied from the knowledge that school boards generally are responsible for the "operation and maintenance" of the school system. The power to issue bonds or long-term debt obligations must be expressly granted to the school districts of the state either by statutory provision or constitutional enactment. Most of the states have enacted statutory provisions for the issuing of school bonds. Few states have the power granted by the state constitution, and some have both.

When authority to issue negotiable bond instruments has been conferred on a school district, the procedures to be followed are set down in detail and must be complied with. The procedure includes the passing of a resolution at a legal board meeting, or by a petition or lesal voters asking for the bond issue. The passing of the appropriate legal resolution is followed by a school election, usually called a "school bond election." In a few instances, school boards may issue boncis of stipulated amount without an election, but these are in the minority.

From the tine bonds are legally authorized until they are printed, issued, and delivered to the purchaser, it is usually necessary to establish their legal validity. This includes seeing that they are printed to conform to statutory provisions, or that the proposed bond issue is within the legal linits of the school district maximum amount of 
indebtedness permitted by law.

This section of the study is concerned with the approval required by some state agency of the proposed bond issue. All 50 states have statutory provisions permitting school districts to issue long-term general obligation bonds. The purposes for which these bonds may be issued are generally linited to the repair and construction of school buildings, except, as mentioned earlier, a few legislatures have permitted the issuance of bonds for other purposes.

Table XII examines the statutory provisions requiring the approval of bond issues by state ayencies. Sixteen states require some state agency to pass on the legality of the proposed bond issue: Alabama, Alaska, Arkansas, Colorado, Delaware, Florida, Kansas, Louisiana, Miassachusetts, New Mexico, North Dakota, Rhode Island, Oregon, South Carolina, Texas, and west Virginia. The other 34 states do not require state agency approval of proposed local school district bond issues outside of the statutory provisions discussed earlier. Compliance with statutory provisions in all. states is mandatory on the school districts.

Of the 16 states requiring state a fency approval, three (South Carolina, Texas, West Virginia) must subinit the proposed bond issue to the state attorney general for his approval on the legality of the proposed issue. The state educational authorities approve proposed bond issues in Alabama, Arkansas, Delaware, Florida, Louisiana, and New Hexico. In 


\section{TABLE XII}

STATUTORY PROVISIOINS OF STATES REQUIRING STATE AGENCY APPROVAL OF LONG-TERM BONDS

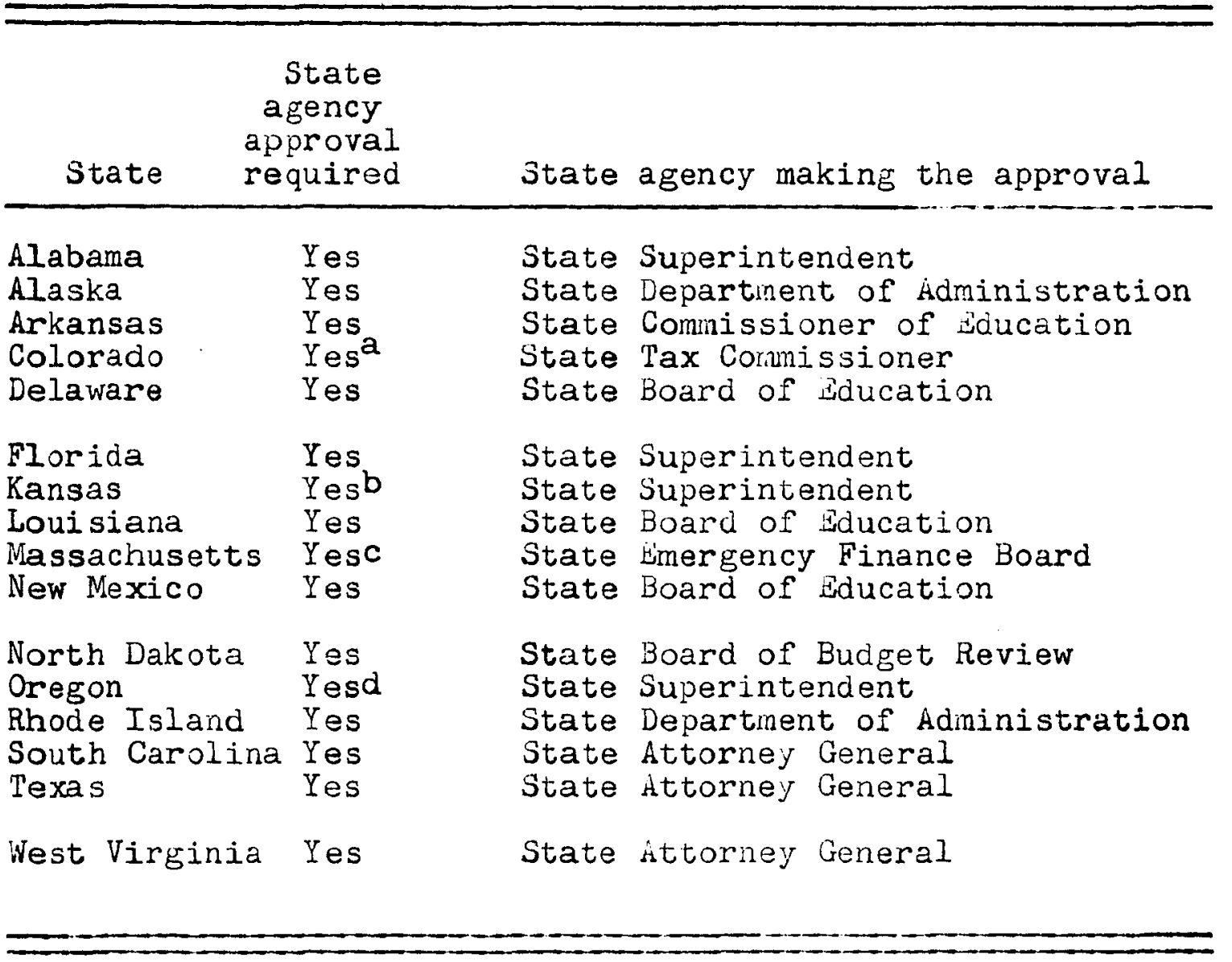

${ }^{a}$ Approval required only in case of emergency. on bonds.

${ }^{b}$ Approval required to secure a higher interest rate

CApproval require? to exceed rate of indebtedness.

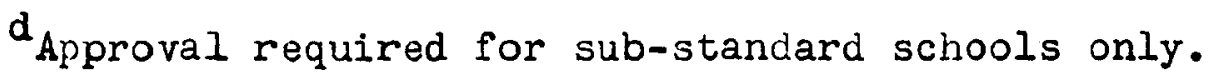


Rhode Island, and Alaska the State Department of Administration has this responsibility.

The Coloracio State Tax Comnissioner approves bonds only in cases of emergency. The State Superintendent approves bond issues in Kansas only if the school district proposes to exceed the statutory interest rate limit on the proposed bonas.

In Wassachusetts the state Emergency Finance Board approves proposed bond issues if the school district plans to exceed its legal limit of district indebtedness. Substandard schools of Oregon must submit their bond issues to the chief state school officer for his apuroval. The State Board of Budget Review perforals the responsibility of approving bond issues in North Dakota.

Table XIII examines statutory provisions for bond requirenents in regard to: maximum interest peraissible, maximum tine in years that boncis may run, and the naximum amount of incebtedness permitted in per cent of the assessed valuation. In sone states, statutory provisions have been written for the exclusion of certain districts, depending on the class and size of the district. These instances have been footnoted. The limits listed in the table are the maximum perinitted for any district in that state. For means of comparing the several states with regard to statutory provisions, these naximum linits were used even though they may not apply to all districts. The states of Alabana, California, 
Michigan, New Jersey, New York, North Carolina, Pennsylvania, Rhode Island, South Carolina, and Wisconsin vary the maximum per cent of indebtedness permitted according to the class or size of school district. Illinois, Indiana, South Carolina, and Texas have varied naximum interest rates permitted on bonds, again depending on the class or size of school district under consideration.

Arkansas perinits school district indebtedness up to a maximum of 18 per cent of the assessed valuation, with the approval of the state Board of iducation. 'Colorado permits the rate of indebtedness to go to 15 per cent of the assessed valuation in case of emergency. Emergency cases must be approved by the state Tax Commissioner in this instance. With the approval of the State Superintendent of Public Instruction, Kansas perinits interest rates to a maximum of six per cent, or the maximun interest rate without his approval is five per cent. The maximum amount of indebtedness permitted in the state of Waryland is left to a vote of the people of the district. This is the only state which has such a requirement.

Table XIV presents the sarne information as Table XIII in summary form. The maximum interest rate permitted on school bonds varies from $31 / 2$ per cent in Ninnesota to 8 per cent in Colorado. The most frequently used maximum interest rate stipulated in the statutes is 6 per cent. This is found in 35 state statutory provisions. Eleven states 
TABLE XIII

STATUTORY PROVISIUNS GOVERNING GENERAL OBLIGATION BOND CONDITIONS ${ }^{2}$

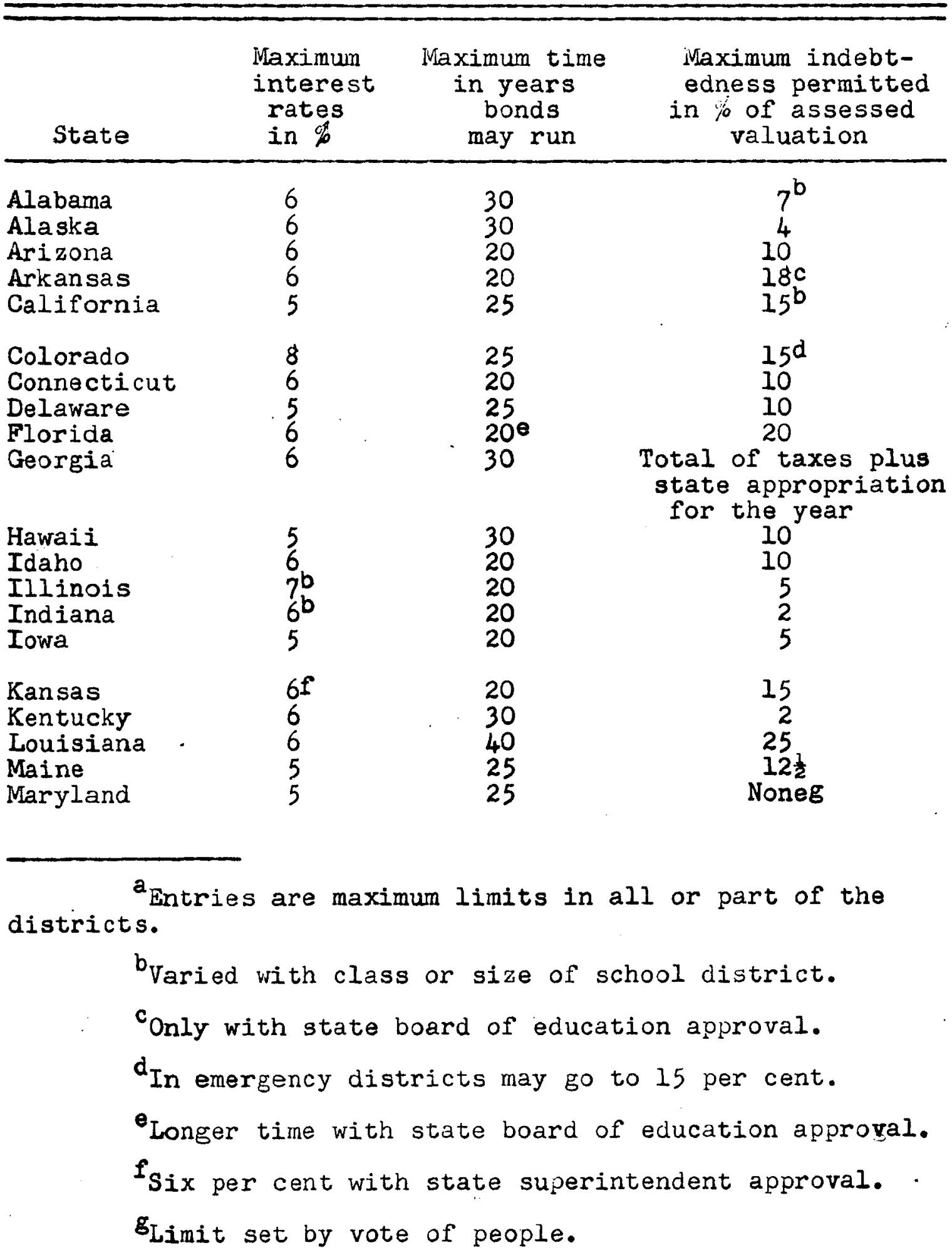


TABLE XIII (cont.)

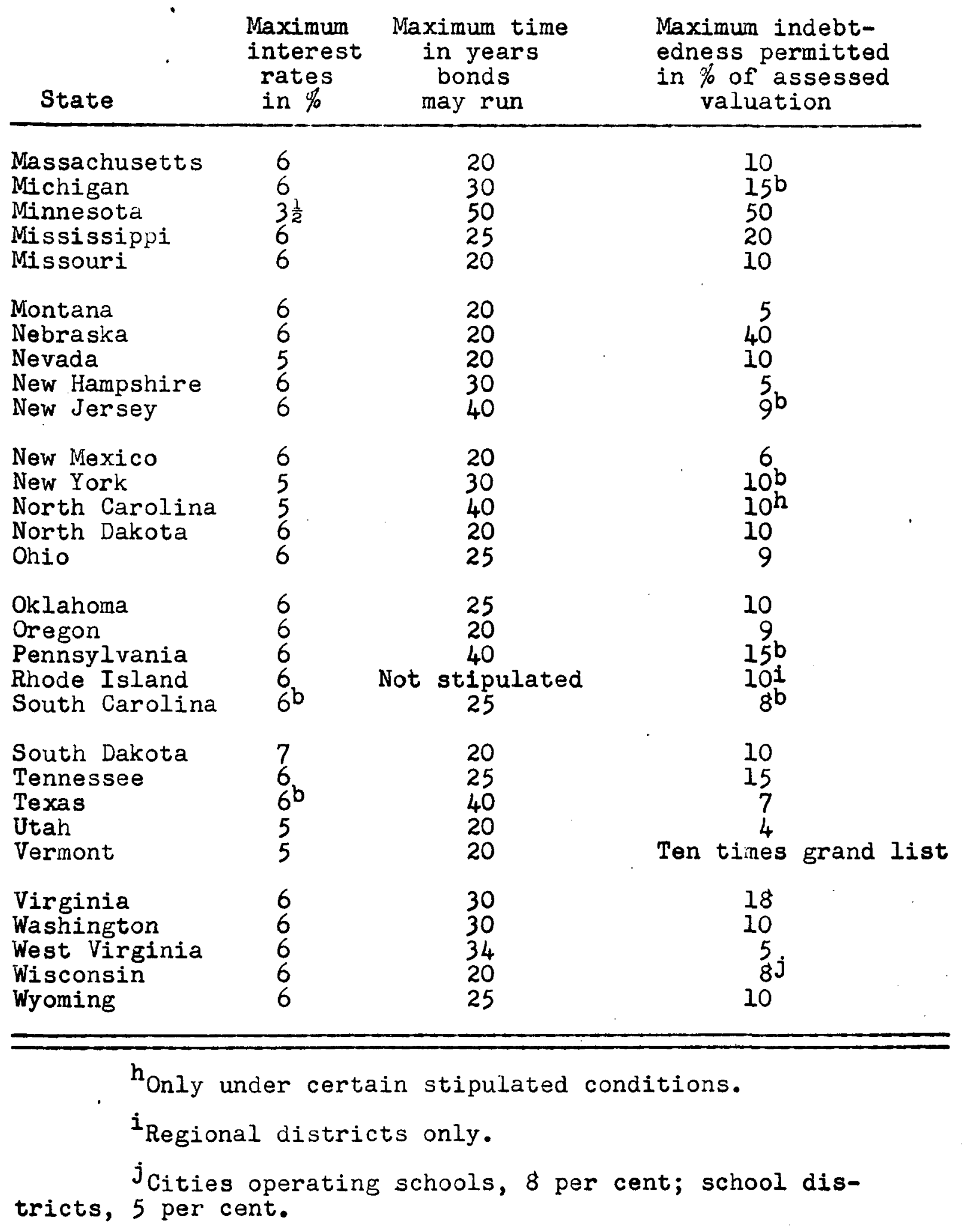


TABLI XIV

SUIMMARY OF STATUTORY PROVISIONS

GOVERNING SCHOOL DISTRICT BONDS

No. of

States

Maximum interest rate on bonds of $6 \%$ in all or part of the districts

Maximum interest rate on bonds of $5 \%$ in all or part of the districts

11

Other maximum interest rates on bonds in all or part of the districts

Maximum time bonds may run in all or part of the districts - 20 years

21

Maximum time bonds may run in all or part of the districts -25 years

11

Maximum time bonds may run in all or part of the districts - 30 years

10

Maximum time bonds may run in all or part of the districts - other than 20, 25, or 30

Limit of indebtedness in all or part of the districts - $10 \%$ of assessed valuation

Limit of indebtedness in all or part of the districts - under 10\% of assessed valuation

Limit of indebtedness in all or part of the districts - over $10 \%$ of assessed valuation

14

Other limitation regulations on indebtedness in all or part of the districts 
use 5 per cent as the maximum interest rate permitted.

The maximum time in years that school district bonds may run varies from 20 years (also the ti.ne most frequently specified) to 50 years in Minnesota. Twenty-one states specify 20 yaars in their statutory provisions; 11 states specify 25 years, and 10 states specify 30 years.

The maximuin amount of inciebteciness perinitted, in per cent of assessed valuation, varies fron the statute in haryland which sets the maximum anount by a vote of the people, discussed earlier, to a 2 per cent linit in Indiana and ientucky. The provisions of jernont indicate the linit to be expressed as ten times the grand assessnent list, while in Georgia it is expressed as the total of the taxes to de collected plus the state apportionment for the current year. All other states express the maxinum amount of inclebtedness permitted in per cent of the assessed valuation. Ten per cent is the figure used nost frequentiy. A lo per cent limitation is used for all or part of the school districts in 16 states; 17 states have limitations uncier 10 per cent, and 14 states have linitations above 10 per cent.

Applicable Court Decisions

Proposed bond issues in the state of 'Texas must meet the approval of the State Attorney General before they are offered for sale. jeveral cases have arisen in the courts of that state where this aproval has been in question. 
In the case of Love v. Rockwall Independent School District, ${ }^{8}$ the validity of the bonds was attacked because they were not approved by the Attorney General. The school board in question contemplated and were ready to submit the issue for approval when the suit was filed. The bonds were held valid, the court ruling:

The approval of independent school district bonds by the Attorney General is not a condition precedent to their issuance or the levy and collection of a tax for their payment, but need only be obtained when they are offered for sale. 9

Several years later, in Henrietta Inciependent School District v. Garrett \& Co., 10 the school board made a contract with Garrett and Company for the purchase of $\$ 60,000.00$ worth of boncls that were legally voted. The school board sold the bonds to a different party after the contract with Garrett and Company was made. The boncis were not approved by the State Attorney General, the State Board of Eaucation had not waived their right to purchase, and the State Comptroller had not registered thein before the contract with Garrett and Company was made. The school board claimed they had the right to sell the bonds to another party, and the contract with Garrett and Company was illegal since the

\footnotetext{
${ }^{8}$ Love v. Rockwall Independent School District, 238 S.W. 642 (1922).

Ibid.

10 Henrietta Independent School District v. Garrett and Company, 119 T. 14l, 25 S.W. 2nd 317 (1930).
} 
above-mentioned statutory provisions were not complied with. Garrett and Company brought this action to compel the school district to honor the original contract, and their action was successful. The court used the following reasoning:

It is the evident purpose and intent of the law to provide for the approval of all bonds and bond records by the attorney general, their registration by the comptroller, and the opportunity to purchase by the state board, before they are actually anci finally sold and delivered to an outside purchaser. A contract that contemplates all this shall be done before it is finally consummated is a substantial compliance with the law, and all that is required. Such a contract is legal and binding, and does not violate any statutory provision. II

In the state of Kentucky the local boards of education must ask the Fiscal Court to issue bonc's after the necessary legal election has been held in the district. Several cases have come before the Kentucky courts where the issuing of bonds by the Fiscal Court is mandatory after the necessary election and other statutory provisions are complied with. 12 The language in Fyfe et al. v. Hardin County Board of iducation $^{13}$ is typical of the position of the courts in relation to this mandatory issuing of bonds:

\section{${ }^{11_{\text {Ibid. }}}$.}

12 Stokely et al. v. Fleming County Board of Education, etc., $305 \mathrm{Ky} .602,205$ S.W. 2nd 168 (1947); City of Paducah v. Board of Education of Paducah, $289 \mathrm{Ky} .284,158 \mathrm{~S} . \mathrm{W}$. 2nd 615 (1942); Fiscal Court of Logal County v. Board of Education of Logan County, $138 \mathrm{Ky} .98,127$ S.W. 527 (1910)'.

13 Fyfe et al. v. Hardin County Board of iducation, $305 \mathrm{Ky} .589,205$ S.W. 2nd 165 (1947). 
The court has uniformly held that the discretion as to the amount of money necessary for the proper operation of the school system is vested in the board of education and not in the tax levying authority, and the latter has been mandatorily required to levy a tax for school purposes sufficient to produce the amount requested by the board of education. The tax levying authority can question the amount requested only if the budget expenditures, a computation unlawfully arrived at, or bad faith on the part of the school board appears 4

Cases have come before the courts where the language used by the board of education in passing its resolution for a proposed bond issue or the language of the printed ballots did not comply with the exact words printed in the statutes. School boncis were held invalid in Kentucky where the statutes read that the governing board shall "fix the time bonds shall run, and, if a serial issue, the amount to mature at each time. "15 The resolution passed by the board of education in the instant case stated only the "issuance of bonds in the amount of $\$ 1000.00$ each and the same to mature in not exceeding forty years." The exact letter of the law was not complied with, anc the boncs were not valid. In a Texas case ${ }^{16}$ the election of a proposed bond issue was challenged on the basis that the ballots used read

\section{Ibid.}

${ }^{15}$ Suratt et al. v. Board of Education of City of Ashland, $313 \mathrm{Ky} .343,231 \mathrm{~S} . W$. 2nd 88 (1950). See also Howard v. Board of Education of Harlan Independent School District, $311 \mathrm{Ky} .130,223 \mathrm{s.W}$. 2nd 721 (1949).

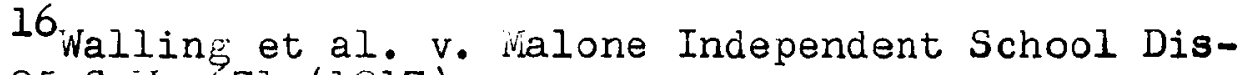
trict, 195 S.W. 671 (1917). 
"For the Bonds" and "Against the Bonds" instead of "For the Tax" and "Against the Tax" as worded in the Texas statutes. The court ruled that the bonds were valid since the statute was complied with substantially even though the exact words were not used.

If the applicable state statutes indicate a minimum tirne bonds must be held, bonds issueci to mature at a time less than the specified time are invalid. The case in question issued bonds that matured three days short of the mandatory ten-year period. 17

If a bond election is not successful, a board of education may hold as many elections as it may deem proper within a given year, in the absence of express statutory provisions prohibiting such actions. So ruled the Court of Appeals of Kentucky. ${ }^{18}$

In Arizona the question arose on the interpretation of bonded inciebtedness allowed school districts. Under the school code, school districts are permitted inciebtedness up to 4 per cent of the assessed valuation. In another statute, political subaivisions are permitted to incur indebtedness up to 6 per cent of the assessed valuation. The question arose whether school districts may incur indebtedness up to

17 Peoples Bank of St. Paul v. School District No. 52, 3 N.D. 496, 57 N.W. 787 (1893). See al so Norton v. Town of Dyersburg, 127 U.S. 160, 8 Sup. Ct. 111 ( 1888 ).

18 McKinney $v$. Board of Trustees of the Cadiz Graded Common School District, $144 \mathrm{Ky} .85,137$ S.W. 839 (1911). 
10 per cent of the assessed valuation, the sum of the two statutory provisions. The court ruled as follows in Armer et al. v. wade et al. $:^{19}$

So we conclude that construing the constitutional provision and section 2647 together, school districts are authorized and empowered to incur indebtedness up to, but not exceeding, 10 per centum of the value of their taxable property as ascertained at the last previous assassment for the state and county purposes, unless there is sone other provision of law that compells a different construction. 2

The New York statutes provide that in order to issue bonds over 10 per cent of the assessed valuation, a twothirds majority vote is required. The question recently arose as to whether bonds were vaiid where the required tivothirds vote was not secured at the election. At the tine of the election the proposed bonus would exceed the 10 per cent limit, but when the bonds would actually ve sold the district would have increased valuation and be uncier the 10 per cent linit. The court ruleu tnat tine bonds are legal on the grounds that "the only bar against the issuance of bonds by a school district would be its debt condition at the tine boncis are to be issued. ${ }^{21}$

${ }^{19}$ Arner et al. v. Wade et al., 48 Ariz. 1, 58 P. 2nd $525(1936)$.

\section{Ibid.}

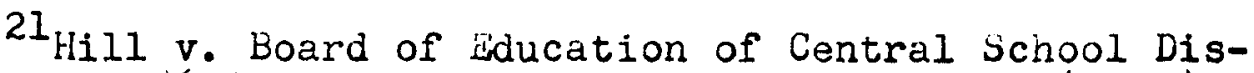
trict No. 2, 286 App. Div. 332, 143 N.Y.S. 2nd 415 (1955). See also Rigaird v. Board of Education of Central School District vo. 2, 207 Misc. 742, 142 N.Y.S. 2nd 168 (1955). 
The Kentucky statutes limit school districts to a 2 per cent limit of the assessed valuation, unless an emergency exists. The energency, as stated in the statutes, requires that the public health or safety be endangered. The burning of a school building 22 and the condemnation of a building as being unsafe $e^{23}$ by a state inspector of school buildings were not regarded as energency conditions when the school districts sought to replace school facilities by exceeding the 2 per cent linit and invoking the emergency clause. The court ruled that "Before this exception can be invoked, it must plainly appear that the additional expenditure is required for the public health and safety." 24

\section{SHORT-TERI LOHNS}

School districts find it necessary to borrow funds for short periods of time when the funds on hand are not sufficient to execute the current operating budget or the district is faced with an emergency of one kind or another. Emergencies are generally created by the failure of the school district to collect anticipated taxes or other revenue. imergencies also can be created by the desire to implement a phase of the educational program deemed imnediately necessary

22 Nelson $v$. Board of Education of Williansburg, $213 \mathrm{Ky}$. 714,281 S.W. 808 (1926).

23 Buckner v. Board of Education of Owensboro City School District, $236 \mathrm{Ky} .768,34$ S.W. 2nd 236 (1930). 
and not budgeted for, or some major disaster such as fire, flood, or a terrific increase in school expenditures due to rising enrollments or other unforeseen acts.

In order for a school district to have the authority to borrow funds, the authority has to be expressly granted by the legislature or by constitutional enactment. In some instances, in the absence of express granted authority, authority may be implied to borrow funds from some other statutory provision.

McCann 25 states that short-tern loans are generally of three types:

School District Registered Warrants-- If money is not available in the fund to pay the warrant when it is presented for payment, the statutes may permit it to be "registered" and paid later when money becomes available in the fund .... W en registered, warrants becóme in effect short-term debt obligations of the school district. Warrants may ciraw interest at a statutory rate, at a contract rate negotiated by the school board, or may draw no interest at all as provided by statute.26

Tax Anticipation Varrants-- Tax anticipation warrants are orders upon the district treasurer to pay warrants out of particular tax funds if and when these are collected .... Unlike registered warrants, tax anticipation warrants do not ordinarily have priority with respect to payment. Each warrant is due to be paid when presented and/or when funds become available to pay it.27

Short Term Loans-- As a third means of raising money for short periods, school districts in some states are authorized to borrow money on their promissory notes....

25 Lloyd W. McCann, "The Management of the School Debt," Chapter $V$ of Law and the School Business Manager, edited by Lee 0 . Garber (Danvilie: Interstate Printers and Publishers Company, 1957), pp. 109-141.

26 Ibid., p. 117 . 27 Ibid., p. 119. 
Short-terin loans are subject to the usual restrictions upon other forins of temporary debt obligations. The loans are refarded as debt and are subject to debtlimitation laws. Interest rates, the length of loan periods, and the purvoses for which the loans are made must all be within the powers granted by statute.28

1939,29 sumnarized the statutory provisions regarding shortterin borrowing of school districts as they existed at that time:

Forty-four of the 40 states have set up regulations governing short teria borrowing by school districts. The statutes generally specify (I) the amount of borrowing that may be done, (2) the funds against which borrowing may be done, (3) the maxinum interest rate that may be paid, (4) the group or individual authorized to negotiate the transaction. 30

In discussing the actual statutory provisions in ef-

fect at that tine, iggert cominents in the same article:

Great variation is evident in the freedon given to the school boards in negotiating loans. The provisions of the statutes of sone states are given in great detail, while others briefly authorize the boards to borrow money without any restrictions on the manner of sale, bidding, advertising, and other contingent factors. It is evident from the statutes that the school boards generally have the power to negotiate short term loans without securing any additional consent from the people as is usually necessary when issuing long term bonds. 31

Table XV examines the statutory provisions governing

$2{ }^{8}$ Ibid. , p. 121.

29 Walter A. Üggert, "Short Tern Borrowing for jchool Purposes," The American jchool Board Journal, XCIX (December, 1939).

30 Ibid., p. 40. ${ }^{31}$ Ibid., p. 45. 
short-term loan procedures in the states that zequire some state agency approval. If state agency approval is required for the issuance of short-term loans, it applies to all three of the types defined earlier.

The data presented in this table are in agreement with the information just presented by Eggert. The data collected indicate no single pattern of procedures required by the states in issuing short-term loan obligations.

Forty-eight of the 50 states have statutory provisions permitting school districts to borrow funds for short periods. Alaska and Delaware are the only two that do not have statutory or constitutional provisions permitting school districts to negotiate short-term loans.

Twelve of the 48 states permitting short-term obligations require some form of state agency approval. These 12 are: Alabama, Arkansas, Florida, Hawaii, Iowa, Louisiana, Michigan, Wississippi, Nevada, New Miexico, Pennsylvania, and South Carolina. Of these states Alabama, Arkansas, Florida, Hawaii, anci ivichigan require approval by the state educational authorities. Iowa, iMississippi, Nevada, New Mexico, and South Carolina require the approval of the State Finance Department; Louisiana requires the approval of the State Tax and Bond Board, while Pennsylvania has placed the responsibility for approval of loans with the State Department of Internal Affairs.

Five states require local agency approval for 


\section{TABLE XV}

STATUTORY PROVISIONS GOVERNING SHORT-TERM LOAN PROCEDURES

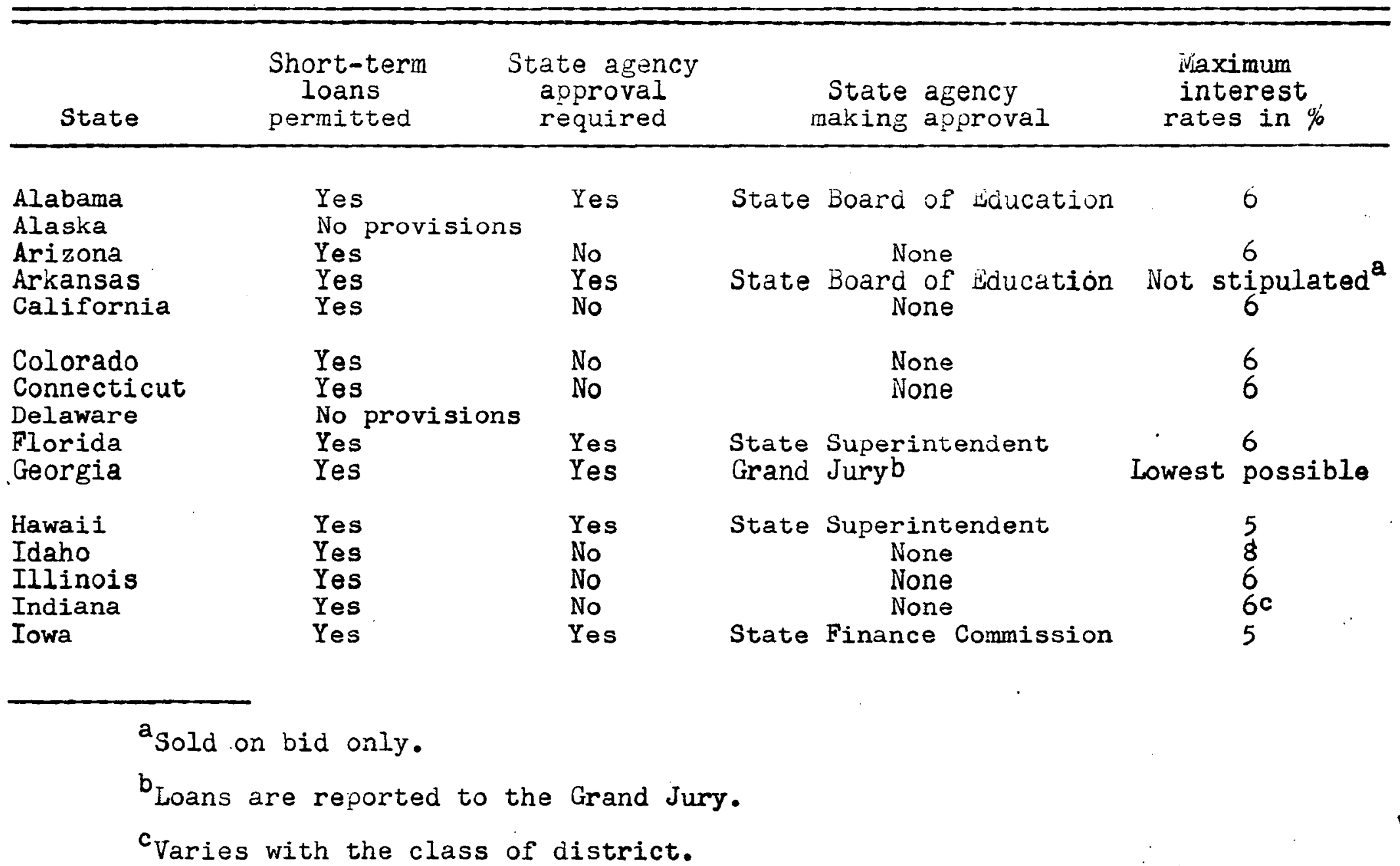


TABLE XV (cont.)

\begin{tabular}{|c|c|c|c|c|}
\hline State & $\begin{array}{l}\text { Short-term } \\
\text { loans } \\
\text { permitted }\end{array}$ & $\begin{array}{l}\text { State Agency } \\
\text { approval } \\
\text { required }\end{array}$ & $\begin{array}{l}\text { State agency } \\
\text { making approval }\end{array}$ & $\begin{array}{l}\text { Maximum } \\
\text { interest } \\
\text { rates in \% }\end{array}$ \\
\hline $\begin{array}{l}\text { Kansas } \\
\text { Kentucky } \\
\text { Louisiana } \\
\text { Maine } \\
\text { Maryland }\end{array}$ & $\begin{array}{l}\text { Yes } \\
\text { Yes } \\
\text { Yes } \\
\text { Yes } \\
\text { Yes }\end{array}$ & $\begin{array}{l}\text { No } \\
\text { No } \\
\text { Yes } \\
\text { No } \\
\text { No }\end{array}$ & $\begin{array}{l}\text { None } \\
\text { None } \\
\text { State Bond and Tax Board } \\
\text { None } \\
\text { None }\end{array}$ & $\begin{array}{l}6 \\
6 \\
6 \\
5 \\
5\end{array}$ \\
\hline $\begin{array}{l}\text { Massachusetts } \\
\text { Michigan } \\
\text { Minnesota } \\
\text { Mississippi } \\
\text { Missouri }\end{array}$ & $\begin{array}{l}\text { Yes } \\
\text { Yes } \\
\text { Yes } \\
\text { Yes } \\
\text { Yes }\end{array}$ & $\begin{array}{l}\text { No } \\
\text { Yes } \\
\text { No } \\
\text { Yes } \\
\text { No }\end{array}$ & $\begin{array}{l}2 / 3 \text { vote of people } \\
\text { State Superintendent } \\
\text { None } \\
\text { State Finance Commissione } \\
\text { None }\end{array}$ & $\begin{array}{l}\text { Not stipulated } \\
4 \mathrm{~d} \\
6 \\
6 \\
4 \mathrm{f}\end{array}$ \\
\hline $\begin{array}{l}\text { Montana } \\
\text { Nebraska } \\
\text { Nevada } \\
\text { New Hampshire } \\
\text { New Jersey }\end{array}$ & $\begin{array}{l}\text { Yes } \\
\text { Yes } \\
\text { Yes } \\
\text { Yes } \\
\text { Yes }\end{array}$ & $\begin{array}{l}\text { No } \\
\text { No } \\
\text { Yes } \\
\text { No } \\
\text { No }\end{array}$ & $\begin{array}{c}\text { None } \\
\text { None } \\
\text { State Finance Board } \\
\text { None } \\
\text { None }\end{array}$ & $\begin{array}{c}6 \mathrm{~g} \\
6 \mathrm{c} \\
8 \\
\text { Not stipulated } \\
6\end{array}$ \\
\hline New Mexico & Yes & Yes & $\begin{array}{l}\text { State Public jchool } \\
\text { Finance Division }\end{array}$ & $\begin{array}{c}6 \text { (effec- } \\
\text { tive } 7 / 1 / 62)\end{array}$ \\
\hline
\end{tabular}

$d_{\text {Special legislation for certain districts. }}$

For building loans.

$f_{\text {Special legislation for certain districts. }}$

gaximum rate on certain type loans only. 
TABLE XV (cont.)

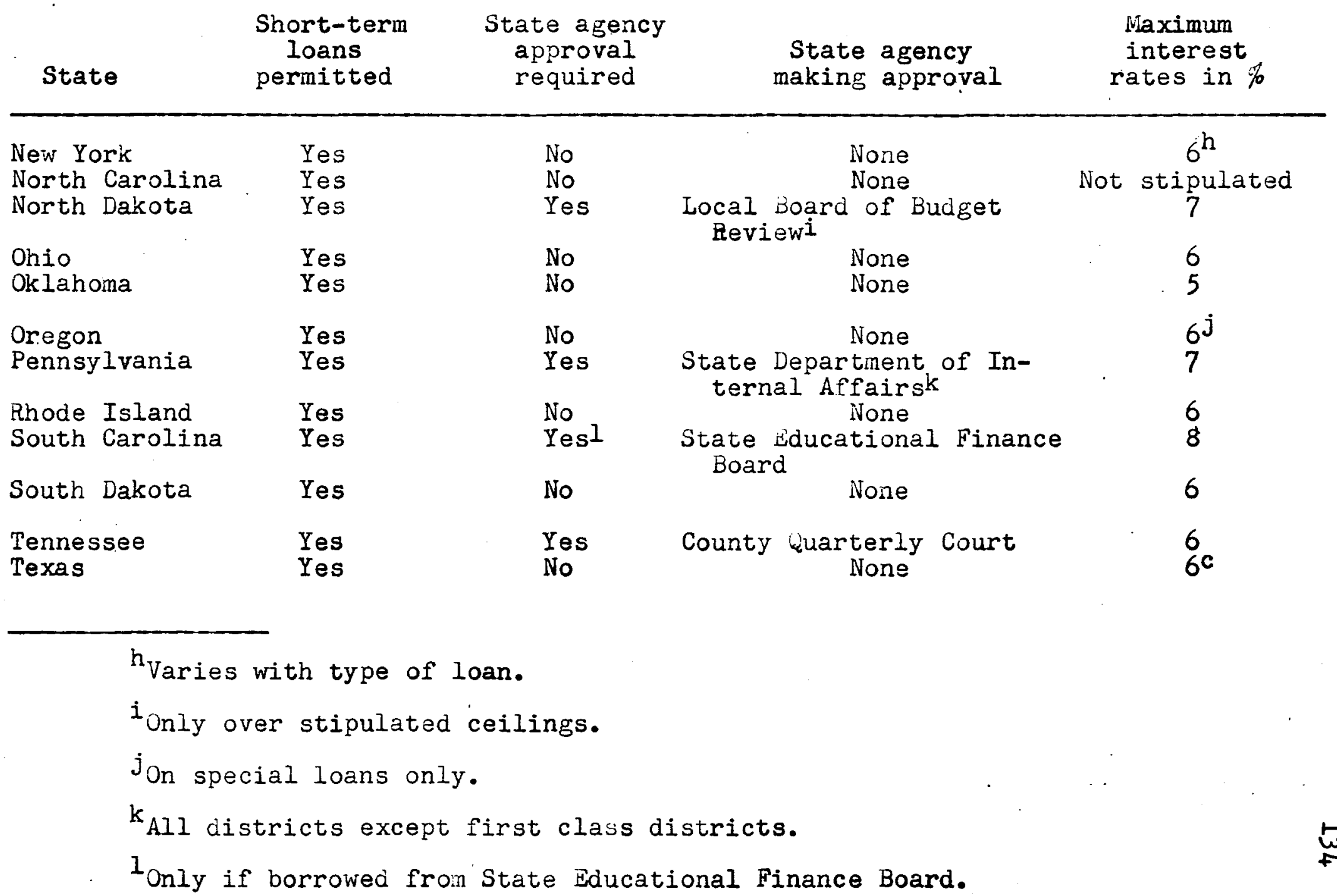


TABLE XV (cont.)

\begin{tabular}{lcccc} 
State & $\begin{array}{c}\text { Short-term } \\
\text { loans } \\
\text { permitted }\end{array}$ & $\begin{array}{c}\text { State agency } \\
\text { approval } \\
\text { required }\end{array}$ & $\begin{array}{c}\text { State agency } \\
\text { making approval }\end{array}$ & $\begin{array}{c}\text { Maximum } \\
\text { interest } \\
\text { rates in } \%\end{array}$ \\
\hline $\begin{array}{l}\text { Utah } \\
\text { Vermont }\end{array}$ & Yes & No & None & Not stipulated \\
Virginia & Yes & No & None & Not stipulated \\
Washington & Yes & No & None & 6 \\
West Virginia & Yes & Yes & Local sheriff endorses & Not stipulated \\
Wisconsin & Yes & No & None & $6^{\text {h }}$ \\
Wyoming & Yes & No & None & 6 \\
\end{tabular}


negotiating short-term loans. Georgia school districts require the approval of the county grand jury; Massachusetts requires a two-thirds majority vote of the people at an annual meeting; North Dakota requires the approval of the local Board of Budget Keview; Tennessee requires the approval of the County warterly Court, and in West Virginia the local sheriff must endorse short-term loans for school districts. The other states permitting short-tern loans require a resolution by the governing board only. No other agency approval is necessary.

Twenty-eight states have a maximum interest rate of 6 per cent on short-term loans. As of July 1, 1962, New Mexico's maximum interest rate on short-tern loans drops from 8 per cent to 6 per cent. 32

The statutory provisions on maximum interest rates in Georgia state, "At the lowest jossible rate." In Arkansas, Massachusetts, New Hampshire, North Carolina, Utah, Vermont, and West Virginia the maximum interest rate permitted is not stipulated. iNevada, Idaho, and South Carolina have the highest pernitted interest rate of all states, 8 per cent. viichigan and $\mathrm{K}$ issouri have the lowest maximum interest rate permitted in all states, 4 per cent.

Table XVI examines the statutory provisions governing p. 13 .

32 Twenty-fifth Legislature, Bill No. 15, op. cit., 
the type of short-term loans permitted and the uses for which these loans may be made. The statutory provisions governing the type of loans permitted have been interpreted in the terins proposed earlier by vic Cann. 33 The abbreviations in Table XVI under "Type of loans pernitted" stand for the following: 'LAW, tax anticipution warrants; PN, promissory notes; Rit, registered warrants. Loans were classified as tax anticipation warrants (1) if they were specified as such in the statutes, or (2) if proceeds from specific tax levies were pledged for their repayment. The distinction between various obligations such as these is sometimes shadowy and, in the absence of court decisions covering the specific points, a somewhat different classification of loans might be made for other purposes.

Alaska and Delaware are missing froin the list of states presented in Table XVI. At the present time they do not have statutory provisions permitting short-term borrowing. Several states permit the use of more than one type of loan. No one pattern of the type anci amount of loans that may be made or of the procedures to be followed exists among the several states.

The most conmon language used to describe the purposes for which short-term loans may be made is: "general

\section{$33_{\text {IIC Cann, 10c. cit. }}$}


TABLE XVI

STATUTORY PROVISIONS GOVERNING THE TYPE

AND USE OF SHORT-TERM LOANS

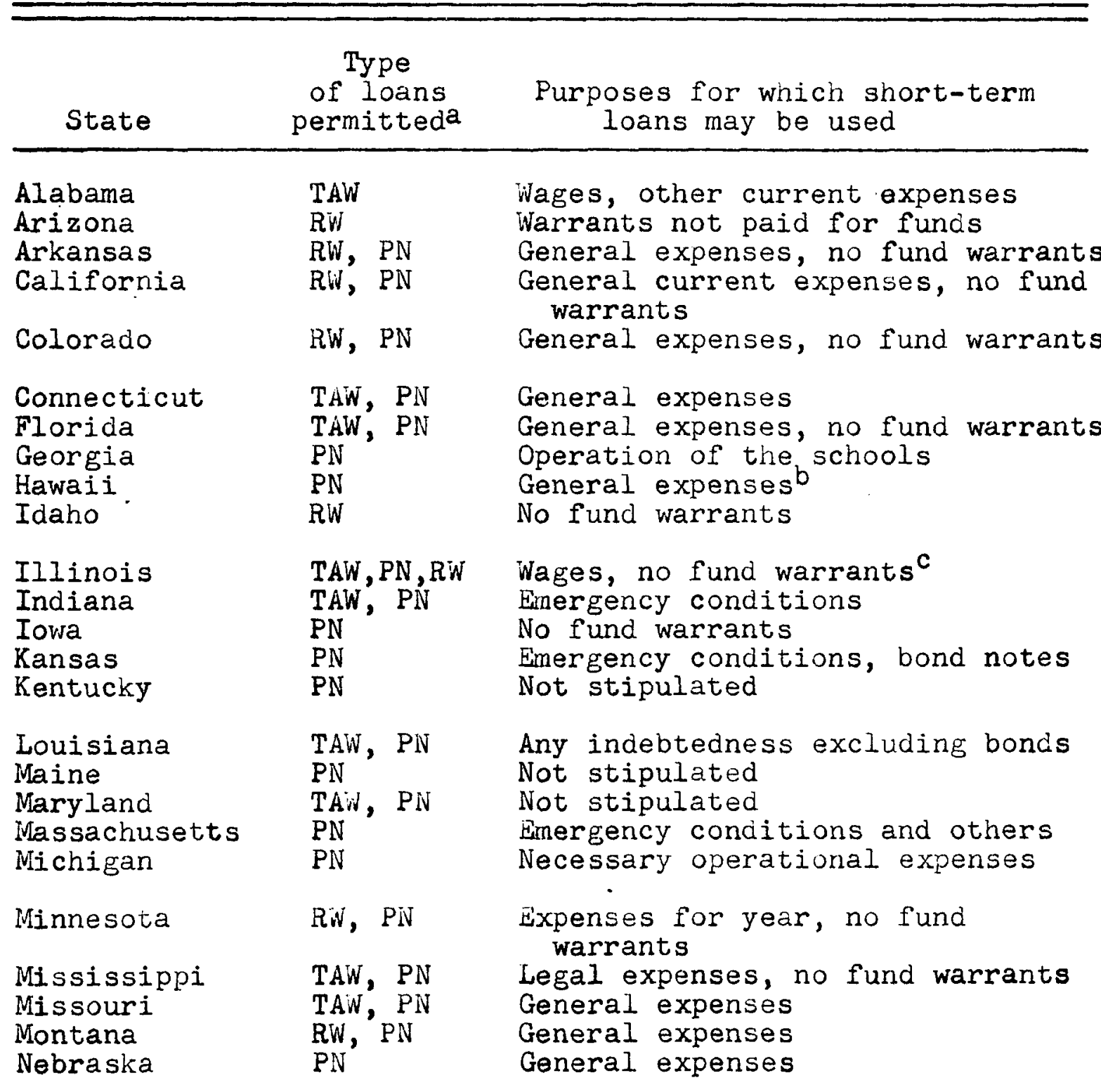

a TAW stands for Tax Anticipation Warrants; RW, Registered Warrants; PN, Promissory Note.

${ }^{b}$ Counties loan funds to districts.

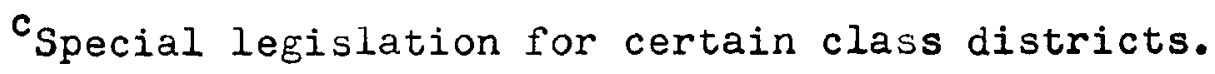


TABLE XVI (cont.)

\begin{tabular}{|c|c|c|}
\hline State & $\begin{array}{l}\text { Type } \\
\text { of loans } \\
\text { permitted }\end{array}$ & $\begin{array}{l}\text { Purposes for which short-term } \\
\text { loans may be used }\end{array}$ \\
\hline $\begin{array}{l}\text { Nevada } \\
\text { New Hampsinire } \\
\text { New Jersey } \\
\text { New Mexico } \\
\text { INew York }\end{array}$ & $\begin{array}{l}\text { PN } \\
\text { TAW, PN } \\
\text { TAW, RW, PN } \\
\text { TAW, PN } \\
\text { TAW, RW, PN }\end{array}$ & $\begin{array}{l}\text { Emergency conditions } \\
\text { Any school purpose } \\
\text { General expenses } \\
\text { General expenses } \\
\text { Loans for a variety of purposes }\end{array}$ \\
\hline $\begin{array}{l}\text { North Carolina } \\
\text { North Dakota } \\
\text { Uhio } \\
\text { Oklahoma } \\
\text { Oregon }\end{array}$ & $\begin{array}{l}\text { PN } \\
\text { RN, PN } \\
\text { RW, PN } \\
\text { RN, PN } \\
\text { RiN, PN }\end{array}$ & $\begin{array}{l}\text { Current school expenses } \\
\text { Current school expenses } \\
\text { General expenses } \\
\text { No fund warrants } \\
\text { General expenses, no fund warrants }\end{array}$ \\
\hline $\begin{array}{l}\text { Pernsylvania } \\
\text { Rhode Island } \\
\text { South Carolina } \\
\text { South Dakota } \\
\text { Tennessee }\end{array}$ & $\begin{array}{l}\text { PN } \\
\text { PN } \\
\text { PN } \\
\text { PN } \\
\text { PN }\end{array}$ & $\begin{array}{l}\text { General expenses, no fund warrants } \\
\text { General expenses } \\
\text { General claims } \\
\text { General expenses, no fund warrants } \\
\text { Wages, operating expenses, } \\
\text { capital outlay }\end{array}$ \\
\hline $\begin{array}{l}\text { Texas } \\
\text { Utah } \\
\text { Vermont } \\
\text { Virginia } \\
\text { Washinton }\end{array}$ & $\begin{array}{l}\text { PN } \\
\text { PN } \\
\text { TAW, PN } \\
\text { PN } \\
\text { RW }\end{array}$ & $\begin{array}{l}\text { Salaries and seneral expenses } \\
\text { General maintenance } \\
\text { General expenses } \\
\text { General expenses } \\
\text { Emerency conditions }\end{array}$ \\
\hline $\begin{array}{l}\text { West Virginia } \\
\text { Wisconsin } \\
\text { Wyoming }\end{array}$ & $\begin{array}{l}\text { RW, PN } \\
\text { TAW, PN } \\
\text { RW, PN }\end{array}$ & $\begin{array}{l}\text { Not stipulated } \\
\text { General expenses } \\
\text { General expenses, no fund warrants }\end{array}$ \\
\hline
\end{tabular}


school expenses," "general school purposes," and "warrants not paid for want of funds." Kentucky, Waine, ivaryland, and West Virginia permit the use of short-term loans but do not indicate the purposes for which they may be used. Inciana, Kansas, Viassachusetts, Nevada, and Washington expressly say that short-term loans shall be used "for emergency conditions" only.

Applicable Court Decisions

Only one case could be located where the power to borrow money was an implied power from other legislation. The case occurred in Florida 34 where the State Constitution provided for the issuance of bonds by special taxing districts under certain specified restrictions. The court indicated that since there were no express provisions against the borrowing of funds, loans coulc be made by virtue of an implied power. Florida has statutory provisions permitting school districts to borrow funds on short-tern loans.

In the state of South Carolina the trustees of Barnweil County ${ }^{35}$ interpreted the following statutory provision as giving them the authority to borrow money for the construction of a school building:

It shall be unlawful for the trustees of any school

${ }^{34}$ Logan v. Board of Public Instruction of Polk County, 118 Fla. 184, 158 So. 720 (1935). 2nd $52(1948)$.

35 Craig et al. v. Bell et al., 211 S.C. 473,46 S.E. 
district in Barnwell County to borrow money for any purpose or create any indebtedness for and in behalf of their school district unless such loan or indebtedness has been first approved by the County Board of Education, the Treasurer of Barnwell County and the County Auditor. 36

The South Carolina supreme Court said that this provision was not an authorization to borrow noney. They reasoned:

Clearly this act of the Legislature does not expressly authorize the borrowing of money, and in my opinion authority to borrow is not reasonably implied from it. The statute is rather a limitation upon the borrowing of money, than an authorization.37

South Carolina is one of the states that have special legislation pertaining to individual school districts. The loans above were declared invalid.

In Kentucky, where certain school buildings were titled to a holdin: corporation, the county board of education coula not borrow money to help the holding corporation finance a building that was destroyed by fire. 38 The borrowing of funcs was not considered a legal debt of the county board of education.

The Supreme Court of Wisconsin ruled that loans made over the 5 per cent constitutional debt limit were invalid. 39 The school district in question received $\$ 23,000.00$ from the

$$
{ }^{36} \text { Ibid. } \quad 37 \text { Ibid. }
$$

38 Smith v. Board of Education of Pendleton County School District, $293 \mathrm{Ky} \cdot 536,169 \mathrm{~s}$. W. 2nd 600 (1943).

$39_{\text {Walker }} \mathrm{v}$. Joint school District No. 5, Town of Alma and four other cases, 255 Wis. 475, 39 N.W. 2nd 389 (1949). 
state trust fund for the erection of a new school building. At an annual meeting, the electorate of the district authorized the board to borrow an adaitional $\$ 17,000.00$. This sum exceeded the 5 per cent limit of peraitted indebtedness. The board borrowed the noney from resident taxpayers of the district and issued promissory notes at 6 per cent interest. The school district board paid the interest for a 16-year period, as well as part of the principal. This suit was filed for the balance of the principal. The Court stated:

... the loans frow the plaintiff to the defendant school district in November and December, 1924 were void because all the indebtedness thus incurred together with the existing indebtedness of the school district exceeded five per cent of the then taxable property as ascertained by the last assessment for state and county taxes, and that any renewals of said loans are likewise void and the defendant is entitled to judgment against the plaintiff dismissing the conplaint with cos\%s. 40

In Florivi, the Supreme Court ruled on the validity of loans made to construct and purchase teachers' homes in Taylor $v$. Board of Public Instruction of Lafayette County. 41 This action was filed to stop payment of the loan on the grounds that public funcis could not be used for such purposes since express authority for such construction was not stipulated. The court ruled:

40 Ibid.

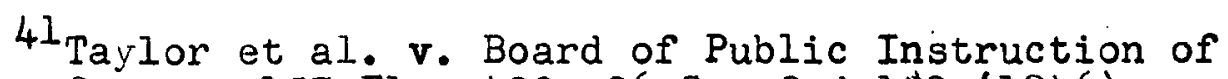
Lafayette County, 157 Fla. 422, 26 So. 2nd 180 (1946). 
It is still the law that public school funds be safeguarded and kept inviolate for the purpose designed; at the same ti:ne, "athletic fields," "gymnasiums," "bus sheds," "teachers' homes," and the many other adjuncts have been declared by the Legislature to be necessary to an adequate public school plant.... Expenditures for them are safeguarded in that they must be approved by the State Board of Education. 42

The legality of tax anticipation warrants for obligations yet to be incurred was in question before the California suprene court several years ago. 43 The county treasurer refused to sign the warrants on the grounds that tax anticipation warrants were to be issued for obligations already incurred and not for obligations in the future. The Court ruled that such warrants for future obligations were legitinate.

The Justices of the Supreme Court of liew Harnpshire were asked to rule on the combining of indebtedness allowed to a school district and that allowed to towns, all to be used for school purposes. 44 They ruled, "Towns may not borrow money for school purposes under present statutes. Such powers reside in the school districts. 145

In the case of Pullum v. Consolidated School District

42 Ibid.

43 Berkeley High School District of Alameda County v. Coit, 7 Cal. 2nd 132, 59 P. 2nd 992 (1936).

44 Opinions of the Justices, Supreme Court of New Hampshire, 94 N.H. 499, 51 A. 2nd 840 (1947). ${ }^{45}$ Ibid. 
No. 5, Stoddard County, ${ }^{46}$ the Missouri Supreme Court ruled that school districts are political subdivisions of the state and debts incurred are state debts, which fall under a ten-year expiration limit rather than the five-year limit as contested by the school board who refused to pay off a loan.

INVESTHENT OF SCHOOL DISTRICT FUINDS

This section of the study examines the statutory provisions relating to the investment of "surplus funds" by school districts. Surplus funcis are defined as funds that are not needed innediately for the current operation of the school district. These inay be funds that have been collected especially for a specific purpose, or may be an accumulation of funds not needed in the foreseeable future. School districts acquire surplus funds usually under the following conditions:

1. From the sale of school district bonds or from equipment no longer needed

2. Fron the sale of school lands or other district property

3. Funds accurnlated in "sinking funds" for the payment of outstandine district obligations

4. Funds that have been appropriated to the credit of the district and for some reason are not needed for current operations

46 Pullum v. Consoliciated School District No. 5, Stoddard County, 357 ivo. 858,211 S.W. 2nd 30 (1948). 
5. Funds accumulated for the purpose of proposed construction, usually referred to as "building funds."

These are the funds that are usually available to

the school district for investment purposes. This section examines the statutóry provisions regariing the procedures to be followed in investing these funds, the anount of money that can be invested, and the type of investments permitted by statute.

The tern investment, as used in this section, means the placing of school district funds in long-term obligations sucin as bonds and securities. The placing of funds in a local bank for short periocis of tine is not regarued as "investment of funds" for purposes of this study.

Table XVII examines the statutory provisions governing the approval required before school districts may invest funds. Three states -- Alabama, Alaska, Delaware-- do not have statutory provisions permitting school districts to invest funds. Georgia, Indiana, Iowa, Ohio, and Colorado require state agency aproval before being permitted to invest surplus funds. In Colorado the sitate Board of Land Conmissioners makes the approval, while in Georgia it is the State School Building Authority. Indiana and Iowa must have the approval of the state Board of Finance, and the Ohio statute requires the chief state school officer to approve investment of school district funds.

Several of the states require local agency approval before surplus funcis may be invested by local school districts. 
TABLE XVII

STATUTORY PROVISIONS GOVERNING THE APPROVAL OF INVESTMENT OF SCHOOL FUNDS BY SCHOUL DIOTRICTS

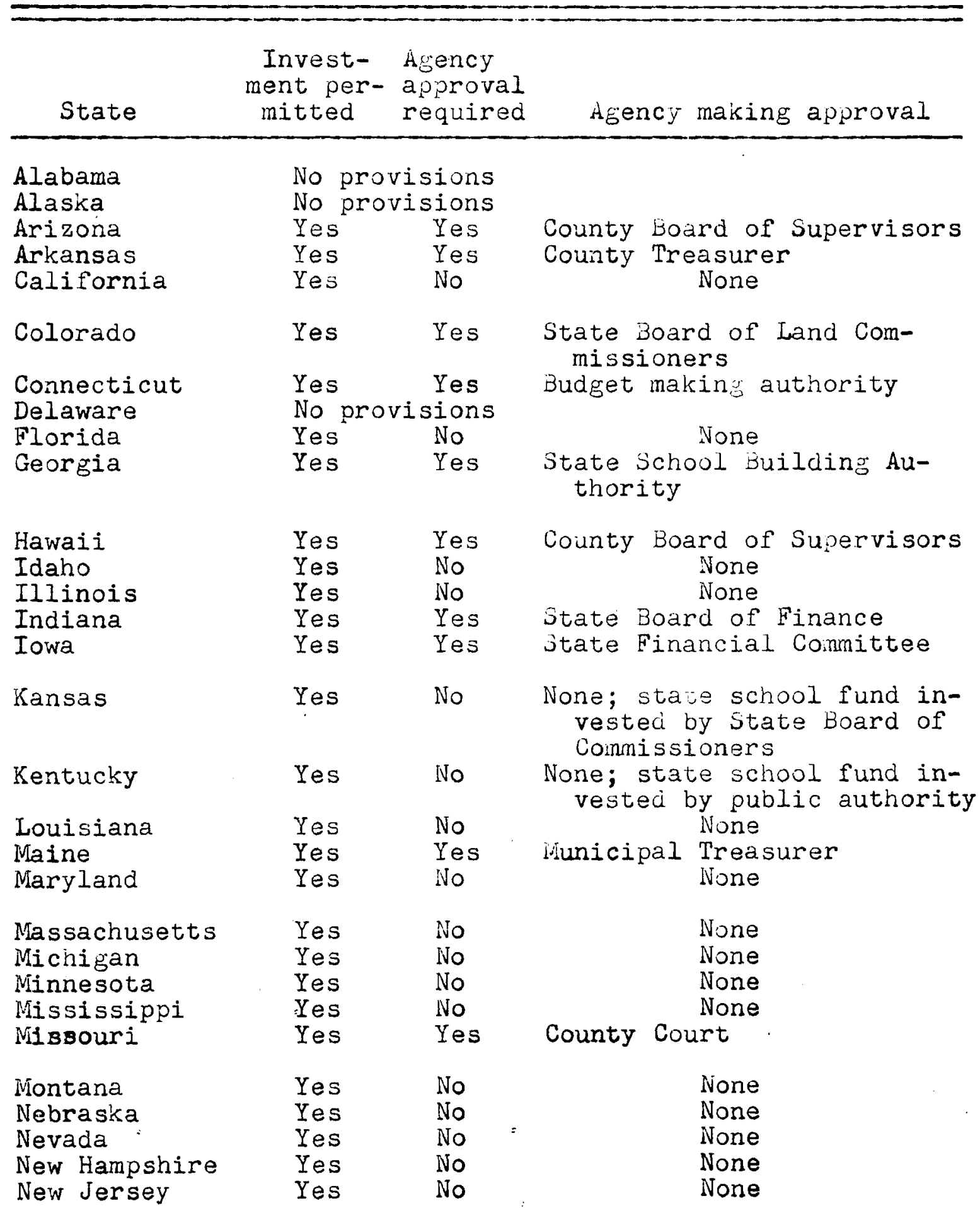




\begin{tabular}{|c|c|c|c|}
\hline State & $\begin{array}{l}\text { Invest- } \\
\text { ment per- } \\
\text { mitted }\end{array}$ & $\begin{array}{l}\text { Agency } \\
\text { approval } \\
\text { required }\end{array}$ & Agency making approval \\
\hline $\begin{array}{l}\text { New Nexico } \\
\text { New York } \\
\text { North Carolina } \\
\text { North Dakota } \\
\text { Ohio }\end{array}$ & $\begin{array}{l}\text { Yes } \\
\text { Yes } \\
\text { Yes } \\
\text { Yes } \\
\text { Yes }\end{array}$ & $\begin{array}{l}\text { Yes } \\
\text { No } \\
\text { No } \\
\text { No } \\
\text { Yes }\end{array}$ & $\begin{array}{c}\text { County Board of Finance } \\
\text { None } \\
\text { None } \\
\text { None } \\
\text { State Superintendent }\end{array}$ \\
\hline $\begin{array}{l}\text { Oklahoina } \\
\text { Oregon }\end{array}$ & $\begin{array}{l}\text { Yes } \\
\text { Yes }\end{array}$ & $\begin{array}{l}\text { No } \\
\text { Yes }\end{array}$ & $\begin{array}{l}\text { None } \\
\text { Board of Common School Fund } \\
\text { in special districts }\end{array}$ \\
\hline $\begin{array}{l}\text { Pennsylvania } \\
\text { Rhode Island } \\
\text { South Carolina }=\end{array}$ & $\begin{array}{l}\text { Yes } \\
\text { Yes } \\
\text { Yes }\end{array}$ & $\begin{array}{l}\text { No } \\
\text { No } \\
\text { No }\end{array}$ & $\begin{array}{l}\text { None } \\
\text { None } \\
\text { None }\end{array}$ \\
\hline $\begin{array}{l}\text { South Dakota } \\
\text { Tennessee } \\
\text { Texas } \\
\text { Utah } \\
\text { Vermont }\end{array}$ & $\begin{array}{l}\text { Yes } \\
\text { Yes } \\
\text { Yes } \\
\text { Yes } \\
\text { Yes }\end{array}$ & $\begin{array}{l}\text { No } \\
\text { Yes } \\
\text { No } \\
\text { No } \\
\text { No }\end{array}$ & $\begin{array}{ll}\text { Quarterly } & \text { None } \\
& \text { Nourt } \\
\text { INone } \\
\text { None }\end{array}$ \\
\hline Virginia & Yes & Yes & $\begin{array}{l}\text { Circuit Judge or County } \\
\text { Attorney, depending on } \\
\text { fund }\end{array}$ \\
\hline $\begin{array}{l}\text { Washington } \\
\text { West Virginia }\end{array}$ & $\begin{array}{l}\text { Yes } \\
\text { Yes }\end{array}$ & $\begin{array}{l}\text { No } \\
\text { Yes }\end{array}$ & $\begin{array}{l}\text { None } \\
\text { State jinking Fund Connis- } \\
\text { sion }\end{array}$ \\
\hline $\begin{array}{l}\text { Wisconsin } \\
\text { Wyoming }\end{array}$ & $\begin{array}{l}\text { Yes } \\
\text { Yes }\end{array}$ & $\begin{array}{l}\text { No } \\
\text { No }\end{array}$ & $\begin{array}{l}\text { None } \\
\text { None }\end{array}$ \\
\hline
\end{tabular}


In Arizona and Hawaii the County Board of Supervisors must approve the investments. The County Treasurer performs this function in Arkansas, and in New vilexico it is the County Finance Board. The municipal treasurer approves the investment of funds in ilaine, and the local budget-rnaking authority approves investments in Connecticut.

The equarterly Court --composed of the county judge, county clerk, and county school superintendent-- approves local school district investments in Tennessee. In Virginia, approval may be by either the circuit judige or the county attorney, depending on the fund to be invested. The Oregon statutes have set up a Board of Conmon School Funds for approval of funds in special school districts.

Table XVIII exanines the statutory provisions governing the types of investinents permitted, and the amount of funds perinitted to be invested by the several states. In most instances, investments of surplus funds by school districts are restricted to United states obligations, state obligations, or obligations of the various political subdivisions of tine state in question.

The states of California, Colorado, Hawaii, Idaho, Illinois, Kansas, Louisiana, Waine, Waryland, Michigan, New Mexico, Pennsylvania, Tennessee, Texas, Wisconsin, and Wyoming have statutory provisions permitting the investment of "any surplus funds." Pennsylvania, in this group, provides for the investment of "any funis" for the "best advantage 


\section{TABLA XVIII}

STATUTORY PROVISIUNS GOVRRNING THE TYPE AND ANOUNT OF SCHOUL DISTRILT INVESTIENTS PERUITTED

\begin{tabular}{|c|c|c|}
\hline State & Type of investnent pernitted & $\begin{array}{l}\text { Amount permitted } \\
\text { to be invested }\end{array}$ \\
\hline Alabama & No provisions & \\
\hline Alaska & No provisions & \\
\hline Arizona & U.S. and political subdivision notes & $\begin{array}{l}\text { Bond proceeds not needed for } \\
\text { period of } 3 \text { months }\end{array}$ \\
\hline Arkansas & Type not stipuiated & The equalization funds \\
\hline California & General obligations of the U.S. & Any surplus money \\
\hline Colorado & $\begin{array}{l}\text { Obligations of tre state and polit- } \\
\text { ical subdivisions }\end{array}$ & All school funuis \\
\hline $\begin{array}{l}\text { Connecticut } \\
\text { Delaware }\end{array}$ & $\begin{array}{l}\text { Any investment } \\
\text { No provisions }\end{array}$ & Not stipulated \\
\hline Florida & $\begin{array}{l}\text { U.S., school district, and state } \\
\text { board of education notes }\end{array}$ & Proceedis from bond sales \\
\hline Georgia & $\begin{array}{l}\text { Bonds of State School Building } \\
\text { Autiority }\end{array}$ & Not stipulated \\
\hline Hawaii & U.S. and state boncis & AIl extra funcis \\
\hline Idaho & U.S., state, and county obligations & Surplus funds \\
\hline Illinois & $\begin{array}{l}\text { U.S., state, and municipal obli- } \\
\text { gations }\end{array}$ & School funcis \\
\hline Indiana & $\begin{array}{l}\text { U.S. state, and municipal obli- } \\
\text { gations }\end{array}$ & County school fund \\
\hline Iowa & U.S., state, and county obligations & The state school fund \\
\hline
\end{tabular}


TABLE XVIII (cont.)

\section{State}

Kansas

Kentucky

Louisiana

Maine

Maryland

Massachusetts

Michigan

Winnesota

Mississipi

Missouri

Montana

Nebraska

Nevada

New Hampshire

New Jersey

New inexico

New York

North Carolina

North Dakota

Ohio

Oklahoma

Oregon
Type of investment permitted

Amount permitted

to be invested
U.S., state subdivision obligations

U.S. obligations

U.S. obligations

Obligations of political subdivisions

U.S., state obligations

Varied in statutes

U.3. obligations

U.S., state obligations

U.S., state, municipal obligations

U.S., state obligations

U.S., state obligations

U.S., state, county obligations

U.S. obligations

Not stipulated

U.S., state, municipal obligations

U.S., state, municipal obligations

U.S., state obligations

U.S., state, municipal obligations

Varied list

U.S., state obligations

U.S. obligations

U.S. obligations
Surplus funds in subdivisions below $15 \%$ debt limit Not stipulated Any surplus funds

Bond sales and others Sinking funds and other

80\% of some funds

Any funảs

Not stipulated

Excess funds not needed

for three months

Funds not neecied for six months

Not stipulated

Not stipulated

State funds and sinking funds

Trust funus

Not stipulated

All public funcis

All funds except loan and reserve funds

Capital reserve funds

Varied list in statutes

Sinking and construction funds

Bond sales, building and sinking funds

Not stipulated 
TABLE XVIII (cont.)

\section{State}

Pennsylvania
Rhode Island
South Carolina
South Dakota
Tennessee

Tennessee

Texas
Utah
Vermont
Virginia
Washington
West Virginia
Wisconsin
Wyoming

Type of investment permitted

For best advantage of school

$$
\text { district }
$$

Not stipulated

U.S. obligations

Varied list

U.S. obligations

U.S. obligations

U.S., state, municipal obligations

Varied with the fund to be invested

U.S., state, municipal obligations

varied with the district

State Sinking Fund Commission invests

U.S., state subdivisions obligations

Varied list in statutes
Amount permitted to be invested 
of the school district," indicating very few statutory restrictions.

States other than those listed above have statutory provisions limiting the amount of funds that can be invested or the fund thet nay be invested. The reader is referred to Table XVIII for the statutory provisions of any individual state.

\section{SUMMARY}

School districts, as quasi-corporations, have very limited powers. They have only such powers as are conferred by statute or are closely implied from them. Power to contract deut in any foril, for exainple, must be conferred by statute or by constitutional enactment and must be exercised as the provisions specify.

Long experience indicates that debt management is one of the most difficult areas in local school district operation. As a result, le islatures are much concerned about controlling the contract of debt by school districts, either by statute or through the supervisory control of state arencies which are designated and authorized by the legislatures to exercise tinis control.

1. All states have provisions vermitting the issuance of long-term obligation bonds. The purpose for which these obligations may be incurred is usually limited to the repair and construction of school buildings. Some states 
permit school bonds to be issued for the purchasing of transportation equipment and for obtaining emergency funds. While compliance with the statutory provisions for the issuance of school bonds is mandatory, "substantial" compliance with statutory provisions has been held to satisfy statutory requirements in many instances.

2. The approval of a proposed bond issue by some state agency is not cominon among the states. A few require state agency approval of proposed bond issues (2) to see that the proposed issue meets the leral requirements of the statutes, (b) to assure efficient educational administration, anci (c) to require the proposal to be sound fiscally. The state agency most frequently designated to approve proposed bond issues is the state educational authority, although the state attorney general or other state agency has this responsibility in some instances.

3. The procedures to be followed in issuing bonds usually are set lown in detail in the statutory provisions granting this authority to school districts. The provisions must be complied with. They usually include: (a) a resolution by the governing board of the district, or a petition by the legal voters of the district, asking for the bond issue, (b) the holding of a "school bond election," (c) the establishing of the legality and validity of the bonds by a specified agency, and (d) the sale of the bonds on a competitive bidding basis. 
4. Most of the states have statutory or constitutional linitations on the amount of bonds that may be issued, as well as the maximum interest rate jermitted and the term the bonds may run. The provisions regarding limitations vary from a 2 per cent limit of the last assessed valuation to no limit (any limit in this case approved by a vote of the electorate). There is currently a variation in the maximurn rate pernitted from $3 \frac{1}{2}$ per cent to 8 per cent. The maximum tine period bonds may run varies from 20 years to 50 years.

5. Most of the states have statutory provisions expressly granting to school districts the right to borrow funds for short periods of time, commonly referred to as short-term loans. Short-term school district loans are of three types: tax anticipation warrants, promissory notes, and registered warrants. Some states permit more than one type of loan. A few require state agency approval of proposed short-term loans. Of the states requiring state agency approval, the most frequently used agency is the state educational authority, but a few states require approval by the state finance departinent.

6. Most of the states permit the investinent of school district surplus funds under statutory provisions. Few of the states require state agency approval for the investment of surplus funcis. When this is required, the most frequently used agency is the state finance department. 
Investments by school districts are restricted to those listed in the statutes. The type of investment permitted by school districts varies with the state; but the most common investments approved are in obligations of the federal government, state governments, and tire political subdivisions of the state. A few states have provisions which read "any investment" or investments "for the best advantage of the school district." The amount of surplus funds permitted to be invested varies with individual states, and in some cases with classes of school districts within the states. 


\section{CHAPTER VI}

\section{SCHOOL DISTRICT AUXILIARY AGENCIES}

This chapter deals with the activities of a school district comnonly referred to as "auxiliary agencies." The items of expenditure in this category are from the educational program of a school district other than the instructional program. They include such activities as the extracurricular program, the school lunchroom, and the transportation of pupils. Because of the statutory provisions imposed by the states over the selection and adoption of textbooks, a section has been included in this chapter dealing with textbooks.

All these areas are of importance to the present study since state legislatures have imposed varied controls over the financial operations of these items. As school districts have increased in size, and school enrollments have continued to expand, state legislatures have found it necessary to impose restrictions regarding these auxiliary agencies in orcier to safeguard the public funcis involved. While some of these funds (for example, those of class organizations) are sometimes regarded as private rather than public funds, the financial administration of them is so interwoven with regular district finances, and in fact so 
great a public interest is attached to the management of all funds, that state regulation has been extended to cover their financial administration as well. Restrictions also have been placed on school districts in relation to these items to insure that the funds being expended are used in the most efficient and economical manner.

This section is concerned with an analysis of the statutory provisions to examine the extent of control placed by the state legislatures over the operation of auxiliary agencies by school districts.

\section{THE GENERAL BODY OF THE LAW}

"The manner in which school funds shall be collected and the board or officers who shall receive and have custody of such funds depends on the terms of the statutes relating thereto" states Corpus Juris Secundum ${ }^{2}$ in discussing student activity funds.

Extra-curricular funds collected from student activities are official school funds and must be treated as such:

Accounts created through extra curricular activities of students such as athletic and dranatic and musical enterprises at which fees were charged, must go into the official account of the district treasurer and are subject to audit. 2

$I_{79}$ C.J.S. Collection and Custody, par. 335 (1952). ${ }^{2}$ Ibid. , footnote no. 67 . 
The general body of the law relating to the operation and maintenance of a school cafeteria states:

A school cafeteria or a candy counter may be maintained, and the mere fact that lunches and refreshments are sold to teachers and pupils in order to furnish a safe and sanitary service and to aid in the conduct of the school is not an unlawful use of the building, even though some profit may be realized therefrom. 3

Corpus Juris Secundum discusses the sufficiency of transportation by saying:

Where a school board is required by statute to furnish transportation, within the limits of what is reasonable in compliance with the statute and not unreasonably discriminatory, it should be left to the board to determine the route and the time and places for gathering up the children who are to be transported, and pupils may be required to walk a reasonable distance to a point along the established route. 4

\section{STUDENT ACTIVITY ACCOUNTS}

This section of the chapter is concerned primarily with the restrictions imposed by the state legislatures over the operation and maintenance of so-called "stucient activity accounts," "allied accounts," "extra-curricular accounts," or whatever terminology is used to designate receipts and expenditures carried on by a school apart from the regular instructional program. This inclucies funcis from athletic contests, club activities, dramatic and musical presentations,

${ }^{3} 78$ C. J.S. Control, Possession, and Use in General, par. $259(1952)$. (1952).

479 C.. J.S. Sufficiency of Transportation, par. 481 
school publications, and any other student endeavors.

In the absence of express statutory provisions, student activity accounts have no legal existence. During the trying economic times of the $1930^{\prime} \mathrm{s}$, complaints developed in a number of states that individuals responsible for stucient activity money were not hanciling it properly. As a result, several states enacted legislation for their proper accounting and reporting.

One of the practices of conducting an efficient business is to provide for periodic checks or audits of the financial transactions being carried on. Since student activity tranjactions in most schools involve considerable sums of money, it seems logical that state legislatures would provide regulations for their proper accounting. The audit should be used as a means of assuring the public that student activity funcis are being properly managed. Audits should be conducted also for the following reasons: 5

1. To give assurance that the financial statements are correct

2. To prevent fraud

3. To detect fraud

4. To check on the consistency with which records are kept

5. To protect the chief. administrator

6. To make the general public feel that the schools are being given honest management.'

${ }^{5}$ Rosenstengel, loc. cit. 
It is the purpose of this section to examine the statutory provisions where student activity accounts are subject to audit, as well as an examination of the court decisions that have resulted in litigation over the management of student activity funds.

Table XIX presents a detailed analysis of the statutes of the various states requiring audits of student activity accounts. Seventeen of the 50 states make some mention in their statutes of stucient activity money and the proper accounting of such funds. No single pattern is followed with regard to the provisions for the inanaenent of student activity accounts.

Twelve of the 17 states provide for an annual audit of these accounts. They are: Arizona, California, Connecticut, Hawaii, Kansas, Viaryland, Ninnesota, Vijsissippi, North Carolina, Oklahona, Pennsylvania, and South Dakota. Maryland provides for an annual aucit to be conducted if the funds involved are in excess of $\$ 250.00$. Kansas has an annual audit for school districts belonging to the state athletic association, while vississippi statutes provide for an audit of funds from "athletic affairs" only.

Idaho provides for a biennial audit; New York and Tennessee have statutes in which the frequency of the audit is not stipulated.

Arizona, California, and Uinnesota provide for an audit to be conducted by a public accountant hired by the 
local board of education. The State Comptroller makes the annual audit in Hawai, and in Mississippi this is the responsibility of the State Auditor. Maryland has a provision whereby the person employed as auditor by the board of education must be approved by the State Superintendent. The statutes of New York, North Carolina, Oklahoma, South Dakota, and-Tennessee delegate the responsibility for the conduct of the audit to the local board of education. The individual responsible for the audit in Pennsylvania is varied, depending on the class or size of school district under consideration. In Connecticut the town auditor audits activity accounts in the "same manner as all other town accounts."

The Florida statutes mention activity funds in reference to "proper accounting procedures" only, and in Indiana the State Board of Accounts will examine the records when "in the judgment of the State Examiner such examination is necessary."

\section{Applicable Court Decisions}

It has been held on occasion that in the absence of express statutory provision, funds from student activity endeavors are considered official school accounts and are subject to audit. In an action by the auditor of Hatfield Consolidated School Board, ${ }^{6}$ a Pennsylvania court ruled:

${ }^{6}$ Petition of Auditors of Hatfield Tp. School Dist., $161 \mathrm{~Pa}$. Super. 388, $54 \mathrm{~A}$. 2nd 833 (1947). 
TABLE XIX

PROVISIONS GOVERNING SCHOOL ACTIVITY ACCOUNTS IN STATES IMPOSING STATUTORY REGULATION

\begin{tabular}{|c|c|c|c|}
\hline State & $\begin{array}{l}\text { Audit } \\
\text { required }\end{array}$ & $\begin{array}{l}\text { Frequency } \\
\text { of audit }\end{array}$ & $\begin{array}{l}\text { Agency responsible } \\
\text { for conduct of audit }\end{array}$ \\
\hline $\begin{array}{l}\text { Arizona } \\
\text { California } \\
\text { Connecticut } \\
\text { Florida } \\
\text { Hawaii }\end{array}$ & $\begin{array}{l}\text { Yes } \\
\text { Yes } \\
\text { Yes } \\
\text { No } \\
\text { Yes }\end{array}$ & $\begin{array}{l}\text { Annually } \\
\text { Annually } \\
\text { Annually } \\
\text { None } \\
\text { Annually }\end{array}$ & $\begin{array}{l}\text { PA } \\
\text { CPA or PA } \\
\text { Town auditor } \\
\text { County Superintendent } \\
\text { State Comptroller }\end{array}$ \\
\hline $\begin{array}{l}\text { Idaho } \\
\text { Indiana }\end{array}$ & $\begin{array}{l}\text { Yes } \\
\text { No }\end{array}$ & $\begin{array}{l}\text { Biennially } \\
\text { When } \\
\text { necessary }\end{array}$ & $\begin{array}{l}\text { School Board employe } \\
\text { State Board of } \\
\text { Accounts }\end{array}$ \\
\hline $\begin{array}{l}\text { Kansas } \\
\text { Maryland } \\
\text { Minnesota }\end{array}$ & $\begin{array}{l}\text { Yes } \\
\text { Yes } \\
\text { Yes }\end{array}$ & $\begin{array}{l}\text { Annually } \\
\text { Annually } \\
\text { Annuálly }\end{array}$ & $\begin{array}{l}\text { Not stipulated } \\
\text { Accountant } \\
\text { State Examiner or CPA }\end{array}$ \\
\hline $\begin{array}{l}\text { Mississippi } \\
\text { New York } \\
\text { North Carolina } \\
\text { Oklahoma } \\
\text { Pennsylvania }\end{array}$ & $\begin{array}{l}\text { Yes } \\
\text { Yes } \\
\text { Yes } \\
\text { Yes } \\
\text { Yes }\end{array}$ & $\begin{array}{l}\text { Annually } \\
\text { Varied } \\
\text { Annually } \\
\text { Annually } \\
\text { Annually }\end{array}$ & $\begin{array}{l}\text { State Auditor } \\
\text { Board of Education } \\
\text { Board of Education } \\
\text { Board of Education } \\
\text { Varied with district }\end{array}$ \\
\hline $\begin{array}{l}\text { South Dakota } \\
\text { Tennessee }\end{array}$ & $\begin{array}{l}\text { Yes } \\
\text { Yes }\end{array}$ & $\begin{array}{l}\text { Annually } \\
\text { Varied }\end{array}$ & $\begin{array}{l}\text { Board of Education } \\
\text { Board of Education }\end{array}$ \\
\hline
\end{tabular}

$a_{\text {The abbreviations } P A}$ and CPA refer to public accountant and certified public accountant, respectively. 
Accounts of joint consolidated school districts, created through extra-curricular activities of students, such as athletic and dramatic and musical enterprises at which admission fees were charged, must go into official account of district treasurer, and are subject to audit.7

Part of a case, in which an unsuccessful attempt was made to remove school directors from office because of their failure to secure bids for payment of athletic equipment, involved the school directors' setting up a separate board of control of extra-curricular activities. This board approved expenditures without following statutory provisions for competitive bidding. The court ruled:

The school board may hereafter continue to permit the athletic board of control to manage and direct extracurricular activities, but all moneys received therefrom and all expenditures for equipment to be used therein, must be reported to and approved by the board of directors as a board. 8

A number of cases have reached the courts in which athletic goods companies have atteipted to recover anounts on goods sold to various school officials for use in the extra-curricular progran. In Lowe and Campbell Athletic Goods Co. V. Nunn, 9 Nunn as superintendent ordered some $\$ 3,066.42$ worth of goods over a ten-year period and paid out of activity funds $\$ 1,809.20$. This suit was filed to collect

\section{${ }^{7}$ Ibid.}

${ }^{8}$ In re German Township School Directors, $46 \mathrm{~Pa}$. D.\&C. $562(1942)$.

${ }^{9}$ Lowe and Campbell Athletic Goods Co. v. Nunn, 182 Okla. 304, 77 P. 2nd 738 (1938). 
the balance. It was brought out in the case that the Company understood that payment for the goods would be made out of the student activity fund. As to Nunn's liability the court said:

It is true, as agreed by the plaintiff, that the "student activity fund" has no legal status and cannot be sued. Yet, under the finding of the court, this fact was known to the plaintiff, and it was willing to look to the fund alone for payment, and it agreed not to hold the defendant personally liable. Under such circumstances the understanding of the parties will be given effect, the presumption that plaintiff intended to hold the superintendent as principal will not be indulged, and the defendant will not be personally liable. 10

In other actions involving the Lowe and Carnpbell Company they were successful in collecting from the school board, and not from the principal who ordered the equipment. ${ }^{11}$ The Company was successful in the above case in collecting from the school board in the absence of statutory provisions giving lesal basis to the student activity account. The school board was successful in securing insurance payments for athletic equipment destroyed in a fire. Since they cashed the check, the activity and the account became recognized by the courts.

The Utah court, in Beard v. Board of Education, 12

\section{${ }^{10}$ Ibid.}

${ }^{11}$ Lowe and Campbell Athletic Company v. Tangipahoa Parish School Board et al., 32 So. 2nd 84 (1947). See also Lowe and Campbell Athletic Goods Company v. Tangipahoa Parish School Board, 207 La. 52, 20 So. 2nd 422 (1947). 12 Beard v. Board of Education, 81 Utah 51, 16 P. 2nd 900 (1932). 
acknowledged the existence of the student activity fund in the absence of express statutory provisions.

In a recent case in South Carolina, ${ }^{13}$ the Supreme Court ruled that in the absence of express statutory authority school activity accounts were subject to audit and held in trust for the people of the district by the fund trustee. The parents of the school district were successful in requiring a full and accurate accounting of said funds. The Court stated:

Generally - It is a strict ciuty of a trustee to keep and render a full and accurate record and accounting of his trusteeship to the cestui que trust, and the duty is strictly enforced by the courts. It is commonly governed by statutory provision. Such duty of the trustee is not affected by the fact that he voluntarily assumed the trust. A trustee by operation of law-constructive or resulting-- must account for and is chargeable with, subject to proper credits, property subject to trust. 14

Several of the cases discussed in this section were discussed earlier when dealing with the general school audit. Because of their significance to both sections under discussion, they have been repeated.

\section{SCHOOL CAFETERIAS}

As school districts continue to consolidate into

larger administrative units and school children must be

13 Betterson v. Steward, 238 S.C. 574, 121 S.E. 2nd 102 (1961).

${ }^{14}$ Ibid. 
transported in from longer distances, the local school district has an obligation to provide a wholesome, wellbalanced meal. School cafeterias have becone a big business in this nation, anc a larpe part of the school district's tine and noney will go into managing an efficient school lunch program.

This section of the study is concerned with the statutory provisions and court decisions relating to the operation of school cafeterias.

Table XX presents a detailed analysis of the statutory provisions relating to school lunchroom accounts in the 50 states. All statutory provisions governing school lunchroom accounts follow a similar pattern. All states participate in the ivational School Lunch Act which distributes foodstuffs to school districts in the 50 states. All states place the custody of federal funds allotted to the several states in the hands of the state treasurer. The only major difference in the statutory provisions enacted in the several states is the conduct of the audit. Two patterns are in operation. Where a local lunciroom account audit is not provided for, the state educational authorities supervise the operations of the school lunchroom. In the states stipulating an audit requirement, it is placed at the discretion of the state educational authorities. Hawai, the only state not conforming to one of these patterns, places the supervision of the school lunch 
TABLE XX

STATUTORY PROVISIONS GOVERNING SCHOUL LUNCH ACCOUNTS

\begin{tabular}{|c|c|c|}
\hline State & $\begin{array}{l}\text { Local audit } \\
\text { required }\end{array}$ & $\begin{array}{l}\text { Agency supervising program } \\
\text { or responsible for audit }\end{array}$ \\
\hline $\begin{array}{l}\text { Alabama } \\
\text { Alaska } \\
\text { Arizona } \\
\text { Arkansas } \\
\text { California }\end{array}$ & $\begin{array}{l}\text { No } \\
\text { No } \\
\text { Yes } \\
\text { Yes } \\
\text { No }\end{array}$ & $\begin{array}{c}\text { State Board } \\
\text { State Board } \\
\text { Discretion of State Board } \\
\text { Discretion of State Board } \\
\text { State Board }\end{array}$ \\
\hline $\begin{array}{l}\text { Colorado } \\
\text { Connecticut } \\
\text { Delaware } \\
\text { Florida } \\
\text { Georgia }\end{array}$ & $\begin{array}{l}\text { No } \\
\text { No } \\
\text { No } \\
\text { No } \\
\text { No }\end{array}$ & $\begin{array}{r}\text { State Commissioner } \\
\text { State Board } \\
\text { State Board } \\
\text { State Board } \\
\text { State Board }\end{array}$ \\
\hline $\begin{array}{l}\text { Hawaii } \\
\text { Idaho } \\
\text { Illinois } \\
\text { Indiana } \\
\text { Iowa }\end{array}$ & $\begin{array}{l}\text { No } \\
\text { No } \\
\text { No } \\
\text { Yes } \\
\text { Yes }\end{array}$ & $\begin{array}{l}\text { State Administration Department } \\
\text { State Board } \\
\text { State Superintendent } \\
\text { Discretion of State Board } \\
\text { Discretion of State Board }\end{array}$ \\
\hline $\begin{array}{l}\text { Kansas } \\
\text { Kentucky } \\
\text { Louisiana } \\
\text { Maine } \\
\text { Maryland }\end{array}$ & $\begin{array}{l}\text { Yes } \\
\text { No } \\
\text { Yes } \\
\text { Yes } \\
\text { No }\end{array}$ & $\begin{array}{c}\text { Discretion of State Board } \\
\text { state Board } \\
\text { Discretion of State Board } \\
\text { Discretion of state Commissioner } \\
\text { State Board }\end{array}$ \\
\hline $\begin{array}{l}\text { Miassachusetts } \\
\text { Michigan } \\
\text { Minnesota } \\
\text { Mississippi } \\
\text { Missouri }\end{array}$ & $\begin{array}{l}\text { No } \\
\text { No } \\
\text { No } \\
\text { No } \\
\text { No }\end{array}$ & $\begin{array}{l}\text { State Commissioner } \\
\text { State Board } \\
\text { State Board } \\
\text { State Department of Education } \\
\text { State Board }\end{array}$ \\
\hline $\begin{array}{l}\text { Montana } \\
\text { Nebraska } \\
\text { Nevada } \\
\text { New Hampshire } \\
\text { New Jersey }\end{array}$ & $\begin{array}{l}\text { No } \\
\text { No } \\
\text { Yes } \\
\text { No } \\
\text { No }\end{array}$ & $\begin{array}{c}\text { State Superintencient } \\
\text { State Board } \\
\text { Discretion of State Board } \\
\text { State Board } \\
\text { State Board }\end{array}$ \\
\hline $\begin{array}{l}\text { New Nexico } \\
\text { New York } \\
\text { North Carolina } \\
\text { North Dakota } \\
\text { Ohio }\end{array}$ & $\begin{array}{l}\text { Yes } \\
\text { No } \\
\text { No } \\
\text { Yes } \\
\text { Yes }\end{array}$ & $\begin{array}{c}\text { Discretion of state Board } \\
\text { State Board } \\
\text { State Board } \\
\text { Discretion of state Board } \\
\text { Discretion of State Board }\end{array}$ \\
\hline
\end{tabular}


TABLE XX (cont.)

\begin{tabular}{|c|c|c|}
\hline State & $\begin{array}{l}\text { Local audit } \\
\text { required }\end{array}$ & $\begin{array}{l}\text { Agency supervising program } \\
\text { or responsible for audit }\end{array}$ \\
\hline $\begin{array}{l}\text { Oklahoma } \\
\text { Oregon } \\
\text { Pennsylvania } \\
\text { Rhode Island } \\
\text { South Carolina }\end{array}$ & $\begin{array}{l}\text { No } \\
\text { No } \\
\text { Yes } \\
\text { Yes } \\
\text { No }\end{array}$ & $\begin{array}{l}\text { State Board } \\
\text { State Superintendent } \\
\text { Discretion of State Board } \\
\text { Discretion of State Board } \\
\text { State Board }\end{array}$ \\
\hline $\begin{array}{l}\text { South Dakota } \\
\text { Tennessee } \\
\text { Texas } \\
\text { Utah } \\
\text { Vermont }\end{array}$ & $\begin{array}{l}\text { No } \\
\text { No } \\
\text { No } \\
\text { No } \\
\text { No }\end{array}$ & $\begin{array}{l}\text { State Board } \\
\text { State Board } \\
\text { State Board } \\
\text { State Board } \\
\text { State Board }\end{array}$ \\
\hline $\begin{array}{l}\text { Virginia } \\
\text { Washington } \\
\text { West Virginia } \\
\text { Wisconsin } \\
\text { Wyoming }\end{array}$ & $\begin{array}{l}\text { No } \\
\text { No } \\
\text { No } \\
\text { No } \\
\text { Yes }\end{array}$ & $\begin{array}{c}\text { State Board } \\
\text { State Board } \\
\text { State Board } \\
\text { State Superintendent } \\
\text { Discretion of State Board }\end{array}$ \\
\hline
\end{tabular}


program with the State Department of Administration, as it does with many other aspects of school operations covered in this study.

The states of Arizona, Arkansas, Indiana, Iowa, Kansas, Louisiana, Haine, Nevada, New ivexico, North Dakota, Ohio, Pennsylvania, Rhode Island, and Wyoming have a required audit at the discretion of the state educational authorities. The other states do not have statutory provisions indicating that school lunchroom accounts must be audited.

In most states, statutory provisions are written to the effect that school districts must conform to the rules and regulations provided by the federal government in order to participate in the federal lunch act. Two sections of the National jchool Lunch Act place certain restrictions on the states and local school districts, and are of concern to this study:

Lunches served by schools participating in the school lunch program under this act shall meet mimimum nutritional requirements prescribed by the Secretary on the basis of tested nutritional research. Such meals shall be served without cost or at a reduced cost to children who are determined by local school authorities to be unable to pay the full cost of the lunch. No physical segregation of or other discrimination against any child shall be made by the school because of his inability to pay. School-lunch programs under this act shall be operated on a non-profit basis. Wach school shall, insofar as practicable, utilize in its lunch program commodities designated from time to tine by the Sevretary as being in abundance, either nationally or in the school area, or commodities donated by the Secretary ....15

${ }^{15}$ U.S. Code Congressional Service, 79 th Congress, Second session, 1946, p. 224, Sec. 9 . 
States, state educational agencies, and schools participating in the school-lunch program uncier this act shall keep such accounts and records as may be necessary to enable the Secretary to determine whether the provisions of this act are being complied with. Such accounts and records shall, at all times be available for inspection and audit by representatives of the Secretary anci shall be preserved for such period of time, not in excess of five years, as the Secretary determines is necessary ....16

The Secretary referred to in. the above act is the Secretary of Agriculture. The state educational authorities have the discretion to require accounts of funds and foods used on forms they themselves prescribe. School district records shall be open to inspection at all times and preserved for a minimum period of five years.

Applicable Court Decisions

Court decisions involving the operation of school Iunchrooms have centered around the problem of whether or not the local board of education has the power, either expressly granted or implied, to use the school buildings for lunchroom operations. The cases before the courts have involved merchants seeking actions to enjoin school districts from lunchroom operations on the grounds of violation of the Fourteenth Amendment (due process) or that the merchant is injured financially because of the "business" of school cafeteria operation.

In the Louisiana case of Ralph v. Orleans Parish

$$
{ }^{16} \text { Ibid., Sec. } 11(a) .
$$


School Board, 17 the State Supreme Court ruled in 1925:

Our conclusion is that the mere sale of luncheons, etc., on the school premises, during lunch hours only, to teachers and pupils only uncier the circumstances and for the purposes set forth in defendant's answer, is only incidental to the main purpose of said schools, and is in the interest of the safe, sanitary, and efficient conciuct of said schools, and that same is not an unlawful use of said buildings under such circum-

In an action in Colorado in 1929, where the merchant claimed violation of the due process of law clause in the Fourteenth Amendment, the U.S. Circuit Court of Appeals held:

The school board does not conduct these cafeterias for profit and in comnercial competition with private restaurants and eating houses. The students are kept in during the Iunch hour for reasons which iminediately concern their welfare as students. In conjunction with this administrative rule, the cafeterias are necessary conveniences.19

In Texas suit was brought against the board of education, superintencient of schools, and principal of a school which sold lunches as well as school supplies for emergency purposes. 20 The court ruled: "The cafeteria is a necessary convenience and is not obnoxious to any Constitutional or

17 Ralph v. Orleans Parish School Board, $158^{\circ} \mathrm{La} .659$, 104 So. 490, 52 ALR $253(1925)$.

18 Ibid.

19 Goodman v. School District No. I, City and County of Denver et al., 32 F. 2nd 586, 63 A.L.R. 92 (1929). (1931).

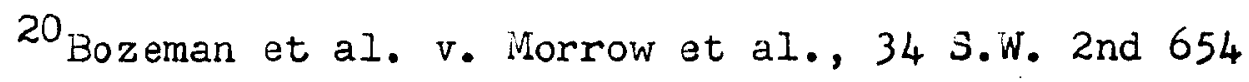


statutory inhibitions, and, we think, a reasonable exercise of the discretionary power conferred by law upon the board of trustees." 21

That schaol districts have an implied power to operate school cafeterias was the ruling also of the supreme Court in Washington in Hempel v. School District No. 329.22 They stated:

There is no direct explicit statutory authorization giving to the directors power to permit the use of school buildings for anything else except the conduct of schools, but, as an incident to the general power to control the property, conduct the schools, and transact all necessary business, it would seem not unreasonable to hold that the directors have also the necessarily implied power to permit the use of school buildings for such student activities as they may find to be helpful and advantageous in educating those for whom the schools were established. 23

\section{TEXTBOOKS}

Although the selection, adoption, and use of a uniform series of textbooks falls under the instructional program of a school district, the financial administration of textbook accounts has concerned state authorities. Thus it is imperative to consider the controls exercised by the

\section{$21_{\text {Ibid. }}$}

22 Hempel v. School District No. $329^{\circ}$ of Snohomish County et al., 186 Wash. 684,59 F. 2nd $729(1936)$. See also Speyer v. School District, 82 Colo. 534, 261 P. 859,57 A.L.R. 203 (1927).

\section{Ibid.}


state over the textbook program.

Statutory provisions over the selection and adoption of a uniform series of textbooks were enacted by state legislatures to insure economical and efficient expenditure of school district funds. Provisions insisting on a guaranteed price, minimum time for which the books may be used before changing, and compliance with use of adopted books all contribute toward economical expenditure of school district funds. Statutory provisions related to the adoption and use of textbooks also exercise considerable control of the curriculum offered in the states. State legislatures have found it necessary to control the use of textbooks to insure that certain fundamental course content will be included.

Table XXI gives a detailed analysis of the statutory provisions governing the selection, adoption, and use of a uniform series of textbooks in the several states.

Twenty-eight states have statutes prescribing a uniform series of textbooks. Arizona, New ilexico, and Oregon limit prescribed textbooks to grades 1-ob. Alabama, Arkansas, California, Connecticut, Delaware, Florida, Georgia, Hawaii, Idaho, Indiana, Kansas, Kentucky, Louisiana, Mississipi, Nevada, North Carolina, Oklahoma, South Carolina, Tennessee, Texas, Utah, Virginia, West Virginia, and Wyoming prescribe a uniform series of textbooks to be used in grades 1-12. In Illinois, Michigan, itinnesota, ilissouri, Wontana, 
TABLE XXI

STATUTORY PROVISIONS GOVERINING TEXTBOOKS

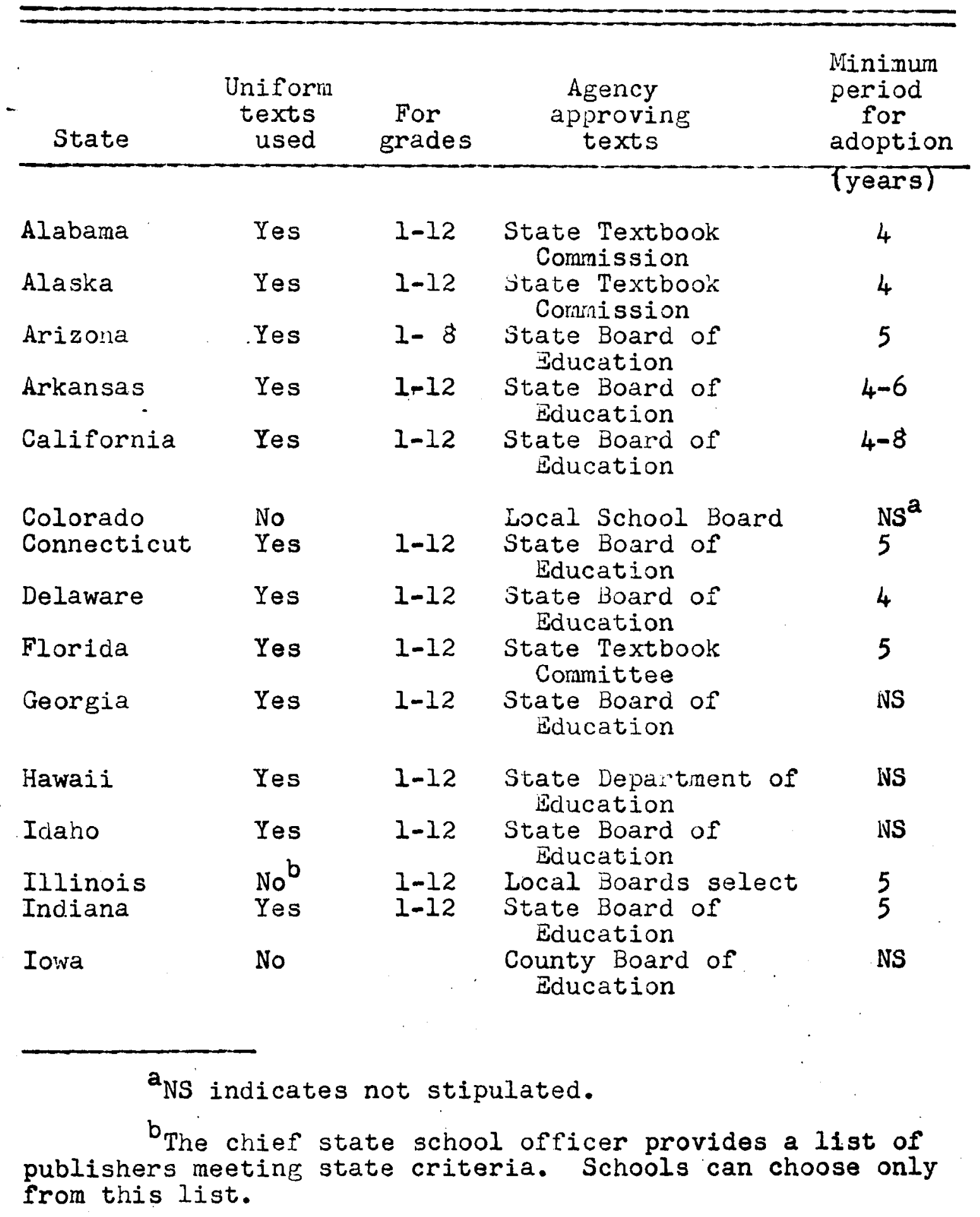


TABLE XXI (cont.)

\begin{tabular}{|c|c|c|c|c|}
\hline State & $\begin{array}{l}\text { Uniform } \\
\text { texts } \\
\text { used }\end{array}$ & $\begin{array}{l}\text { For } \\
\text { grades }\end{array}$ & $\begin{array}{l}\text { Agency } \\
\text { approving } \\
\text { texts }\end{array}$ & $\begin{array}{l}\text { inimum } \\
\text { eriod } \\
\text { for } \\
\text { option }\end{array}$ \\
\hline & & \multicolumn{3}{|c|}{ (years $)$} \\
\hline Kansas & Yes & $1-12$ & $\begin{array}{l}\text { 3tate Textbook } \\
\text { Commission }\end{array}$ & NS \\
\hline Kentucky & Yes & $1-12$ & State Textbook & 4 \\
\hline Louisiana & Yes & \multirow[t]{3}{*}{$1-12$} & $\begin{array}{l}\text { State Board of } \\
\text { Education }\end{array}$ & NS \\
\hline Maine & No & & $\begin{array}{l}\text { Local School Com- } \\
\text { mittee }\end{array}$ & NS \\
\hline Maryland & No & & County Superintendent & $t 3$ \\
\hline Massachusetts & No & \multirow{4}{*}{$1-12$} & $\begin{array}{l}\text { Local School Corn- } \\
\text { mittee. }\end{array}$ & NS \\
\hline $\begin{array}{l}\text { Michigan } \\
\text { Ninnesota }\end{array}$ & $\begin{array}{l}\text { Nob } \\
\text { Nob }\end{array}$ & & $\begin{array}{l}\text { Local Board } \\
\text { Local Board }\end{array}$ & $\begin{array}{l}5 \\
\text { NS }\end{array}$ \\
\hline Mississippi & Yes & & $\begin{array}{l}\text { State Textbook } \\
\text { Purchasing Board }\end{array}$ & NS \\
\hline Missouri & No ${ }^{b}$ & & $\begin{array}{l}\text { County Textbook } \\
\text { Committee }\end{array}$ & 5 \\
\hline $\begin{array}{l}\text { Montana } \\
\text { Nebraska }\end{array}$ & $\begin{array}{l}\text { Nob } \\
\text { No }\end{array}$ & \multirow{3}{*}{$1-12$} & $\begin{array}{l}\text { Local Board } \\
\text { Local Board }\end{array}$ & $\begin{array}{l}10 \\
\text { NS }\end{array}$ \\
\hline Nevada & Yes & & $\begin{array}{l}\text { State Textbook } \\
\text { Commission }\end{array}$ & NS \\
\hline $\begin{array}{l}\text { New Hampshire } \\
\text { New Jersey }\end{array}$ & $\begin{array}{l}\text { No } \\
\text { No }\end{array}$ & & $\begin{array}{l}\text { Local Board } \\
\text { Local Board }\end{array}$ & $\begin{array}{l}\text { NS } \\
\text { NS }\end{array}$ \\
\hline New ivexico & Yes & $1-8$ & $\begin{array}{l}\text { State Board of } \\
\text { Education }\end{array}$ & 6 \\
\hline New Yoris & No & \multirow{3}{*}{$1-12$} & Local Board & NS \\
\hline North Carolina & a Yes & & $\begin{array}{l}\text { State Board of } \\
\text { Education }\end{array}$ & 5 \\
\hline $\begin{array}{l}\text { North Dakota } \\
\text { Ohio }\end{array}$ & $\begin{array}{l}\text { Nob } \\
\text { Nob }\end{array}$ & & $\begin{array}{l}\text { Local Board } \\
\text { Local Board }\end{array}$ & $\begin{array}{l}4 \\
4\end{array}$ \\
\hline Oklahoma & Yes & $1-12$ & $\begin{array}{l}\text { State Textbook } \\
\text { Commission }\end{array}$ & 4 \\
\hline Oregon & Yes & $1-8$ & $\begin{array}{l}\text { State Textbook } \\
\text { Commission }\end{array}$ & 4 \\
\hline Pennsylvania & No & & $\begin{array}{l}\text { Local Board of } \\
\text { School Directors }\end{array}$ & 5 \\
\hline $\begin{array}{l}\text { Rhode Island } \\
\text { South Carolina }\end{array}$ & $\begin{array}{l}\text { No } \\
\text { a Yes }\end{array}$ & $1-12$ & $\begin{array}{c}\text { Local Board } \\
\text { State Textbook } \\
\text { Commission }\end{array}$ & $\begin{array}{l}3 \\
\text { NS }\end{array}$ \\
\hline
\end{tabular}


TABLE XXI (cont.)

\begin{tabular}{|c|c|c|c|c|}
\hline State & $\begin{array}{l}\text { Uniform } \\
\text { texts } \\
\text { used }\end{array}$ & $\begin{array}{l}\text { For } \\
\text { grades }\end{array}$ & $\begin{array}{l}\text { Agency } \\
\text { approving } \\
\text { texts }\end{array}$ & $\begin{array}{c}\text { Minimum } \\
\text { period } \\
\text { for } \\
\text { adoption }\end{array}$ \\
\hline & & & & (years) \\
\hline South Dakota & No & & $\begin{array}{l}\text { County Selection } \\
\text { Committee }\end{array}$ & NS \\
\hline Tennessee & Yes & $1-12$ & $\begin{array}{l}\text { State Textbook } \\
\text { Commission }\end{array}$ & $3-5$ \\
\hline Texas & Yes & $1-12$ & $\begin{array}{c}\text { State Textbook } \\
\text { Commission }\end{array}$ & 5 \\
\hline Utah & Yes & $1-12$ & $\begin{array}{c}\text { State Textbook } \\
\text { Commission }\end{array}$ & 4 \\
\hline Vermont & No & & Local Board & $\begin{array}{l}\text { At discre- } \\
\text { tion of } \\
\text { Local } \\
\text { Board }\end{array}$ \\
\hline Virginia & Yes & $1-12$ & $\begin{array}{l}\text { State Board of } \\
\text { Education }\end{array}$ & 6 \\
\hline $\begin{array}{l}\text { Washington } \\
\text { West Virginia }\end{array}$ & $\begin{array}{l}\text { No } \\
\text { Yes }\end{array}$ & $1-12$ & $\begin{array}{l}\text { County Textbook } \\
\text { State Board of } \\
\text { Education }\end{array}$ & $\begin{array}{r}3-5 \\
4\end{array}$ \\
\hline Wisconsin & No & & $\begin{array}{l}\text { County Textbook } \\
\text { Committee }\end{array}$ & 5 \\
\hline Wyoming & Yes & $1-12$ & $\begin{array}{l}\text { State Board of } \\
\text { Education }\end{array}$ & NS \\
\hline
\end{tabular}


North Dakota, and Ohio, the chief state school officer publishes a list of textbook publishers who have listed their books with his department, indicated a price, and supplied a bond. School districts must choose textbooks from the publishers placed on this list by the chief state school officer.

A state textbook commission selects the books for state board of education approval in the following states: Alabama, Alsska, Florida, Kansas, Kentucky, Nevada, Oklahoma, Oregon, South Carolina, Tennessee, Texas, and Utah. The State Board of iducation is the selection body in Arizona, Arkansas, California, Connecticut, Delaware, Idaho, Indiana, Louisiana, New ifexico, North Carolina, Virginia, West Virginia, and ifyoming.

The County Board of Aducation approves and selects books in Iowa; in ilissouri, South Dakota, Nashington, and Wisconsin it is the responsibility of the County Textbook Selection Committee. In Viaryland it is the responsibility of the various county school superintendents.

All other states allow textbooks to be selected by the local governing board of education, selectmen, school directors, or other title given to the local governing board.

The length of time a single textbook may be used - varies from three years in Maryland, Rhode Island, Tennessee, and Washington to ten years in Montana. Most states have a 
minimum time of four years that books must be used before allowing a change.

Table XXI examines the statutory provisions of the 28 states prescribing a uniform series of textbooks with regard to the use of a multiple or singular adoption list and the manner in which books in these states are purchased. Twelve of the 28 states prescribing a uniform series of textbooks use a singular list. This means that only one book is prescribed for each grade or subject. The other states have multiple lists, that is, more than one book is given for each subject or grade. The states prescribing a single textbook list are: Alaska, Alabama, Connecticut, Hawai, Kansas, Louisiana, Nevada, North Carolina, South CaroIina, Utah, Virginia, and Wyoming. The other 16 states prescribe multiple listings.

By far the most common methoo of purchasing textbooks in these states is for school districts to purchase them directly from the publisher. In states having free textbooks, these are secured from the State Board of Education, which is generally responsible for their purchase and distribution.

\section{Applicable Court Decisions}

In the absence of any express authority, the Supreme Court of Montana held that the local school board had the right to select textbooks for their respective districts. 


\section{TABLE XXII}

STATUTORY PROVISIONS OF THE 28 STATES PRESCRIBING A UNIFORIV SERILS OF TEXTBOOKS

\begin{tabular}{|c|c|c|c|}
\hline State & $\begin{array}{l}\text { Multiple or } \\
\text { singular } \\
\text { lists }\end{array}$ & Purchased by & $\begin{array}{l}\text { Manner } \\
\text { of dis- } \\
\text { tribution }\end{array}$ \\
\hline $\begin{array}{l}\text { Alaska } \\
\text { Alabama } \\
\text { Arizona } \\
\text { Arkansas } \\
\text { California }\end{array}$ & $\begin{array}{l}\text { Singular } \\
\text { Singular } \\
\text { Multiple } \\
\text { Multiple } \\
\text { Multiple }\end{array}$ & $\begin{array}{l}\text { School District } \\
\text { Pupils } \\
\text { School District } \\
\text { State Board } \\
\text { State Board }\end{array}$ & $\begin{array}{l}\text { State Board } \\
\text { Free, } 1-8 \\
\text { Free, } 1-8 \\
\text { Free, } 1-8\end{array}$ \\
\hline $\begin{array}{l}\text { Connecticut } \\
\text { Delaware } \\
\text { Florida } \\
\text { Georgia } \\
\text { Hawaii }\end{array}$ & $\begin{array}{l}\text { Singular } \\
\text { Multiple } \\
\text { Multiple } \\
\text { Multiple } \\
\text { Singular }\end{array}$ & $\begin{array}{l}\text { Town Board } \\
\text { State Board-School } \\
\text { State Board } \\
\text { State Board } \\
\text { State Board }\end{array}$ & $\begin{array}{l}\text { Free, } 1-12 \\
\text { Free, } 1-12 \\
\text { Free, } 1-12 \\
\text { Rental system }\end{array}$ \\
\hline $\begin{array}{l}\text { Idaho } \\
\text { Indiana } \\
\text { Kansas } \\
\text { Kentucky } \\
\text { Louisiana }\end{array}$ & $\begin{array}{l}\text { Multiple } \\
\text { Multiple } \\
\text { Singular } \\
\text { Nultiple } \\
\text { Singular }\end{array}$ & $\begin{array}{l}\text { School District } \\
\text { School District } \\
\text { School District } \\
\text { State Board } \\
\text { State Board }\end{array}$ & $\begin{array}{l}\text { Niay be free } \\
\text { Rental } \\
\text { Free } \\
\text { Free }\end{array}$ \\
\hline $\begin{array}{l}\text { Mississippi } \\
\text { Nevada } \\
\text { New Mexico } \\
\text { North Carolina } \\
\text { Oklahoma }\end{array}$ & $\begin{array}{l}\text { Multiple } \\
\text { Singular } \\
\text { Multiple } \\
\text { Singular } \\
\text { Multiple }\end{array}$ & $\begin{array}{l}\text { State Board } \\
\text { School District } \\
\text { otate Board } \\
\text { State Board } \\
\text { School District }\end{array}$ & $\begin{array}{l}\text { Free } \\
\text { Free, 1-12 } \\
\text { Free, 1-8 } \\
\text { Free, 1-12 }\end{array}$ \\
\hline $\begin{array}{l}\text { Oregon } \\
\text { South Carolina } \\
\text { Tennessee }\end{array}$ & $\begin{array}{l}\text { Nultiple } \\
\text { Singular } \\
\text { Multiple }\end{array}$ & $\begin{array}{l}\text { School District } \\
\text { School District } \\
\text { County Superin- } \\
\text { tendent }\end{array}$ & $\begin{array}{l}\text { Free, } 1-8 \\
\text { Rental or free }\end{array}$ \\
\hline $\begin{array}{l}\text { Texas } \\
\text { Utah }\end{array}$ & $\begin{array}{l}\text { Nultiple } \\
\text { Singular }\end{array}$ & $\begin{array}{l}\text { State Board } \\
\text { State Superinten- } \\
\text { dent }\end{array}$ & Free \\
\hline $\begin{array}{l}\text { Virginia } \\
\text { West Virginia } \\
\text { Wyoming }\end{array}$ & $\begin{array}{l}\text { Singular } \\
\text { Multiple } \\
\text { Singular }\end{array}$ & $\begin{array}{ll}\text { School District } \\
\text { County Board } \\
\text { School District }\end{array}$ & $\begin{array}{l}\text { Free, } 1-8 \\
\text { May be free } \\
\text { Free, } 1-12\end{array}$ \\
\hline
\end{tabular}




\section{The Court stated:}

We are of the opinion that, under the circumstances and conditions of this case, the legislature having failed to provide a uniforil series of textbooks for use in the common schools of the state, and having failed to have special authority to any officer or board to do so, the trustees of the school districts of the state have the right, under the general powers vested in them by law, to provide a rule designating textbooks for use in the common schools of their districts.24

The courts also have held that in the absence of express statutory provisions, the teacher has the right to select and use a book he deems proper. 25

Where the worcs "uniform series" appear in the statutes, the question of whether or not the state textbook commission can adopt a split series or books from different authors and publishers arose in the Suprene Court of Kansas which ruled: 26

we construe the woras "uniform series" to mean the whole series adopted for use in the schools. Their use must be uniform in all schools of the grade where the particular book is used. The intent of the Legislature was not to provide a set of books on one subject necessarily by the same author. Where a series of readers has been adopted, it may be made up of books prepared by different authors. It is no less a uniform series of readers if the reader adopted for use in each

${ }^{24}$ Campana v. Calderhead et al., 17 Mont. 548, $44 \mathrm{P}$. 83, 36 A.L.R. 277 (1896).

25 State ex rel. Moore v. Millsap, 130 Mo. App. 683, 108 S.W. $1113(1908)$.

26 State ex rel Simon v. Fairchild et al., 87 Kan. 781,125 P. 40 (1912). 
grade is by a different author. 27

The commission or board given statutory power to select books can bind the state for a legal contract. They can select the books they think are suitable. 28

In a recent California case it was declared a violation of the Constitution when a budget law for uniform textbooks was passed forbidding the expenditure of funds for certain specific textbooks. The State Boara of Education adopted these and forced the Director of Finance to appropriate money for their printing. 29

When a uniforin series of textbooks has been adopted for use in a state, the courts have held uniformly that the statutory provisions for using them must be complied with. In 1899 a teacher in lennessee was fined $\$ 10.00$ for using a geography book different from the one adopted. 30 The word "basic" has been before the Supreme Court in Kansas in regard to the city of Lawrence which did not use stateadopted textbooks. The Court ruled:

It (the law) certainly does not authorize, in the slightest degree, the use of books other than those prescribed by the textbook commission ... The use of the word "basic" may be unfortunate and may have been

\section{Ibid.}

28 Smith et al. v. State Board of Control et al., 215 Cal. 421, $10 \mathrm{P}$. 2nd 736 (1932). (1959).

${ }^{29}$ State Board of Education v. Levit, 343 P. 2nd 8

30 Leeper v. State, 103 Tenn. 500, 53 S.W. 962, 48 L.R.A. 167 (1899). 
designed by the person who drafted the section as one for convenient exploitation for future purposes, but it is sufficient to say that a prohibition against excluding adopted books as "basic" books is no license to override the decisions of the textbook commission and avoid the law by naming adopted books "basic" and using others inore to the taste of the local board of education for the real purpose of instruction. 31

The Supreme Court in ilichigan ruled on the meaning of the leneth of adoption when a publishing company brought an action to enforce the placing of books in a school system contracted for a five-year period. The Court said:

We are of the opinion that the five years began to ruin from the date of the adoption of the resolution for the purchase ... and not from the time this arithmetic had been completely installed in all schools, in place of the others which it supplemented. "Books" are adopted when such actions as the statute provides are taken, and not when every other book then in use has been removed, and the new one substituted. 32

When a local board adopts a textbook, it automatically adopts the book selected by the state textbook commission, even though the edition date is not listed in the local board's adoption. 33

The records of the state board of education in regard to the free textbook fund are subject to audit like all

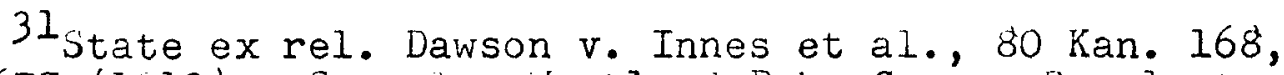
130 P. 677 (1913). See also Westland Pub. Co. v. Royal et al., 36 Wash. 399, 78 P. 1096 (1904); Wagner v. Royal et al., 78 P. 1094 (1904); Rand WCNally and Company v. Royal et al., 78 P. $1103(1904)$.

32 Attorney General ex rel. Wari et al. v. Board of Education of City of Detroic, D.C. Heath and Company v. Same, 133 Mich. 681, 95 N.W. 746 (i903).

33 Schloke v. Board oi Education of Ft. Thomas et al., $240 \mathrm{Ky} .426,42 \mathrm{~S}$. W. 2nd 526 (1931). 
other state funds. 34

The most recent rulings prohibit the use of public funds for free textbooks in church-related schools; however, the courts have not been consistent in this regard. 35

\section{THE TRANSPORTHAON OF PUPIES}

The transortation of school pupils to and from school has becone a problem of major concern to school officials within recent years. This is due to a number of reasons: the increase in flow of traffic over the nation's roacs, the siniting of the nation's population to suburban areas, and the consolidation of smaller school districts into larger units of central adininistration. As a result, state legislatures have imposed increased restrictions on the operation of school vehicles. Increased safety regulations jertaining to the operation and inspection of school vehicles are now in effect in most states. The financial aspects of the adininistration of pupil transportation also have concerned legislatures and other state authorities; thus, in a considerable numoer of states,

${ }^{34}$ Stata ex rel. Prohmiller v. Hendrix, 56 Ariz. 342, 107 P. 2nd 1078 (1940).

35 Dicrman v. School District ivo. 62C, Oregon City, 223 Or. 347, 366 P. 2nd 533 (1961); Chance et al. v. Mississippi state l'extbook Rating and Purchasing Board et al., 190 iriss. 453, 200 So. 706 (1941); Cochran et al. v. Louisiana State Board of Sducation et 21., $168 \mathrm{La} .1030,123$ So. 664,281 U.S. 370 (1930); Borden et al. v. Louisiana State Board of Education et al., 16́s La. 1005, 123 So. 655 (1929). 
financial controls have been written to govern local pupil transportation.

Pupil transportation is conducted by school districts of the states generally by three methous: district-owned and -operated vehicles, through the use of common commercial carriers, and through contract arrangenents with private concerns or individuals. The state legislatures have enacted statutory provisions requiring manciatory compliance in a number of different areas related to the transportation of pupils by one of the three methods.

Bolmeier ${ }^{36}$ recently discussed "Trends in Pupil Transportation Litigation" in The American School Board Journal. He states:

Transportation laws which are inost mandatory on the part of local school boards of education are those in which the state board of education is authorized by law to specify, within constitutional and legislative limitations, the regulations under which transportation is to be provided. In at least five states (Delaware, Minnesota, ivw hico, New Jersey, and North Carolina), the state Doarcis are so empowered. il though much of authority may be discretionary for the state board of education, it is usually mandatory for the local boards. Any regulations which the local ooard of education may specify must conform to those of the state board of education. 37

Table XXII presents a detailed analysis of the statutory provisions regarding the transportation of pupils that

36. C. Bolmeier, "Trencis in Pupil Transportation Litigation," The American School Board Journal, CXI (February, $1960 \%, 39$.

37 Ibid. 
commonly require state agency approval.

Fourteen states require state agency approval of school bus routes: Idaho, Iowa, Michigan, Mississippi, New Mexico, New York, Oklahoma, Pennsylvania, Rhode Island, South Carolina, Tennessee, Texas, Washington, and Wisconsin. In New Vlexico and Washington this responsibility is performed by the State Transportation Commissioner, while in all the other states just listed the responsibility is placed with the state educational authorities. In New York state approval of transportation routes is required only in certain class districts.

In California, Kansas, North Carolina, and Nyoming the school bus routes are approved by county superintendents of schools in at least part of the school districts.

State asency approval of contracts with outside individuals is reyuired in Idaho, Kentucky, lississippi, Montana, New Mexico, New York, North Carolina, Penzylvania, Rhode Island, and Wisconsin. The State Division of Transportation and the State Transportation Coramissioner have this responsibility in New Hexico and Washington, respectively. In ail the other states listed above, it is the responsibility of the State Board of Education or of the chief state school officer or his departnent. In New Jersey the county superintendents must approve contracts.

The statutes in Alaska, Connecticut, Vassachusetts, Nevada, New Hampshire, South Dakota, and Utah do not 


\section{TABLE XXIII}

STATUTORY PROVISIONS GOVERING THE TRANSPORTATION OF PUPILS

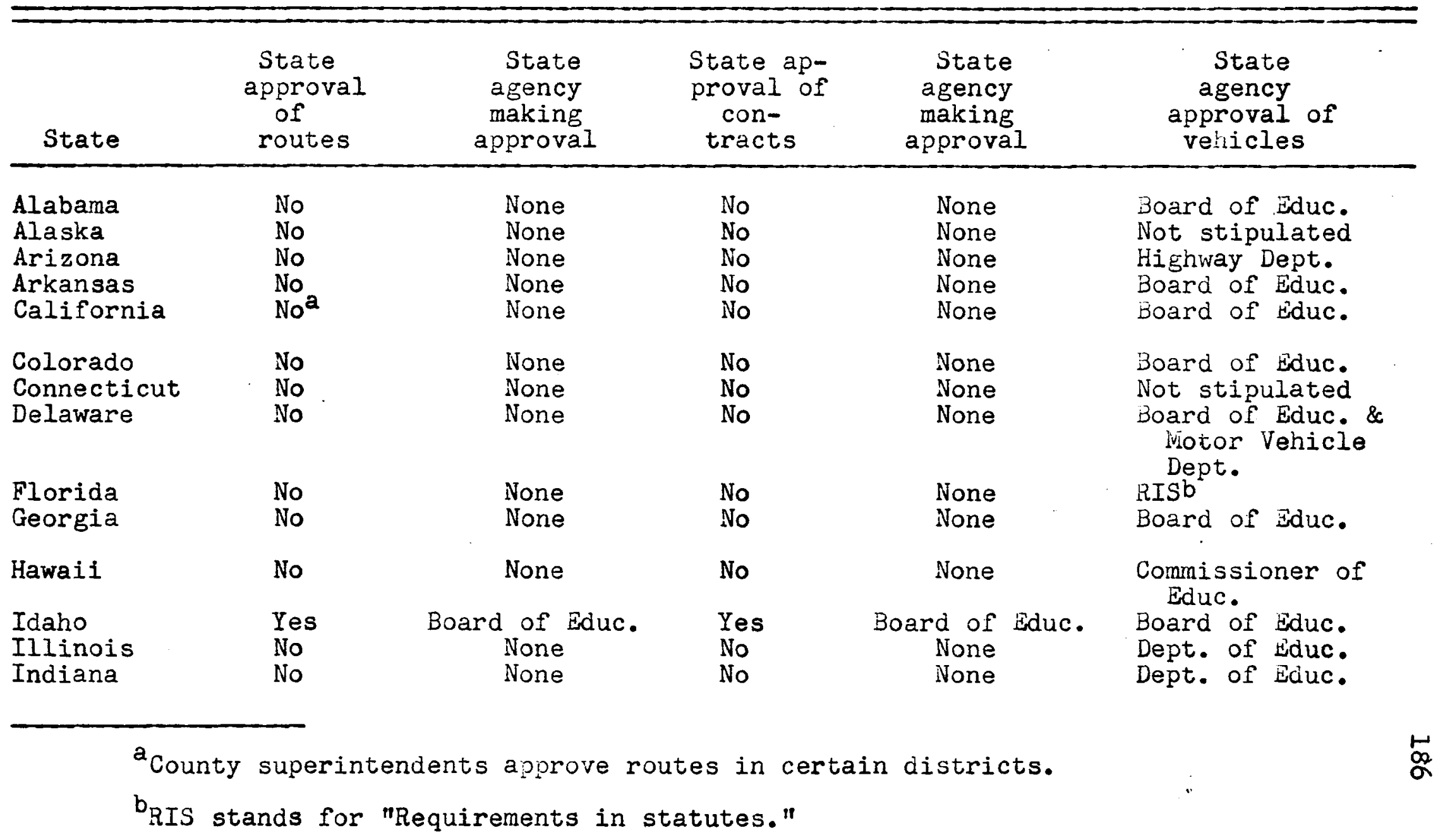


TABLE XXIII (cont.)

\begin{tabular}{|c|c|c|c|c|c|}
\hline State & $\begin{array}{l}\text { State } \\
\text { approval } \\
\text { of } \\
\text { routes }\end{array}$ & $\begin{array}{c}\text { State } \\
\text { agency } \\
\text { making } \\
\text { approval }\end{array}$ & $\begin{array}{l}\text { State ap- } \\
\text { proval of } \\
\text { con- } \\
\text { tracts }\end{array}$ & $\begin{array}{c}\text { State } \\
\text { agency } \\
\text { making } \\
\text { approval }\end{array}$ & $\begin{array}{l}\text { State } \\
\text { agency } \\
\text { approval of } \\
\text { vehicles }\end{array}$ \\
\hline $\begin{array}{l}\text { Iowa } \\
\text { Kansas } \\
\text { Kentucky } \\
\text { Louisiana } \\
\text { Maine }\end{array}$ & $\begin{array}{l}\text { Yes } \\
\text { Noc } \\
\text { No } \\
\text { No } \\
\text { No }\end{array}$ & $\begin{array}{l}\text { Dept. of Bduc. } \\
\text { None } \\
\text { None } \\
\text { None } \\
\text { None }\end{array}$ & $\begin{array}{l}\text { No } \\
\text { No } \\
\text { Yes } \\
\text { No } \\
\text { No }\end{array}$ & $\begin{array}{l}\text { None } \\
\text { None } \\
\text { board of Educ. } \\
\text { None } \\
\text { None }\end{array}$ & $\begin{array}{l}\text { Dept. of Educ. } \\
\text { Highway Commission } \\
\text { Board of Educ. } \\
\text { Board of Educ. } \\
\text { Board of Educ. }\end{array}$ \\
\hline $\begin{array}{l}\text { Maryland } \\
\text { Massachusetts } \\
\text { Michigan } \\
\text { Minnesota } \\
\text { Mississippi }\end{array}$ & $\begin{array}{l}\text { No } \\
\text { No } \\
\text { Yes } \\
\text { No } \\
\text { Yes }\end{array}$ & $\begin{array}{l}\text { None } \\
\text { None } \\
\text { Board of Educ. } \\
\text { None } \\
\text { Board of Educ. }\end{array}$ & $\begin{array}{l}\text { No } \\
\text { No } \\
\text { No } \\
\text { No } \\
\text { Yes }\end{array}$ & $\begin{array}{l}\text { None } \\
\text { None } \\
\text { None } \\
\text { None } \\
\text { Board of Educ. }\end{array}$ & $\begin{array}{l}\text { RIS } \\
\text { Not stipulated } \\
\text { Board of Educ. } \\
\text { RIS } \\
\text { Board of Educ. }\end{array}$ \\
\hline $\begin{array}{l}\text { Missouri } \\
\text { Nontana } \\
\text { Nebraska } \\
\text { Nevada } \\
\text { New Hampshire }\end{array}$ & $\begin{array}{l}\text { No } \\
\text { No } \\
\text { No } \\
\text { No } \\
\text { No }\end{array}$ & $\begin{array}{l}\text { None } \\
\text { None } \\
\text { None } \\
\text { None } \\
\text { None }\end{array}$ & $\begin{array}{l}\text { No } \\
\text { Yes } \\
\text { No } \\
\text { No } \\
\text { No }\end{array}$ & $\begin{array}{l}\text { None } \\
\text { Superintendent } \\
\text { None } \\
\text { None } \\
\text { None }\end{array}$ & $\begin{array}{l}\text { County Supt. } \\
\text { Superintendent } \\
\text { safety Patrol } \\
\text { Not stipulated } \\
\text { Not stipulated }\end{array}$ \\
\hline $\begin{array}{l}\text { New Jersey } \\
\text { New Mexico } \\
\text { New York }\end{array}$ & $\begin{array}{l}\text { No } \\
\text { Yes } \\
\text { Yes } d\end{array}$ & $\begin{array}{l}\text { None } \\
\text { Division of Trans- } \\
\text { portation } \\
\text { Commissioner of } \\
\text { Educ. }\end{array}$ & $\begin{array}{r}\text { Noc } \\
\text { - Yes } \\
\text { Yes }\end{array}$ & $\begin{array}{l}\text { None } \\
\text { Division of } \\
\text { Transportation } \\
\text { Commissioner of } \\
\text { Educ. }\end{array}$ & $\begin{array}{l}\text { RIS } \\
\text { Division of } \\
\text { Transportation } \\
\text { Public jervice \& } \\
\text { Wotor Vehicle } \\
\text { Dept. }\end{array}$ \\
\hline
\end{tabular}

${ }^{c}$ Approval of the county school superintendent required.

$\mathrm{d}_{\text {Certain districts only }}$ 
TABLE XXIII (cont.)

\begin{tabular}{|c|c|c|c|c|c|}
\hline State & $\begin{array}{l}\text { State } \\
\text { approval } \\
\text { of } \\
\text { routes }\end{array}$ & $\begin{array}{c}\text { State } \\
\text { agency } \\
\text { making } \\
\text { approval }\end{array}$ & $\begin{array}{l}\text { State ap- } \\
\text { proval of } \\
\text { con- } \\
\text { tracts }\end{array}$ & $\begin{array}{c}\text { State } \\
\text { agency } \\
\text { making } \\
\text { approval }\end{array}$ & $\begin{array}{l}\text { State } \\
\text { agency } \\
\text { approval of } \\
\text { vehicles }\end{array}$ \\
\hline $\begin{array}{l}\text { North Carolina } \\
\text { North Dakota } \\
\text { Ohio } \\
\text { Oklahoma } \\
\text { Oregon }\end{array}$ & $\begin{array}{l}\text { No } \\
\text { No } \\
\text { No } \\
\text { Yes } \\
\text { No }\end{array}$ & $\begin{array}{c}\text { None } \\
\text { None } \\
\text { None } \\
\text { Board of Educ. } \\
\text { INone }\end{array}$ & $\begin{array}{l}\text { Yes } \\
\text { No } \\
\text { No } \\
\text { No } \\
\text { No }\end{array}$ & $\begin{array}{l}\text { Board of Educ. } \\
\text { None } \\
\text { None } \\
\text { None } \\
\text { None }\end{array}$ & $\begin{array}{l}\text { Board of Educ. } \\
\text { Superinterident } \\
\text { Board of Educ. } \\
\text { Board of Educ. } \\
\text { Board of Educ. }\end{array}$ \\
\hline $\begin{array}{l}\text { Pennsylvania } \\
\text { Rhode Island }\end{array}$ & $\begin{array}{l}\text { Yes } \\
\text { Yes }\end{array}$ & $\begin{array}{l}\text { Dept. of Iduc. } \\
\text { Commissioner of } \\
\text { Educ. }\end{array}$ & $\begin{array}{l}\text { Yes } \\
\text { Yes }\end{array}$ & $\begin{array}{l}\text { Dept. of Educ. } \\
\text { Commissioner of } \\
\text { Educ. }\end{array}$ & $\begin{array}{l}\text { Dept. of iduc. } \\
\text { Board of Iduc. }\end{array}$ \\
\hline $\begin{array}{l}\text { South Carolina } \\
\text { South Dakota } \\
\text { Tennessee }\end{array}$ & $\begin{array}{l}\text { Yes } \\
\text { No } \\
\text { Yes }\end{array}$ & $\begin{array}{l}\text { Superintendent } \\
\text { None } \\
\text { Commissioner of } \\
\text { Educ. }\end{array}$ & $\begin{array}{l}\text { No } \\
\text { No } \\
\text { No }\end{array}$ & $\begin{array}{l}\text { None } \\
\text { None } \\
\text { None }\end{array}$ & $\begin{array}{l}\text { Hignway Cominission } \\
\text { Not stipulated } \\
\text { Board of Educ. }\end{array}$ \\
\hline Testas & Yes & $\begin{array}{l}\text { Commissioner of } \\
\text { Educ. }\end{array}$ & No & None & Board of Educ. \\
\hline $\begin{array}{l}\text { Utah } \\
\text { Vermont }\end{array}$ & $\begin{array}{l}\text { No } \\
\text { No }\end{array}$ & $\begin{array}{l}\text { None } \\
\text { None }\end{array}$ & $\begin{array}{l}\text { No } \\
\text { No }\end{array}$ & $\begin{array}{l}\text { None } \\
\text { None }\end{array}$ & $\begin{array}{l}\text { Not stipulated } \\
\text { Commissioner of } \\
\text { Educ. }\end{array}$ \\
\hline $\begin{array}{l}\text { Virginia } \\
\text { Washington }\end{array}$ & $\begin{array}{l}\text { No } \\
\text { Yes }\end{array}$ & $\begin{array}{c}\text { None } \\
\text { Transportation } \\
\text { Cornmission }\end{array}$ & $\begin{array}{l}\text { No } \\
\text { No }\end{array}$ & $\begin{array}{l}\text { None } \\
\text { None }\end{array}$ & $\begin{array}{l}\text { Board of iduc. } \\
\text { Transportation } \\
\text { Commission }\end{array}$ \\
\hline
\end{tabular}

${ }^{e}$ City and county superintendents approve in appropriate districts. 


\section{TABLE XXIII (cont.)}

\begin{tabular}{|c|c|c|c|c|c|}
\hline State & $\begin{array}{l}\text { State } \\
\text { approval } \\
\text { of } \\
\text { routes }\end{array}$ & $\begin{array}{c}\text { State } \\
\text { agency } \\
\text { making } \\
\text { approval }\end{array}$ & $\begin{array}{l}\text { State ap- } \\
\text { proval of } \\
\text { con- } \\
\text { tracts }\end{array}$ & $\begin{array}{c}\text { State } \\
\text { agency } \\
\text { making } \\
\text { approval }\end{array}$ & $\begin{array}{l}\text { State } \\
\text { agency } \\
\text { approval of } \\
\text { vehicles }\end{array}$ \\
\hline $\begin{array}{l}\text { West Virginia } \\
\text { Wisconsin } \\
\text { Wyoming }\end{array}$ & $\begin{array}{l}\text { No } \\
\text { Yes } \\
\text { Nof }\end{array}$ & $\begin{array}{c}\text { None } \\
\text { Superintencient } \\
\text { None }\end{array}$ & $\begin{array}{l}\text { No } \\
\text { Yes } \\
\text { No }\end{array}$ & $\begin{array}{l}\text { ivone } \\
\text { Superintendent } \\
\text { None }\end{array}$ & $\begin{array}{l}\text { Board of Educ. } \\
\text { Superintendent } \\
\text { Board of Educ. }\end{array}$ \\
\hline
\end{tabular}

$f_{\text {Approval of routes by county sciool superintendents. }}$ 
stipulate the agency responsible for the approval of transportation vehicles. In Florida, Minnesota, and New Jersey the requirements for school vehicles are printed in the statute books and are to be enforced by the respective state boards of education.

In Arizona, Delaware, Kansas, Nebraska, New Wiexico, New York, South Carolina, and Wasnington, regulations are set up by the state law enforcement bureau, the motor vehicle departinent, or the state transportation department. The requirements for vehicle specifications in the other states are the responsibility of the state board of education or of the chief state school officer and his department. In Missouri the vehicles must be approved by the county superintendents of schools.

Applicable Court Decisions

Court decisions relative to transportation routes have been litigated over the "distances" involved. Even in states where statutory provisions are expressly detailed in the number of miles students may walk, the courts have defined board rules as reasonable in many cases.

In State ex rel. Rice v. Tompkins et al., $38^{\circ}$ a case in

${ }^{38}$ State ex rel. Rice v. Tompkins et al., 239 ivio. App. 1113, 203 S.W. 2nd 881 (1947). See also Flowers v. Independent School District of Tama et al., 235 Iowa $332,16 \mathrm{~N}$. W. 2nd 570 (1944); State ex rel. Brand v. Mostad, 28 N.D. 244, 148 N.W. 831 (1914); Lyle v. State ex rel. Smith, 172 Ind. 502, 88 N.E. 850 (1909); State ex rel. Stewart et al. v. 
Missouri where transportation has to be voted on by the residents of the district, the court said the school board did not abuse its discretion when a child was picked up two miles from his home in bad weather and three-eighths of a mile in good weather. The court said:

Under our statutes the only office mandamus can perform, as to transportation of children to and from school, is to require the school directors, where transportation has been voted, to exercise their discretion in providing such transportation in accordance with reasonable rules and regulations which they may adopt therefor .... Where no fraud or corruption or abuse of discretion is alleged or shown on the part of the members of the school board, the courts are not justified in inquiring into their motives, provided their action is otherwise lesally justifiable. 39

Contracts with individuals must be written contracts, with a "neeting of the mincs" of the school board and the individual subnitting the contract. 40

The Board of igg Harbor Township appealed a State Board of Gducation ruling that a contract was made illegally when the Board enlarged upon the rules of the state Board of Education regarding competitive bidding of transportation contracts. The court held:

We disagree with appeliants that the Local Board had the power to enlarge any rule, regulation or

\section{8 (cont.)}

Miller, 193 Ind. 492, 141 N. .. 60 (1923); Walters v. State, 212 Wis. 132,248 N.W. 777 (1933).

${ }^{39}$ Staic ex rel. Rice v. Tompkins et al., supra.

40 jiarshall v. Board of Directors ivacedonia Sciool

District et al., $200^{\circ}$ Ark. 346, 186 S.W. 2nd 149 (1945);

Lucier v. Town of Norfolk, 99 Conn. 686, 122 A. 711 (1923). 
specification imposed by the State Board. It is the prerogative of Local Board to contract for the needed facilities of pupil transjortation, but its contracts are subject to the supervision of the jtate Board uncier the statutes cited and must be awarded in conformity with the poligy underlying the law to encourase competitive biciding. 41

The local Board required the buses to be present when the contracts were awarded. The plaintiff could not do so, even though he was the low bidder. As a result, the Board gave the bid to a higher bidder who was a relative of a Board member.

\section{SUMMARY}

In the auxiliary areas of school operation considered in this chapter, state concern for financial management can be observed. Lagislatures have been interested in protecting financial as well as other public interests in operating these phases of the school program in the local districts. They have sought to protect these interests both by statutory provisions and by requiring specified state agencies to approve local decisions and practices in the conduct of these school activities.

1. Statutory provisions governing student activity accounts are found only in a minority of the states. Those states having such provisions usually require aciequate and

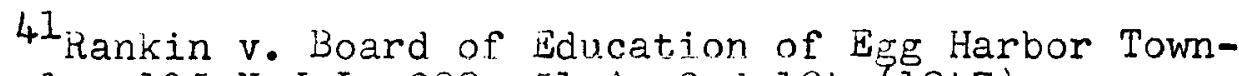
ship et al., 135 N.J.L. 299, 51 A. 2nd 194 (1947). 
accurate records and the conduct of an annual audit of student fund accounts.

2. All the states have statutory provisions perinittin school districts to operate and manage school Iunchrooms or cafeterias. Of all of the areas covered in this study, the operation and maintenance of the school lunchroom is the most uniform. It nay be presumed that this is the result of the use of recomnended statutes as required by the National School Lunch ict. All states participate in this Act, and the basic requirements established by the Secretary of igriculture must be complied with. These are administered through "state plans." Variations in the provisions of state plans are found anong the states, but plans apply uniformly to school districts within each state.

3. Hany states have enacted statutes to govern the administration of school textiooks. The objectives here are (a) honest and economical financial managenent in obtaining and using textbooks, and (b) the control of the school curriculum. The present study is concerned only with the first of these. Financial control is exercised through (a) state selection of single or multiple lists, and sometimes the purchase of textbooks, or (b) statutory or other state regulations governing actions of local school officials in selecting, purchasing, and using textbooks.

4. The states have imposed statutory provisions over the operation of vehicles used in the transportation of 
pupils. The financial aspects of pupil transportation have been of major concern to state legislatures, particularly where state funcis are used to support pupil transyortation programs. The most common provisions enacted cieal with the approval of bus routes, the apjroval of "transportation contracts" between parties, and the approval of vehicles used in transportating pupils to insure minimum safety standards. These iterns may be subject to state ajency approval in order to insure efficient and proper expenditure of state funds. Slightly under one-half of the states require the approval of bus routes by a state agency. The state bourd of education is by far the agency most frequently specified to approve proposed bus routes and contracts, as well as the agency specified to prescribe regulations and approval of vehicles. 


\section{CHAPTIR VII}

\section{SUMULARY AND CONCLUSIONS}

Public education is a function of the state governments in all of the states. The responsibility for providing a system of public education is one for the legislature in each of the states. The state legislatures are free to designate whatever agencies they see fit to administer public education and, in fact, the administrative structure for operatin the public schools differs significantly from one state to another.

The administrative controls of public education in the various states are diverse and sometimes widely dispersed. The control of fiscal policy in the administration of public schools in each of the 50 states is regarded as a matter of great public importance. Social, economic, and political aspects of life in contemporary society are very complex, and the provisions for operating schools under these conditions are necessarily extensive and detailed in order to deal effectively with the proolems of school operation. The several states have shown great concern for the management of fiscal affairs in local school districts. Legislatures in the various states have imposed very considerable restrictions upon the financial management of local 
school systems. These controls are exercised in two ways: (1) through detailed statutory provisions, and (2) through a divided control over local school district financial affairs exercised by school officials and by the various other agencies of government.

\section{SCOPE OF : THI STUDY}

Specific attention is given in the present study to the distribution of power to control the financial administration of education at the local level. An examination has been undertaken of the scope of state controls exercised by the 50 states over the operation of local school district financial matters. Three major questions have been considered:

1. What are the actual controls exercisad by state agencies over the operation of local school district financial affairs?

2. How have the courts interpreted these controls where conflict between local and state agencies has resulted in litigation?

3. What generalizations can be drawn fron the statutes, rules anci regulations of state a gencies and from court decisions relating to them?

The data collected and analyzed in this study have been presented with a consideration of the above questions.

\section{PROCEDURES OF RESEARCH}

The procedures of documentary analysis have been employed in conducting this study. The legal codes of the 
individual states have been examined for applicable statutory provisions. The rules and regulations of state agencies were reviered for authoritative provisions. Court decisions were rejorted for the specific topic under consideration where relevant to the material in question. In order to clarify special problems being considered, selected secondary sources were used widely. Legal treatises were examined where relevant to the problem being considered.

\section{GEINRAL CUNCLUSIUNS}

Certain general conclusions can be drawn from an analysis of the data collected and reported in the present investigation.

1. The control of local school district financial policy is exercised by each of the various states through specific statutory provisions which are applicable to local financial policy and within which the local school districts must operate, and through regulation, supervision, inspection, and approval powers exercised by various state agencies over local school district financial operations. The patterns in use in the various states are exceedingly diverse, and responsibility for financial matters is widely distributed. However, the controls exercised from the state level on local school districts are extensive and important in each of the states.

2. The classification of school districts in many 
of the states has a significant effect upon the operation of state policy in financial management. Many provisions in individual states apply only to certain classes or categories of school districts. Thus some caution neecis to be exercised by local and state officials in considering how individual statutes affect school operation in an individual state, and interpretations such as those in the present report are subject to the same Limitation.

3. There is some evidence to indicate that state controls are imposed on local school districts in part as an operation of a system of "checks and balances." However, it appears that other factors also influence the legislatures in designing state controls. Among these are the matter of convenience, use of tile talents of personnel professionally trained in financial management, and the creation of compatible working relationships between already-existing departments of government. It appears that some allocations of responsibility are the result of continuing legislative policy under which certain aencies nay already have been designated to perform particular types of fovernmental services. In such cases the legislatures appear merely to have extended these policies anc allocations to inclucie the public schools.

4. The data presented in this study support the commonly-recognized generalization that where statutory provisions are specific, school officials are required to follow 
them. When confiicts between state agencies and local school officials over statutory interpretations have resulted in litigation, statutory provisions have been given a "liberal interpretation" by the courts in favor of the greatest educational advantage consistent with sound fiscal policy and respect for constituted governinental authority. If statutory provisions are substantially complied with, the courts are likely to uphold the discretion of local school boards.

5. It is a matter of cominon knowledge that state participation in the financial support of local school operation has been increased in recent years, and it appears that the same trend is continuing. Fron the close association between state finance plans and the provisions for state supervision of local school district financial operation in many of the states, it would appear that the increase in state financing is often accompanied by increased state control. The problem of naintaining an effective working relationship among the various agencies participating in the financial management of schools, thus, becomes an inportant and continuing one. 


\section{SELECTED BIBLIOGRAPHY}




\title{
SELECTED BIBLIOGRAPHY
}

\author{
BOOKS
}

American Association of School Administrators. School District Organization Yearbook. Washington: Arnerican Association of School Administrators, 1958.

Association of School Business Oificials of the United States and Canada. Annual Jolume of Proceedings. Dvanston: Association of school Business Jfficials, 1961.

Benson, Charles 3. The Economics of Public Álucation. Cambridge: The Riverside Press, 1ybl.

Black, Henry C. Black's Law Dictionary. ut. Paul: ivest Publishing Company, 1951 .

Burke, Arvid J. Lefensible Spencing for Public Schools. iNew York: Columbia University $\operatorname{Pr} e s i s, 1943$.

Burr, Samuel Engle Jr., R. Aerle Eyman, and Wylie H. Russell. The Develoment of Fiscal Relationships of State Departidents of Education. vashincton: United States Office of Lducation, 1,60 .

Burrup, Percy E. Hodern High Jchool Adininistration. New York: Harper and Brothers, Publishers, 1962.

Butterworti, Julian Idward. Problems in State High school Finance. New York: World Book Company, 1918.

Campbell, Ronald F., John é. Corbally, and John Ȧ. Ramseyer. Introduction to iducational duministration. Boston: Allyn and Bacon, Inc., 1958 .

Cooperative Program in Ediucational Administration. Educational Consultants and Their Work in Widwestern State Departments of iducation. Chicago: The University of Chicago Press, 1952.

Committee on Sducational Pinance. Financing Education for Uur Changing Population. Washington: National Education Association, 1961. 
Cubberley, Ellwood P. Public Education in the United states. Cambridge: The Riverside Press, 1947. - - School $\frac{\text { Funds }}{\text { Bureau }}$ af Publications, $\frac{\text { Their }}{1927 .}$. Nionment. Fork:

Drury, Robert L. (ed.). Law and the jchool superintendent. Cincinnati: The i. H. Anderson Company, 1958.

Edwards, Newton. The Courts and the Public jchools. Revised edition. Chicago: The University of Chicago Press, 1955.

Englehardt, iv. L., and Fred ingleharcit. Public
ness Administration. New York: Bureau OP Publications, 1927.

Frasier, Geore $W$ The Control of City School Finances. Milwaukee: The Bruce Publisinin Company, 1922.

Gibbs, Janes $I_{.}$, Robert F. Vill, and Louise R. Wurphy State School Administration 1900-1957. Washington: United States Government Printing office, 1960.

Garber, Lee 0. (ed.). Law and the School Business Manager. Danville: Tile Interstate Printers and Publishers, Inc., 1957.

Garber, Lee 0. Yearbook of School Law. Danville: The Interstate Printers and Publishers, Inc., 1950-1962.

Groves, Harold H. Viewpoints on Public Finance. ivew York: Henry Holt and Company, 1948.

Hales, Dawson. Federal Control of Public uducation. New York: Bureau of Publications, 1954 .

Hamilton, Robert R., and Paul R. iort. The Law and Public Education. Brooklyn: The Foundation Press, Inc., 1959.

Hamilton, Robert R., and Idmund Reutter, Jr. Legal ispects of school 3oard Operation. New York: Bureau of PubIications, 1958.

Henry, Nelson B., and Jerone G. Kerwin. jchools and City Government. Chicago: The University of Chicago Press, 1938.

James, H. Thomas. jchool Revenue jystems in Five States. Washington: United States Office of tucation, 1961. 
Johns, R.L., and E.L. Viorphet (eds.). Problems and Issues in jchool Finance. New York: Bureau of Publications, 1952 .

Johns, Roe L., and Edgar L. Morphet. Financing the Public Schools. Englewod Cliffs: Prentice-Hall, Inc., 1960 .

Knezevich, Stephen J., anc John Guy Fowlkes. Business vianagernent of Local School Systems. ivew York: Harper ana Brothers, 1960 .

Lawson, Douglass 2. pchool Administration procedures and Policies. ivew York: The Odessy Press, 1953.

Linn, Henry H. School Business idministration. New York: The Rionald Press Company, 1956. McGaughy, J.R. Fiscal $\frac{\text { Administration }}{\text { New York: The }}$ Tacmilian Company, $\frac{\text { City }}{1924}$.

Viller, Van, and villard B. Spaulding. The Public Administration of sumerican schools. Second edition. New York: Wor ld Book Conjany, I958.

Moehlman, Arthur E. ichool Administration. Second edition. New York: Houghton Wifflin Company, 1y5l.

Morphet, Edjar L., Roe L. Johns, and Theodore L. Reller. Educational idministration. inglewood Cliffs: Prentice-Hall, Inc., 1959.

Mort, Paul R. Principles of uchool Administration. New York: McGraw-Hill Book Company, 1946.

- State juport for Public Bducation. Washington: The American Council on Liducation, 1933.

Mort, Paul R., Nalter C. Reusser, and John if. Polley. Public jchool Finance. Thira edition. New York: incGraw-Hill Book CompanJ, 1960.

Munse, ilbert R. Revenue Programs for the Public Schools in the United States: 1959-60. Washinton: United States Jffice of Education, 1961.

Murphy, Irvin P. A Report to the Legislature. Santa Fe: 1961.

National Committee on School Health Policies. Suggested School Health Policies. Washington: National Education Association, 1956. 
Ovsiew, Leon, and William Castetter. Budgeting for Better Schools. Englewood Cliffs: Prentice-Hall, Inc., 1960.

Punke, Howard H. The Courts and Public jchool Property.

Chicaro: The University of Chicago Press, 1y36.

Putnain, Charlton 3. How to Find the Law. St. Paul: West Publishing Company, $\overline{1949 .}$

Reason, Paul L., and Alpheus L. White. Financial Accounting for Local and State School Systerns. Washington: Government Printing Jf fice, 1960.

Reeder, Ward G. The Fundamentals of Public School Administration. Fourth edition. TNew York: The lilacmillan Company, 1953 .

Remmlein, Vaduline rinter. The Law of Public School Administration. New York: lic Graw-HiIl Book Company, 1953.

Remmlein, Wadaline Kinter, and Warthä L. vare. An Svalustion of Existing Forms of School Law. Cincinnati: The N.H. Lnclerson Comivany, 1959.

Rosentengel, Nilliam Everett, anù Jefferson N. Zastmond. School Finance. "ew York: The Ronald Press Company, 1957.

Schloss, Samuel, Carol Joy Hobson, and Einery i.. Poster. Statistics of State ìchool jystens: 1y57-58. Washington: Governnent Printing Office, 1961.

Sears, Jesse B. City School Administrative Controls. Hew York: McGraw-Hill Book Company, 1933.

Seitz, Reynolds C. (ed.) Law and the School Principal. Cincinnati: The W.H. Anderson Company, 1961.

Soper, Wayne w. Legal Linitations on the Rights and Powers of School Boards with Respect to Taxation. New York: Bureal of Publications, 1929.

Spurlock, Clark. Education and the Suprene Court. Urbana: The University of Illinois Press, 1955.

Strajer, George D., Jr. Centralizing Tendencies in the Administration of Public jducation. New York: Bureau of Publications, 1934 . 
Swift, Fletcher Harper. Federal and State Policies in Public School Finance in the United States. New York: Ginn and Company, 1 y31.

- Studies in Public School Finance. viinneapolis: The University of ivinnesota Press, lyz2.

Thurston, Lee $\psi_{1}$, and Nilliam H. Roe. State School Administration. New York: Harper anci Brothers, 1957.

Trusler, Harry Raymond. Lissentials of jchool Law. Milwaukee: The Bruce Publishing Company, 1927 .

Weltzin, Joachim Fredrick. Lesal Authority of the American Public jchool. Grand Forks: The Hidwest Book Concern, 1931 .

\section{ARTICLAS IN PARIOLICALS}

Baughman, Morris F. "Beware False Equalization," The American School Boarc Journal, CXL (June, 1960).

Bolmeier, E.C. Wunicipal Participation in City School Finance," The Ainerican School Board Journal, XCVII (August, 1938 ).

Mitunicipal Participation in the Control of City School Property," The American jchool Board Journal, CXVII (September, $\overline{193}$ ).

"Trencis in Pupil Transportation Litigation," The American jchool Board Journal, CXL (February, 1960).

Burke, Arvid J. "Improvement in Educational quality," The School Executive, LXXIX (Noveinier, 1y5y).

Chambers, J.L. "Public School Auditing Practices in the United States," The American School Board Journal, XXCV (Septenber, $\overline{1932}$ ).

Chisholm, Leslie L. "roney for the Schools--liow to Advise State Legislators," Phi Lelta Kappan, XLII (October, $1960)$.

Cocking, Nalter D. "Can We Adequately Finance Our Schools," The school Executive, LXXVII (October, 1957).

Davis, Donald P. "Legal Requirenents in School Indebtedness and Proposed Legislation," The American School Board Journal, XCVI (February, 1930). 
Edwards, Newton. "Authority Over Education is Shifting Toward the Central Government," The Nation's Schools, LVIII (October, 1956).

Eggert, Walter A. "Short Tern Borrowing for School Purposes," The American School Board Journal, XCIX (December, $\overline { 1 9 3 } y \longdiv { \text { . } }$

Englehardt, N.L. "The School Budget as an Adininistrative Control," The School Executive, LXVII (Novenber, 1947).

Fowlkes, John Guy. "school Policies and the Budget," The School Executive, LXVII (November, 1947).

Johns, R.L. "State Services on Financial Problems," The School Executive, LXIII (July, 1947).

Lindman, Erich L. "How to Improve the Local and itate School Tax Structure," The imerican School Board Journal, CXL (ivay, 1960).

McCann, Lloyd E. "uanagin" Student ictivicies Funas," The American jchool board Journal, LV (June, 1955).

Norphet, Edgar L. "Auditing Services; there the ine Should Be Drawn," The Nation's Jchools, xXII (July, 1933).

"Improvin Procedures for Auditing Jchool Accounts," Educational Administration and Supervision, XXIV (Septenber, 1938).

"Service v. Control in Auditing," The Nation's Schools, XXI (June, 1933).

Mort, Paul R. "Voter Control vs. Boaru Control of budigets," The school Executive, LXVIII (July, 1Y51).

Roach, Stephen F. "Conflicts Between School Districts and Municipalities," The American School Board Journal, CXXLIX (July, 1959).

"Compliance with inicipal Codes," The American School Board Journal, CXXLIX (September, 1959).

"Liberal Court Interpretations of School Statutes," The American School Board Journal, CXXiviII (April, 1949).

Rosenstengel, W. . "The Annual Financial fudit," The Anerican School Board Journal, CII (itay, 1941). 
Flint, Jack Wetzler. "Some Suggestions for the Implementation of the ivissouri Public School Audit Law." Unpublished Doctor of Education dissertation, University of ilissouri, Columbia, 1957.

Huls, Harry E. "itate Limitations on Local Public school Expenditures in the United States." Unpublished Doctor of Philosophy dissertation, University of Minnesota, innea, 01 is, 1958.

Micann, Lloyd I. "The Classification of Local School Districts in Nebraska." Unpublished Doctor of Education field study, Coloracio State College of Education, Greeley, 1951.

Miller, Ernest Gale. "Financing Public iducation in the United States: The Problem of Fiscal Support and Intergovernmental Relations." Unpublished Doctor of Philosophy dissertation, Princeton University, Princeton, 1959. 
A P PENDIX 


\section{APPENDIX: TABLE OF CASES CITED}

\section{Case}

$\underline{\text { Page }}$

Armer et al. v. Wade et al. . . . . . . . . .

Attorney General ex rel. Wari et al. v. Board of Education of City of Detroit, D.C. Heath and Company $v$. Same . . . . . . . . . .

Audit of Hanover Tp. School District . . . . . . 76 Beard v. Eoard of Education . . . . . . . . . 164

Berkley High School District of Alameda County

v. Coit. . . . . . . . . . . . 143

Betterson v. Stewart . . . . . . . . . 75, 165

Board of iducation of City of Iron Wountain

v. Volker................ 104

Board of Education of Prince George's County

v. County Con'rs. Of Prince George County . . 55

Board of Health of City of Plainfield v. Charles

Simken and Sons, Inc. . . . . . . . . 96

Board of Supervisors of Chesterfield County et

al. v. County s̀chool Board of Chesterfielà

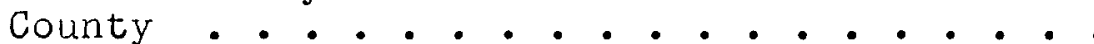

Bozeman et al. v. Lorrow et al. . . . . . . . 171

Buckner v. Board of Education of Owensboro City

school Dist. . . . . . . . . . . 128

Campana v. Calderhead et al. . . . . . . . . 180

Chance et al. v. Nississippi state Textbook

Rating and Purchasing Board et al. . . . . 183

City of Paciucah v. Board of Lducation of Paducah • - 124

Craig et al. v. Bell et al. . . . . . . . . 140

Dickman v. School District No. 62 C, Oregon City . . 183 
Dorothy Whipple Illig et al. v. Town of Plymouth . . 60

Edwards et al. v. State Educational Finance Commission et al. ........... 104

First National Banli of waldron v. Wisenhunt et al. . . 61

Fiscal Court of Logan County v. Board of Education of Logan County............. 124

Flowers v. Independent School Dist. of Tana et al. . 190

Fyfe et al. v. Hardin County Board of Education . . . 124

Goodman v. Jchool District No. I et al. . . . . . 171

Guy Hall v. City of Taft . . . . . . . . . 98

Hayes et al. v. City of Brockton . . . . . . . 59

Hempel v. School bistrict No. $32 y$ of Snohomish County et al.............. 172

Henrietta Indejenuent jchool District v. Garrett and Conpany .............. 123

Hill v. joard of Education of Central School District No. 2 . . . . . . . . . . . .

Howard v. soard of iducation of Harlan Independent school jistrict. . . . . . . . . .

Inciepenciert achool Listrict io. I v. Co.mon achool District fo. 1 et al. . . . . . .... 104

In re Chester School District's Kudit. . . . . . 75

In re German Township School Directors . . . . 76, 163

In re Trenont To. School Directors . . . . . . 77

Insley v. School District No. 2......... 56

Kansas City v. School District of Kansas City . . . . 100

Kentucky Institution for Education of Bind v. City of Louisville . . . . . . . . . 
Leonard et al. v. School Committee of Springfield, et al. . . . . . . . . . . ....

Logan v. Board of Public Instruction of Polk County . 140 Love v. Rockwall Indepencient school District . . . 123 Lowe and Campioli Athletic Gooćs Co. v. Wunn . . . 163 Lowe and Canpbell Athletic loods Co. v. Tangipahoe School Boarc et al............ 164 Lucier v. Town of Norfolk . . . . . . . . . 191 Lyle v. State ex rel smith . . . . . . . . . 190 Marcowitz v. jchool Listrict of Philadelphia . . . . 60 Marshall v. Board of Directors Macedonia School District et al. ............ 191

Martin J. Kaveny v. Buard of Comissioners of the Town of iviontclair........... 96 Mauch Chunk Tp. School Dist. v. Fisher .. . . . 72 McKinney v. soard of Trustees of the Cadiz Graded Common School Dist. . . . . . . . . 126

Morse v. T.wn oi vontville . . . . . . . . . 93

Nelson v. Board of Education of Nilliamsburg . . . 128 Norton v. Tom of Lyersburg . . . . . . . . 126 Opinions of the Justices, Supreme Court of New Hampsire 143 Pasadena School District et al. v. City of Pasadena. . 97 People's Bank of st. Paul v. School Listrict No. 52 . 126 People ex rel schlager v. Reilly Tar and Chemical Corporation ............ . 57

Petition of Auditors of Hatfield $\mathrm{Tp}$. Scnool District 74, 161

Powers et al. v. Jtate Iducational Finance Commission et al. .......... 104

Pullum v. Consolidated School District ivo. 5, Stoddard County ............ 144 
Ralph v. Orleans Parish School Board . . . . . . 171 Rand ifivally and Company v. Royal et al. . . . . 182 Rankin $v$. Board of Eciucation of $\mathrm{E}_{\mathrm{g}} \mathrm{g}$ Harbor Township et al.............. 192

Rigaird v. Board of Bucation of Central school District ivo. 2............ 127

Ring et al. v. Cit $j^{r}$ of voburn .......... 59

Robert H. Smith et al. v. Board of Bducation of the Borough of Denarest........... 94

R.W. Thomas et al. v. L.P. Hollis et al. ...... 105

Salt Lake City v. Soard of Education of Salt Lake City et al.................. 99

Schloke v. Doard of Education of Ft. Thomas. . . . 182 School Board of Last Penn. Tp. School District v. remerer ............ 74

Scott County School Eoard v. Scott County Board of Supervisors ............ 58

Scranton School District Audit . . . . . . 73

Smith et al. v. state Board of Control et al. . . . . 181

Smith v. Board of Eciucation of Pencileton County School District . . . . . . . . . 141

Smith v. Jchool District of Philadelphia et al. . . . 60 Speyer v. School Listrict . . . . . . . . . 172

State Bjaru of Education v. Levit . . . . . . . 181

State ex rel 3rand v. hasted. . . . . . . . . 190

State ex rel Dawson v. Innes et al. . . . . . . 182

State ex rel Frohmiller v. Hencrix . . . . . . 183

State ex rel joore v. killsap........... I80

State ex rel Rice v. Tonpkins.......... 190 
State ex rel Simon v. Fairchild . . . . . . . 180

State ex rel Stewart et al. v. Miller . . . . . 190

Stokley et al. v. Fleming County Board of Education . • 124

Suratt et al. v. Board of Education of City of Ashland ............. . 125

Sylvia Drasin v. Jchool District of Philadelphia . . 60

Taylor et al. v. Loard of Public Instruction of Lafayette Courity . . . . . . . . 142

Tuttle ei al. v. joard of siucation of Sult Lake

City et al.............. 53

Wagner v. Royal et al. . . . . . . . . . 182

Walker v. Joint jchool District iNo. 5, Pown of Alma • 141 Nalling et al. v. valone Indepencient

School District. . . . . . . . . 125

Walters v. State ............ 191

Westland Publishing Co. v. Royal et al. . . . . . 182 